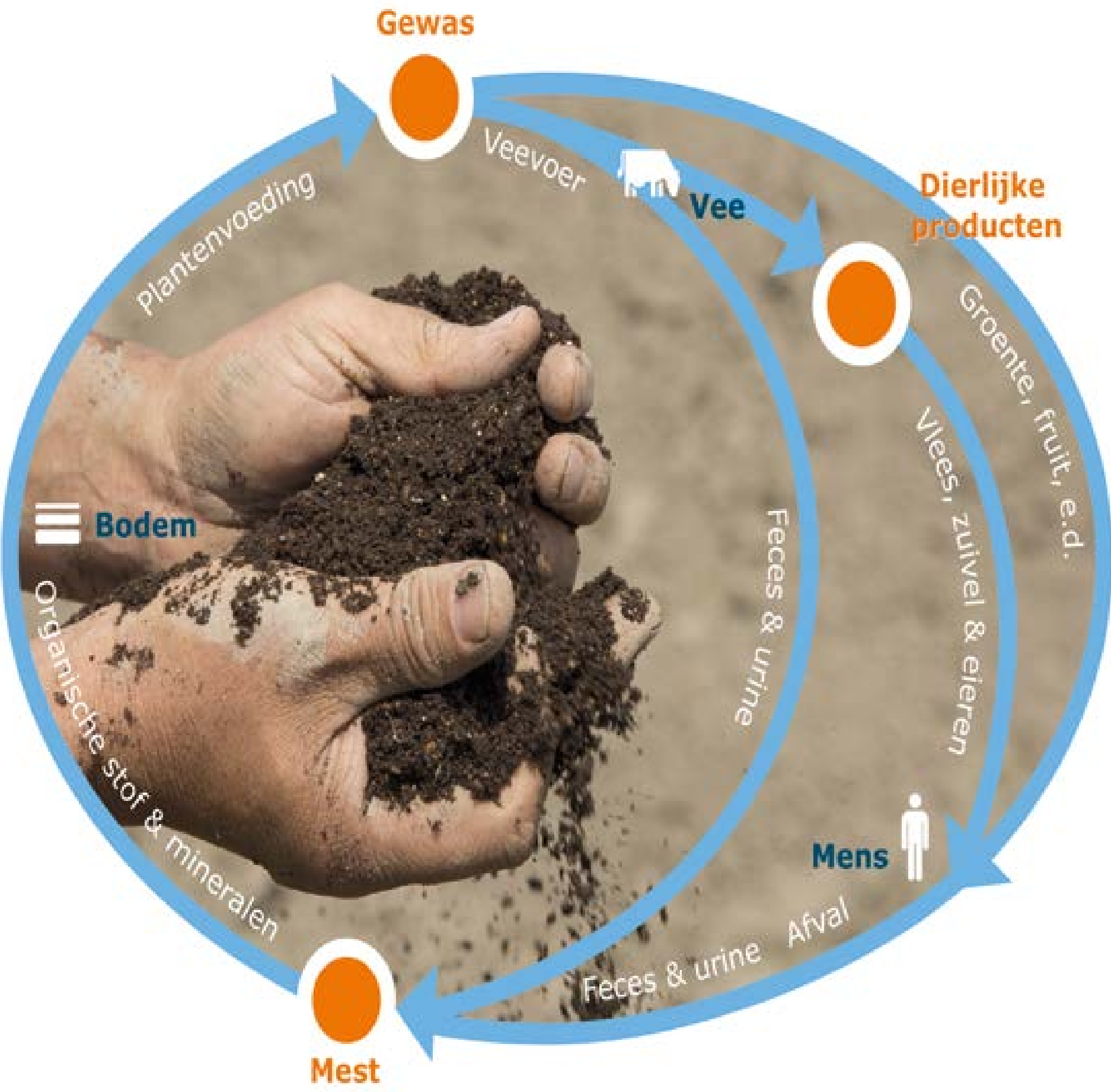

KringloopToets Mestverwerking

Theun Vellinga, Ferry Leenstra, Bart Bremmer, Joost Tersteeg 



\title{
KringloopToets Mestverwerking
}

Vellinga, T.H. ${ }^{1}$, F.R. Leenstra ${ }^{1}$, B. Bremmer ${ }^{2}$, J. Tersteeg $^{3}$

\author{
${ }^{1}$ Wageningen Livestock Research \\ 2 http://innovatiesocioloog.nl/ \\ ${ }^{3}$ Wing, Wageningen
}

Dit onderzoek is uitgevoerd in opdracht van en gefinancierd door de Ministeries van Infrastructuur en Milieu en Economische Zaken en de publiek-private samenwerking (PPS) "Feed4Foodure". Feed4Foodure is medegefinancierd door het Ministerie van Economische Zaken, in het kader van het Beleidsondersteunend Onderzoek (projectnummer BO31.03-005-001).

Wageningen Livestock Research

Wageningen, december 2017 
Theun Vellinga, Ferry Leenstra, Bart Bremmer, Joost Tersteeg, 2017. Kringlooptoets Mestverwerking. Wageningen Livestock Research, Rapport 1046.

\section{Samenvatting NL}

De KringloopToets beoogt nutriëntenstromen in beeld te brengen. Op verzoek van de Ministeries van IenM en EZ (situatie van Kabinet Rutte II) en de Vereniging Diervoederonderzoek Nederland is een KringloopToets uitgevoerd rond het onderwerp mestverwerking. Het bleek dat een situatie die trekkracht veroorzaakt op de markt voor mineralen uit dierlijke mest (er mag in Nederland geen kunstmest gebruikt worden) de deelnemers veel meer uitnodigt tot het gezamenlijk analyseren van de effecten van de maatregel dan een maatregel die 'mestproducten de markt in duwt' (alle varkensmest wordt verplicht verwerkt). Deze rapportage beschrijft de inhoudelijke conclusies en de procesmatige lessen voor uitvoering van de KringloopToets die uit deze casus getrokken kunnen worden.

\section{Summary UK}

The Nutrient Cycle Assessment aims at visualizing nutrient flows. Commissioned by the Ministries of I\&M and Economic Affairs and the Dutch Organisation of Feed Research a Nutrient Cycle Assessment was carried out for manure processing. It appeared that a case with market pull on the market for animal manure (artificial fertilizer is not allowed any more) inspires the participants much more to analyse the effects of such an intervention than when the intervention pushes animal manure in the market (all pig manure has to be processed). This report describes the conclusions of the analysis and the lessons that can be learned from this exercise for future work with the Nutrient Cycle Assessment.

Dit rapport is gratis te downloaden op https://doi.org/10.18174/429966 of op

www.wur.nl/livestock-research (onder Wageningen Livestock Research publicaties).

\section{(C) 2017 Wageningen Livestock Research}

Postbus 338, 6700 AH Wageningen, T 03174839 53, E info.livestockresearch@wur.nl, www.wur.nl/livestock-research. Wageningen Livestock Research is onderdeel van Wageningen University \& Research.

Wageningen Livestock Research aanvaardt geen aansprakelijkheid voor eventuele schade voortvloeiend uit het gebruik van de resultaten van dit onderzoek of de toepassing van de adviezen.

Alle rechten voorbehouden. Niets uit deze uitgave mag worden vermenigvuldigd en/of openbaar gemaakt worden door middel van druk, fotokopie, microfilm of op welke wijze dan ook zonder voorafgaande toestemming van de uitgever of auteur.

De certificering volgens ISO 9001 door DNV onderstreept ons kwaliteitsniveau. Op als onze onderzoeksopdrachten zijn de Algemene Voorwaarden van de Animal Sciences Group van toepassing. Deze zijn gedeponeerd bij de Arrondissementsrechtbank Zwolle. 


\section{Inhoud}

Woord vooraf $\quad 5$

$\begin{array}{ll}\text { Samenvatting } & 7\end{array}$

1

$\begin{array}{ll}\text { Introductie } & 9\end{array}$

1.1 De KringloopToets 9

$\begin{array}{lll}1.2 & \text { Mestverwerking } & 9\end{array}$

$\begin{array}{ll}\text { Werkwijze en maatregelen } & 10\end{array}$

$\begin{array}{lll}2.1 & \text { Algemeen } & 10\end{array}$

2.2 De casus mestverwerking $\quad 11$

2.3 Mogelijke maatregelen 12

2.4 Stakeholders en hun betrokkenheid bij mestverwerking 13

2.5 Beoogde resultaten 14

$\begin{array}{ll}\text { Resultaten } & 16\end{array}$

3.1 Geen gebruik van kunstmest meer $\quad 16$

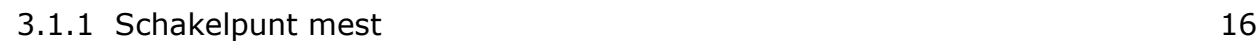

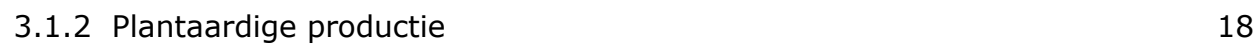

$\begin{array}{ll}3.1 .3 \text { Dierlijke productie } & 19\end{array}$

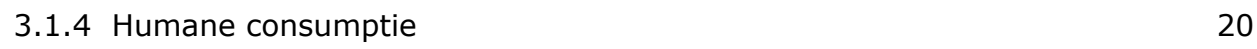

$\begin{array}{ll}3.1 .5 & \text { Schakelpunt plantaardige producten }\end{array}$

$\begin{array}{ll}3.1 .6 & \text { Schakelpunt dierlijke producten }\end{array}$

3.1.7 Betekenis voor circulariteit, beleidsopties en rollen en
handelingsperspectief

3.2 Verplichte verwerking overschotten varkensmest $\quad 22$

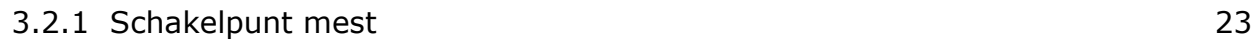

$\begin{array}{ll}3.2 .2 \text { Plantaardige productie } & 24\end{array}$

3.2.3 Dierlijke productie $\quad 25$

3.2.4 Betekenis voor circulariteit, beleid en rollen en handelingsperspectief $\quad 25$

4

$\begin{array}{ll}\text { Conclusies } & 28\end{array}$

$\begin{array}{lll}4.1 & \text { Geen kunstmest } & 28\end{array}$

$\begin{array}{lll}4.2 & \text { Mestverwerking } & 28\end{array}$

$5 \quad$ Bijlagen mbt deelnemers en inhoudelijke informatie 30

5.1 Deelnemers workshop $\quad 30$

5.2 Experts die een bijdrage hebben geleverd 31

$\begin{array}{lll}5.3 & \text { Additionele informatie } & 31\end{array}$

5.4 Dierlijke mest in Nederland $\quad 34$

5.5 Elementen uit beleidsnota Circulariteit 36

5.6 Conclusies van de commissie Nijpels (Toekomst van de Veehouderij) 38

$\begin{array}{lll}5.7 & \text { Biologische landbouw } & 39\end{array}$

5.8 Broeikasgasemissies mestverwerking $\quad 41$

5.9 Kunstmestvervangers en werking $\quad 44$

5.10 Effecten mestbeleid op organische stof $\quad 47$

$\begin{array}{lll}5.11 & \text { Kostprijs en consumenten respons } & 48\end{array}$

5.12 Nationale mineralenbalansen $\quad 50$ 
6.1 Leerpunten voor de KringloopToets $\quad 52$

6.1.1 Het proces gedurende de workshops

6.1.2 'Geen kunstmest' versus 'Mestverwerking' 54

6.2 Mestverwerking en het Prisoners Dilemma $\quad 56$

7

$\begin{array}{ll}\text { Verwijzingen } & 60\end{array}$

Literatuur

61 


\section{Woord vooraf}

Deze rapportage van de KringloopToets Mestverwerking betreft een samenvatting van de discussies en kan niet worden herleid tot de uitspraken van een persoon. Het gaat om inzichten die betrokken partijen helpen om tot een betere besluitvorming te komen over vraagstukken rond mest en mineralen.

Dank aan alle stakeholders (Bijlage 5.1) die hebben meegedaan en regelmatig in staat waren eigen uitgangspunten even overboord te zetten om in het gezamenlijk denkproces verder te komen. We bedanken de experts (Bijlage 5.2) die bereid waren op korte termijn tussen de workshops onderdelen uit te werken en vragen te beantwoorden. Wat wij met hun kennis hebben gedaan is onze verantwoordelijkheid.

De rapportage is aan alle deelnemers voorgelegd en hun opmerkingen zijn in deze finale versie verwerkt. Zij onderschrijven de algemene conclusies uit de rapportage. Dat wil niet zeggen dat iedereen alle detailopmerkingen onderschrijft, maar de conclusies worden wel door iedereen onderschreven. Uiteraard kunnen en willen stakeholders verschillend omgaan met de conclusies, maar dat valt buiten het doel van de KringloopToets. Het bleek, dat sommige deelnemers tijdens de workshops niet al 'hun eieren gelegd hadden' wat betreft de effecten van maatregelen. Bij het becommentariëren van de rapportage kwam dat naar voren. Omdat de opmerkingen na de workshops binnen gekomen zijn en we ze toch aan de rapportage wilden koppelen, hebben we ze in een separate bijlage opgenomen (Bijlage 5.3).

De cases uitgevoerd met de KringloopToets zijn ook een leertraject ter verbetering van de werkwijze. Enkele opvallende leermomenten hebben we in de rapportage in grijs gemarkeerde tekstblokken weergegeven. Bijlage 6.1 geeft een uitgebreidere reflectie op de leerervaringen bij de uitvoering van de KringloopToets Mestverwerking. Deze reflecties zijn geheel voor verantwoording van de auteurs. 


\section{Samenvatting}

Op verzoek van de Ministeries van IenM en EZ (situatie van Kabinet Rutte II) en de Vereniging Diervoederonderzoek Nederland is een KringloopToets uitgevoerd rond het onderwerp mestverwerking. Het bleek dat een situatie die trekkracht veroorzaakt op de markt voor mineralen uit dierlijke mest (er mag in Nederland geen kunstmest gebruikt worden) de deelnemers veel meer uitnodigt tot het gezamenlijk analyseren van de effecten van de maatregel dan een maatregel die 'mestproducten de markt in duwt' (alle varkensmest wordt verplicht verwerkt). Dat betekent nog niet automatisch dat zo'n maatregel bij invoering door iedereen enthousiast omarmd zal worden, maar wel dat een 'vraag' in de markt leidt tot een andere opstelling van deelnemers.

Geen kunstmest meer in Nederland betekent met name schaarste voor stikstof. Naast dierlijke mest zijn ook de humane uitwerpselen nodig om aan het huidige bemestingsniveau te komen en is verdere aanvulling nodig via inzet van klaver en het benutten van spuiwater uit luchtwassers en/of slachtafval. Door de forse import van voedergrondstoffen is er ruim voldoende $\mathrm{P}$ en $\mathrm{K}$ beschikbaar via dierlijke mest om de huidige bemestingssituatie te handhaven. De maatregel 'geen kunstmest' draagt daarom voor $\mathrm{N}$ bij aan circulariteit. De maatregel is een forse stimulans voor mestverwerking, omdat verwerken van de mest noodzakelijk is om de mineralen in de juiste verhouding in de mestproducten te krijgen. De dierlijke mest als geheel bevat te veel P en K t.o.v. de N. De maatregel leidt niet tot overbemesting vanwege wettelijke regelingen; wel waarschijnlijk tot een toename van de organische stof in de bodem. De effecten op emissies zijn mede daardoor lastig te voorspellen. De kunstmestindustrie ziet voor zichzelf wel een rol en kansen in de ontwikkeling van producten uit dierlijke mest en kwaliteitssystemen daarvoor als aanvulling op c.q. vervanging van de huidige kunstmestproducten.

De casus 'alle varkensmest verplicht verwerken' had een heel ander karakter. De maatregel kan een groot scala aan uitkomsten opleveren en daardoor (of door de grote gelijkenis met de huidige situatie?) waren de deelnemers meer bezig met vragen en onzekerheden dan met effecten. Breed onderschreven werd dat marktontwikkeling voor producten van dierlijke mest essentieel is; veel meer dan technische ontwikkeling van de mestverwerking zelf. Voor marktontwikkeling is samenwerking tussen partijen noodzakelijk, evenals een gezamenlijke lange-termijn-investering. Voor optimale mestverwerking moet de veehouderij veranderen en mest als product zien. Voermaatregelen om mineralengehalten in de mest te sturen liggen voor de hand. Radicale veranderingen als gescheiden opvangen van feces en urine in de stal waren voor sommige deelnemers zeker aan de orde, anderen zagen dat als onhaalbaar vanwege de benodigde investeringen. Unaniem was de roep om regie op mestverwerking, zonder dat de deelnemers aangaven wie verantwoordelijk is voor die regie.

De deelnemers waren enthousiast over de toets en met name het open en gericht met elkaar kunnen discussiëren over effecten van een maatregel. De toets leidt tot nieuwe inzichten en meer gezamenlijk begrip. Wat betreft de werkwijze voor de KringloopToets heeft deze ronde inzicht opgeleverd in hoe een maatregel te kiezen en te formuleren. Daarnaast is nog meer aandacht nodig voor het bij elkaar brengen van een complete groep stakeholders, ook als sommige stakeholders niet direct prioriteit aan deelname willen geven. De verwachting is, dat hoe meer de toets bekend wordt, des te gemakkelijker het wordt deelnemers te betrekken. De opzet om tot conclusies te komen op drie niveaus: bijdrage aan circulariteit (visie); welke rollen zijn er voor wie (beleid) en wie kan welke acties ondernemen (handelingsperspectief) voor specifieke partijen lijkt effectief. Het moet echter niet een doel zijn om tot concrete beleidsadviezen te komen. Dat is aan opdrachtgevers en stakeholders voor na de uitvoering van de toets. De toets moet gericht blijven op het delen van inzichten 


\section{$1 \quad$ Introductie}

\section{$1.1 \quad$ De KringloopToets}

De KringloopToets (Vellinga et al., 2016) is een gespreksinstrument waarmee partijen in samenwerking met experts kunnen verkennen hoe nutriëntenstromen in de voer-voedsel-mest kringloop lopen en hoe potentiële (beleids)maatregelen daar op ingrijpen. Een van de doelen van de KringloopToets is het ontwikkelen van gemeenschappelijk taalgebruik en gemeenschappelijk inzicht in feitelijke informatie. De KringloopToets is niet bedoeld om tot een gemeenschappelijke afweging van verschillende aspecten ten opzichte van elkaar te komen. Het instrument is nog in ontwikkeling en voor ontwikkeling worden concrete vraagstukken ingezet.

De KringloopToets beoogt grip te krijgen op de complexiteit van kringlopen en werkt met een actieve inbreng van de betrokken partijen. Een dergelijke participatieve aanpak zorgt ervoor dat partijen met verschillende rollen en belangen een gedeeld beeld krijgen van de effecten van maatregelen om de kringloop te sluiten en de consequenties op verschillende schaalniveaus. Het gaat dan om de richting van de verandering en een indicatie van de omvang ervan voor zowel het sluiten van kringlopen als voor de neveneffecten door de voorgestelde maatregel. Het gedeelde beeld hoeft niet te betekenen dat de betrokken partijen het met elkaar eens zijn over de wenselijkheid van een maatregel. De winst is dat de discussie gevoerd kan worden op basis van heldere argumenten en dat bevorderd wordt dat onderliggende waarden en aannames expliciet worden gemaakt.

De toets kan daarmee een waardevolle bijdrage leveren aan een maatschappelijke en politieke discussie over het sluiten van kringlopen. De toets geeft zelf geen eindoordeel aan, dat is bij uitstek de taak van die maatschappelijke en politieke discussie.

\section{$1.2 \quad$ Mestverwerking}

Nederland heeft een omvangrijke dierlijke productie en importeert daarvoor diervoedergrondstoffen. Een gevolg is, dat in Nederland veel dierlijke mest geproduceerd wordt. De hoeveelheden zijn dusdanig, dat Nederland een overschot heeft aan met name fosfaat in dierlijke mest ten opzichte van de landbouwkundige behoefte van alle gewassen in Nederland. Mestverwerking (het al dan niet na een bewerkingsstap plaatsen van mest buiten de Nederlandse landbouw) wordt door de overheid via een verwerkingsplicht van het mestoverschot als een van de beleidsmaatregelen ingezet om het mestprobleem op te lossen. Andere maatregelen zijn mestdistributie en het verminderen van het mineralengehalte in veevoeders. Meer detailinformatie over de Nederlandse mestproblematiek is beschreven in Bijlage 5.4 .

De meningen in Nederland zijn verdeeld over de wenselijkheid van verschillende vormen van mestverwerking en over de voor- en nadelen daarvan. Daarnaast is er vanuit de wereldwijde schaarste aan nutriënten (en met name fosfor) behoefte aan het recyclen daarvan als een van de onderdelen van een circulaire economie. Dat was aanleiding voor de Ministeries van Infrastructuur en Milieu en van Economische Zaken (situatie van Kabinet Rutte II) en de Nederlandse Vereniging Diervoederonderzoek (via de Publiek Private Samenwerking Feed4Foodure) opdracht te geven de casus Mestverwerking met de KringloopToets te analyseren. 


\section{Werkwijze en maatregelen}

\section{$2.1 \quad$ Algemeen}

De KringloopToets is een gespreksmodel, dat inzichtelijk maakt hoe nutriënten en organische stof zich in voedingsketens bewegen. De KringloopToets gaat uit van een maatregel, die ten opzichte van een referentiesituatie uitgewerkt wordt wat betreft de effecten van die maatregel op verschillende schaalniveaus (bedrijf, regio, land, continent, globaal) voor (de verliezen aan) nutriënten en organische stof en voor andere emissies en economische effecten. Een belangrijk aspect van de KringloopToets is het onderscheid tussen twee typen van processen: enerzijds de primaire processen van productie en consumptie: "dierlijke productie", "plantaardige productie" en "humane consumptie". Dit zijn de bogen in Figuur 1. Anderzijds de zogenoemde secundaire processen in de "schakelpunten" waar voedsel, veevoer, dierlijke producten en mest worden verzameld, verwerkt, verhandeld en getransporteerd. Dit zijn de gestippelde cirkels in Figuur 1. Deze schakelpunten vormen de verbinding tussen de productie- en consumptieprocessen (Vellinga et al., 2016). Bij productie- en consumptieprocessen liggen de mogelijkheden voor verbetering in het efficiënter en/of duurzamer uitvoeren ervan, binnen door de gebruiker gestelde normen en waarden: dingen beter doen. Bij de schakelprocessen liggen de mogelijkheden voor verbetering deels in efficiëntie, maar voor een belangrijk deel ook in het anders verhandelen en transporteren van de producten; hier zijn over het algemeen ingrijpendere veranderingen mogelijk: betere dingen doen.

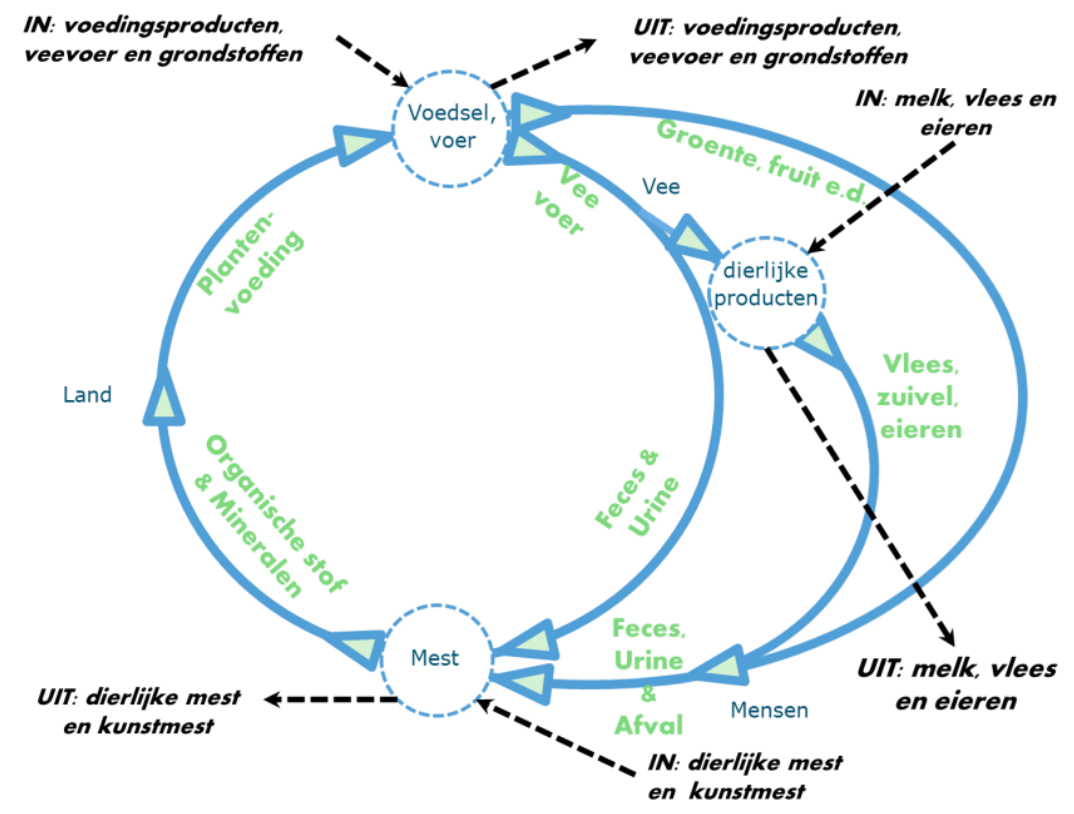

Figuur 1. Schematische weergave van de KringloopToets met de schakelpunten waar de in- en uitvoer van producten plaatsvindt.

In feite gaat het niet om één kringloop maar om heel veel verschillende die onderling met elkaar in verband staan. Elk bedrijf heeft zijn eigen (stukje van de) kringloop en kan stoffen uitwisselen met andere bedrijven, dus met andere kringlopen. Bij elkaar vormen die bedrijven samen ook weer een kringloop, bijvoorbeeld op provinciaal of landelijk niveau. En ook die kringlopen kunnen weer uitwisselen met andere kringlopen, bijvoorbeeld met andere landen. Als het gaat over het (al dan niet) sluiten van kringlopen, kan dat dus op veel verschillende niveaus. (Figuur 2). Omdat in de schakelprocessen de producten overal vandaan gehaald worden en ook weer overal heen gebracht worden, is het belangrijk om verschillende ruimtelijke niveaus te onderscheiden. In de schakelpunten 
kunnen producten en daarmee ook effecten of problemen doorgeschoven worden naar andere gebieden. Op elk ruimtelijk niveau is het kringloopmodel van toepassing.

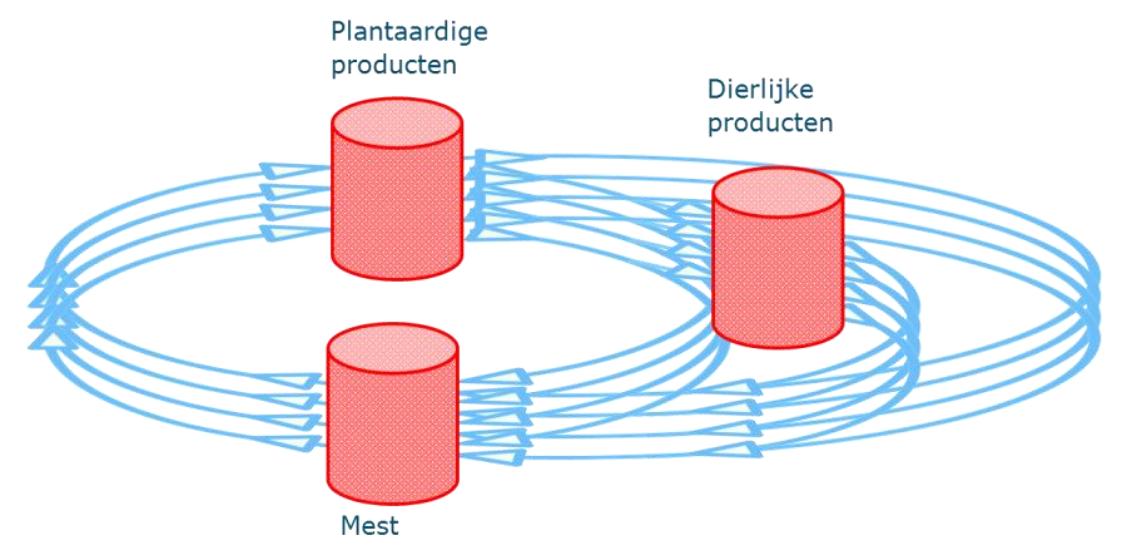

Figuur 2. De meerdere ruimtelijke lagen die aanwezig zijn in kringlopen en die communiceren via de schakelpunten. Elke laag kan worden gezien voor een bedrijf, een regio, een land. In principe zijn (bijna) oneindig veel lagen mogelijk.

De uitvoering van de KringloopToets kan zeer diepgravend en daarmee tijdrovend zijn, maar kan ook op een snelle en dus oppervlakkiger manier worden uitgevoerd. In veel gevallen is een eerste oppervlakkige analyse genoeg om een indruk te hebben van de effectiviteit van een maatregel. Bij het uitvoeren van de toets zijn idealiter alle relevante stakeholders betrokken en kan gebruik gemaakt worden van expertkennis. Welke kennis precies nodig is en welke vragen door experts beantwoord moeten worden, wordt door de stakeholders bepaald tijdens de bijeenkomsten. Hierdoor ontstaat het 'dubbele hamburgermodel': bijeenkomsten met stakeholders waarin vragen worden geformuleerd voor de experts (broodje), worden afgewisseld met bijeenkomsten met experts, die antwoorden op de gestelde vragen formuleren (hamburger). In principe bepalen de stakeholders wanneer voldoende kennis beschikbaar is om tot een eindresultaat te komen en er dus voldoende bijeenkomsten zijn geweest. Uiteraard spelen beschikbare tijd en financiële middelen hierin ook een belangrijke rol. Over het algemeen kan in drie bijeenkomsten met stakeholders tot een eindresultaat gekomen worden.

\subsection{De casus mestverwerking}

$\mathrm{Er}$ is een grote verscheidenheid aan werkwijzen om mest te verwerken met een grote variatie aan eindproducten en hun bestemmingen. Daardoor is het lastig om een overzicht te krijgen en om helder te krijgen wat de gevolgen zijn van mestverwerking op het sluiten van mineralenkringlopen.

Daarnaast is er vaak een verschil van mening over de wenselijkheid van mestverwerking, wat grotendeels samenhangt met het feit dat het mestoverschot slechts één van de aspecten is in het vraagstuk van de veehouderij, het milieu en de volksgezondheid, de beleving van het probleem en de visie op de richting die de landbouw moet volgen.

De ministeries IenM en EZ en andere stakeholders hebben de wens geuit om meer inzicht te krijgen in de consequenties van mestverwerking in relatie tot de nutriëntenkringloop. De nutriëntenkringloop is een van de onderdelen van een circulaire economie. De ontwikkeling van een circulaire economie is een speerpunt in het kabinetsbeleid. Het ministerie van IenM is verantwoordelijk voor de uitwerking daarvan (Ministeries I\&M en EZ 2016, zie Bijlage 5.5 voor een samenvatting) en is op zoek naar handvatten voor een uitwerking in praktische maatregelen.

De Commissie Toekomst Veehouderij (Cie Nijpels) heeft zich onder andere ook over dierlijke mest uitgesproken. Bijlage 5.6 geeft een samenvatting van hun rapportage.

Mestverwerking is als onderdeel van een circulaire economie en als gevoelig en complex onderwerp geschikt om met de KringloopToets aan de orde te stellen. 
Doel:

Het maken van een systematische analyse van (een manier van) mestverwerking om met de verschillende stakeholders een gedeeld inzicht te krijgen in de gevolgen ervan.

\subsection{Mogelijke maatregelen}

De eerste stap betrof het maken van een overzicht van mogelijke manieren om aan het mestvraagstuk te werken. Dat zijn niet persé technische manieren om mest te verwerken; het kunnen ook beleidsrichtingen zijn. Deze maatregelen zijn geplaatst in een raamwerk dat is opgebouwd uit twee assen met kenmerken die belangrijk zijn bij de verschillende scenario's: enerzijds de mate van (extra) ingrijpen via beleid van een (nationale) overheid of sectororganisaties en anderzijds de mate waarin actief wordt gestreefd naar waardecreatie bij mestverwerking.

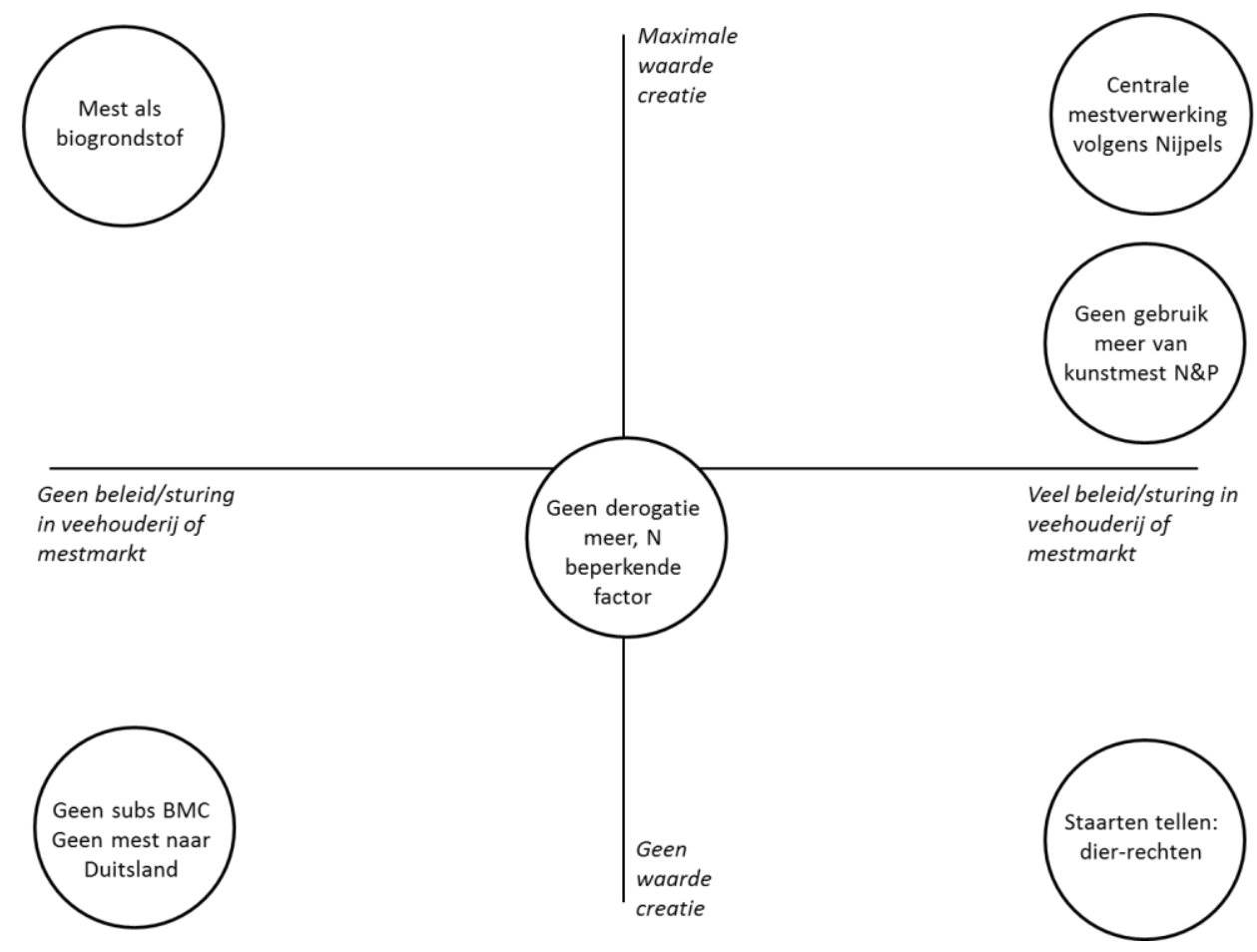

Figuur 3. Zes scenario's/maatregelen die betrekking hebben op mestverwerking in relatie tot de mate van sturing via beleid in de veehouderij of de mestmarkt en in relatie tot de mate waarin actief wordt gestreefd naar waardecreatie.

De mogelijke maatregelen zijn:

- $\quad$ Certificering en centrale organisatie van mestverwerking en mestverwaarding geïnspireerd op het SER rapport over versnelling van verduurzaming (het rapport "Nijpels"). Deze aanpak richt zich op een zo hoog mogelijke waardecreatie met tegelijk een sterke centrale sturing en certificering.

- De tegenhanger wat betreft sturing is de situatie waarbij de waardecreatie geheel aan de markt wordt overgelaten, zonder enige extra sturing door overheden. Dit scenario heeft de naam: "de mest als biogrondstof"

- $\quad$ Een maatregel die niets doet aan waardecreatie, maar die wel een sterk ingrijpen veronderstelt, is het verstrekken van dierrechten of het "staarten tellen", waarbij het aantal dieren zodanig wordt vastgesteld dat er geen overschot is van mest.

- In het kwadrant zonder sturing of inzet op waardecreatie is er een scenario waarbij het verbranden van pluimveemest en het afzetten van gehygiëniseerde varkensmest of digestaat naar Duitsland, niet langer mogelijk is.

Naast de vier min of meer extreme scenario's zijn er nog twee tussenvormen. 
- Het stoppen met gebruik van nutriënten uit kunstmest. Alle mineralen voor bemesting moeten komen uit de dierlijke mest. Dat is qua sturing wel een extreme variant, maar er wordt niet actief ingezet op waardecreatie. Waardecreatie zal wel het gevolg zijn.

Het verliezen van de derogatie die Nederland heeft gevolgen voor de toediening van stikstof. Zonder derogatie wordt $\mathrm{N}$ zeker de beperkende factor in het mestvraagstuk, of te wel het nutriënt met het grootste overschot. Dat zal de behoefte versterken om $\mathrm{N}$ tot waarde te brengen, terwijl de nadruk minder op P komt te liggen. De zes maatregelen/scenario's zijn in onderstaande figuur gerangschikt naar de mate van sturing en de mate van waardecreatie. De respons bij een aantal scenario's kan zijn dat er waardecreatie ontstaat, of dat er een neiging is naar meer sturing, maar dat is dan een gevolg of een ontstane behoefte die geen onderdeel is van de oorspronkelijke maatregel.

\subsection{Stakeholders en hun betrokkenheid bij mestverwerking}

Om tot een werkbare opzet te komen, is samen met de opdrachtgevers een groslijst gemaakt van de actoren bij mestverwerking en de vorm van hun betrokkenheid.

- $\quad$ Centrale overheid, ministeries EZ en I\&M. Deze hebben verschillende verantwoordelijkheden; werken wel samen. De NVWA zorgt voor handhaving namens centrale overheid. Europese Unie, die op grotere afstand kaders schept

- Decentrale overheden: provincie, gemeente, waterschappen, omgevingsdiensten. Zijn vooral betrokken bij de uitvoering van de mestverwerking via verlenen van vergunningen, behandeling van bezwaren en monitoren van de waterkwaliteit

- Veehouderij: producenten van mest. Kijken over het algemeen vanuit een probleem, een overschot

- $\quad$ Akkerbouw, vragers naar mest. Kijken naar de kwaliteit en het voordeel voor hun teelt. $\mathrm{Zij}$ krijgen in veel gevallen betaald voor het accepteren van dierlijke mest; voor hen is er in de huidige situatie dan ook niet direct een probleem

- $\quad$ Biologische boeren, grotere afhankelijkheid van dierlijke mest dan anderen

- $\quad$ Organisaties van landbouwbedrijfsleven. LTO-Noord, ZLTO, maar ook de verschillende deelsectoren worden door LTO en anderen afzonderlijk vertegenwoordigd

- $\quad$ Akkerbouwers in buurlanden: naast de eigen akkerbouwers zijn dat de afnemers van onze verwerkte mest

- $\quad$ Mengvoerindustrie en haar sectororganisatie Nevedi, die via de leverantie van diervoeders direct aan de nutriëntenproblematiek gerelateerd zijn

- $\quad$ Mestverwerkers, de direct uitvoerenden van de mestverwerking

- $\quad$ Leveranciers van technische apparatuur voor mestverwerking

- Industrie en handelaren in organische meststoffen

- Intermediairs in de mestverwerking: loonwerkers, transportbedrijven e.d. en hun brancheorganisatie CUMELA

- $\quad$ Kunstmestindustrie: vanwege de uitwisselbaarheid tussen kunstmest en mest(verwerkingsproducten) en de standaard wat betreft kwaliteitsnormen kunstmest

- $\quad$ Financiers: banken, rijksoverheid, Europese Unie

- $\quad$ Onderzoek: Wageningen UR, RIVM en andere instellingen

- Adviseurs

- $\quad$ Burgerbewegingen: richten zich vaak op bredere overlast

- Omwonenden: komen in actie wanneer mestverwerking in hun directe omgeving dreigt plaats te vinden

- $\quad$ Natuur- en milieuorganisaties. Variatie tussen organisaties, sommigen zien mestverwerking als legitimatie voor intensieve veehouderij en zijn dus tegen. Anderen vinden dat mestafzet goed en veilig geregeld moet zijn

Bij overheden kan verder onderscheid gemaakt worden in:

- Overheden die beleid en regelgeving ontwikkelen om te sturen, maar die niet in de dagelijkse uitvoering zitten. Het gaat dan om de Rijksoverheid en EU. 
- Overheden die in de uitvoering zitten. Dat betreft vooral gemeenten en omgevingsdiensten als het gaat om verlening van vergunningen en behandeling van bezwaren.

- De provinciale overheid en het waterschap zitten in een tussengebied, waar zowel het maken van vooral ruimtelijk beleid als het uitvoeren ervan aan de orde komt.

Uit de groslijst is een selectie gemaakt en zijn de volgende stakeholders uitgenodigd voor deelname:

- Centrale overheid, ministeries EZ en I\&M.

- Decentrale overheden: provincie Noord-Brabant, waterschap Rijn en IJssel

- Veehouderij, LTO Noord.

- Akkerbouw, LTO Noord.

- Mengvoerindustrie: sectororganisatie Nevedi

- Kunstmestindustrie. Yara, ICL.

- Financiers. Banken, rijksoverheid, Europese Unie

- Onderzoek, Wageningen UR, mogelijk andere instellingen

- Adviseurs

- Natuur- en milieuorganisaties: Brabantse Milieu Federatie en Stichting Natuur en Milieu. Uiteindelijk waren de groeperingen 'akkerbouw' en 'financiers' niet vertegenwoordigd en enkele andere minder breed dan gepland. Als reden voor het niet deelnemen werd gebrek aan tijd of vanwege andere activiteiten niet beschikbaar op de data van de workshops genoemd. De deelname van de stakeholders aan de bijeenkomst is beschreven in Bijlage 5.1.

\subsection{Beoogde resultaten}

De opdrachtgevers van de KringloopToets Mestverwerking zijn de ministeries van I\&M en EZ en de Vereniging Diervoederonderzoek Nederland (VDN). De ministeries en de VDN hebben beiden behoefte aan een lange termijn beeld, vanuit hun eigen belang. Daarnaast heeft de VDN behoefte aan concrete handvatten voor de huidige uitvoering van mestverwerking en/of de vermindering van de mestproblematiek. Met de opdrachtgevers zijn daarom drie niveaus geïdentificeerd waar meer zicht op moet komen om tot die concrete handvatten te kunnen komen: het lange termijn doel (stip op de horizon), beleid c.q. opties voor sturing en de rollen van stakeholders en handelingsperspectieven. De KringloopToets moet daarvoor inzicht geven in:

a) De stip op de horizon voor wat betreft circulariteit: De randvoorwaarden waar mestverwerking aan moet voldoen om bij te dragen aan het verbeteren van de kringloop van nutriënten;

b) Beleid en rollen: de beleidsmatige sturing om te zorgen dat de mestverwerking bijdraagt aan het verbeteren van de kringloop van nutriënten en de rol die de verschillende stakeholders moeten vervullen;

c) Het handelingsperspectief: dat sluit aan op de rollen, het gaat nu om de vraag wat partijen moeten en kunnen doen om die rol te vervullen.

In het overleg met de opdrachtgevers bleek, dat de maatregelen, die onderzocht gaan worden, moeten voldoen aan de randvoorwaarde dat actief wordt gezocht naar waardecreatie, het vinden van een nuttige en (financieel) gewaardeerde bestemming van de verwerkte producten. Maatregelen die zich niet op waardecreatie richten lijken geen toekomstperspectief te hebben.

Daarmee is de oorspronkelijke doelstelling van de KringloopToets uitgebreid. De oorspronkelijke doelstelling is het verkennen van de effecten van een interventie of maatregel op het sluiten van kringlopen en bijbehorende neveneffecten. Bij het vraagstuk mestverwerking wordt nu een stap toegevoegd: als de maatregel effectief is, wat betekent dat voor de lange termijn visie, beleid en rollen van stakeholders en voor het handelingsperspectief van verschillende stakeholders. De bovenstaande vragen werden beantwoord door twee cases te kiezen, die beide waardecreatie van mestproducten inhouden. De eerste casus meer gericht vanuit de vraagkant van mest, de tweede meer vanuit het aanbod van mest:

- Het invoeren van een verbod op kunstmest. Er wordt niet gekeken hoe of wie dat organiseert, maar er wordt geen kunstmest meer gebruikt in Nederland. De effecten daarvan worden verkend aan de hand van het schema van de KringloopToets. Deze maatregel wordt verondersteld een stimulans te zijn voor mestverwerking en geeft inzicht in de eerste vraag. 
- $\quad$ De tweede stap is om te kijken naar de hypothetische situatie waarbij alle varkensmest in Nederland, die een varkenshouder niet op het eigen bedrijf kan afzetten, wordt verwerkt.

Deze maatregel geldt alleen voor Nederland; de rest van de EU blijft ongewijzigd.

De huidige situatie met deels verplichte mestverwerking is de referentie. De randvoorwaarden zijn dat a) alle mineralen en organische stof een nuttige aanwending krijgen binnen of buiten de landbouw; b) de verwerking centraal geregeld wordt, alle mest gecertificeerd wordt naar herkomst en samenstelling en c) de neveneffecten voor milieu, economie, en leefomgeving in beeld gebracht zijn.

Figuur 4 geeft de leidraad voor de bijeenkomsten met de stakeholders. In beide gevallen zijn eerst de effecten van de maatregelen in beeld gebracht, later aangevuld met informatie die aan de experts was gevraagd. Aan de hand daarvan is gekeken wat die effecten betekenen voor de stip op de horizon, beleidsrichtingen en rollen en voor het handelingsperspectief van de verschillende partijen.

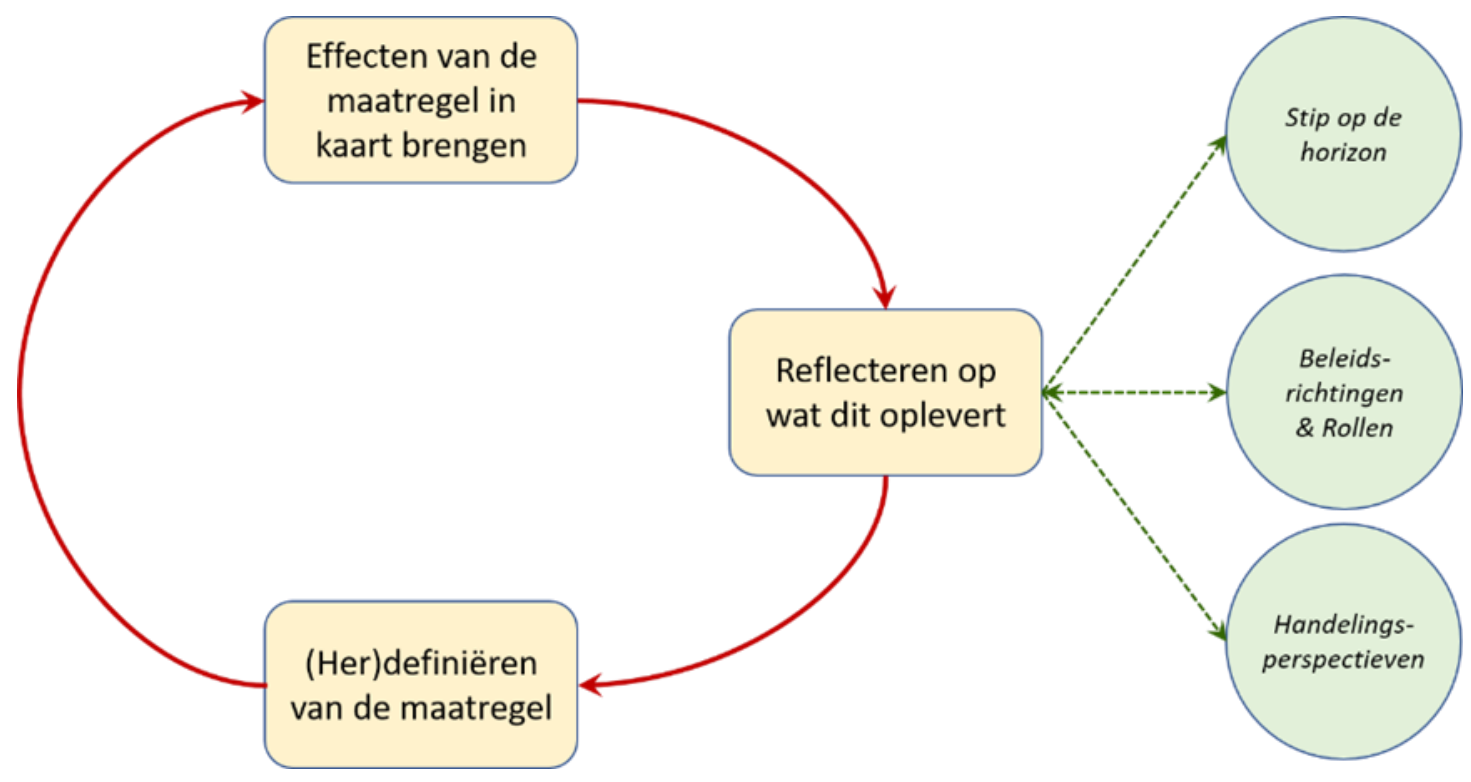

Figuur 4. Schematische leidraad voor de bijeenkomsten met stakeholders. 


\section{Resultaten}

In de workshops kwamen diverse onderwerpen aan de orde die om verdere verdieping vroegen. Experts hebben daarvoor teksten aangeleverd. Deze zijn in bijlagen bij deze rapportage gevoegd. Bijlage 5.7 gaat in op een aantal aspecten rondom biologisch landbouw; Bijlage 5.8 op broeikasgasemissies in relatie tot mestverwerking; Bijlage 5.9 op de werking van kunstmestvervangers en Bijlage 5.10 op de relatie tussen mestbeleid en organisch stof gehalte in de bodem; Bijlage 5.11 gaat in op de relatie tussen kostprijzen en consumentengedrag. Bijlage 5.12 tenslotte geeft nationale mineralenbalansen.

\subsection{Geen gebruik van kunstmest meer}

Deze maatregel grijpt in op de voorziening van mineralen via het schakelpunt mest. De veranderingen in dat schakelpunt worden eerst beschreven, waarna de andere onderdelen van de schematische weergave van de kringloop aan de orde komen (Figuur 5).

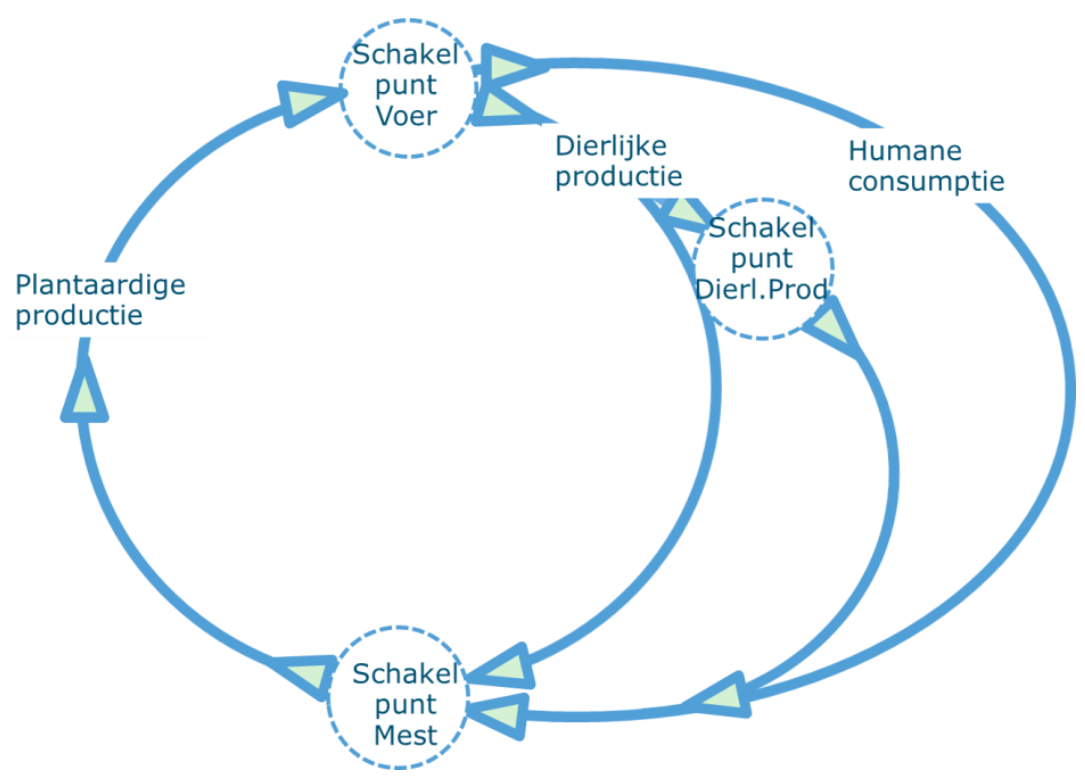

Figuur 5. Schematische weergave van de Kringloop met de drie onderdelen van productie en consumptie en de drie schakelpunten.

\subsubsection{Schakelpunt mest}

Tabel 1 geeft een overzicht van de aanwezigheid aan en het huidige gebruik van mineralen in de Nederlandse landbouw. De meest rechtse groep van drie kolommen, onder het kopje "geen kunstmest" geeft aan of en hoe compensatie voor kunstmest gevonden kan worden. In de tabel is ook "mensenmest" meegenomen, waarbij de benutting van $\mathrm{N}$ gelijk gesteld is aan dierlijke mest. De aanwezige hoeveelheid is bepaald aan de hand van de excretie van mineralen door mens en dier. Het huidige gebruik is bepaald aan de hand van de gebruiksnormen voor $\mathrm{N}$ en $\mathrm{P}$ en van de landbouwkundige bemestingsadviezen voor $\mathrm{K}$.

Door het wegvallen van kunstmest, worden nutriënten schaars: om de productie van gewassen op peil te houden, komt er een herwaardering van mest als leverancier van nutriënten. Dat geldt niet alleen voor de dierlijke mest, maar ook voor de menselijke mest. Dat zorgt voor een sterke stimulans tot mestverwerking, te meer omdat opsplitsen van de mest noodzakelijk is voor een evenwichtige bemesting. De verwachting is dat deze (her)waardering voor mest ook zal leiden tot minder fraude wat betreft mestafzet. 
In de dierlijke mest is voldoende $\mathrm{P}$ en $\mathrm{K}$ aanwezig om geen gebruik te hoeven maken van de menselijke mest (Tabel 1). Er is zelfs nog een overschot van 32 miljoen kg P en 220 miljoen kg K binnen Nederland. De dierlijke mest is echter niet genoeg om het gebruik van kunstmest- $\mathrm{N}$ te compenseren. Daarom moet de $\mathrm{N}$ uit menselijke mest worden gewonnen. Er is uitgegaan van een rendement van twee derde waarmee $\mathrm{N}$ uit mest teruggewonnen kan worden. Dan is er nog niet genoeg $\mathrm{N}$ beschikbaar om de kunstmest- $\mathrm{N}$ te compenseren. Grootschalige inzet van klavers op grasland kan een forse bijdrage leveren aan de $\mathrm{N}$ behoefte. Daarmee moet (en kan) nog 60 kton worden "geproduceerd". Daarnaast zijn spuiwater van luchtwassers en slachtafval genoemd als mogelijke N-bronnen. Deze laatste twee zijn in de berekening nog buiten beschouwing gelaten. Ondanks dat alle dierlijke mest wordt gebruikt om $\mathrm{N}$ te winnen, is er nog steeds een overschot, omdat een deel van de $\mathrm{N}$ niet gewonnen kan worden in de vorm van concentraten en dus als direct werkzame N. Die N komt deels wel in de bodem terecht, maar werkt als organische N pas op langere termijn. Echter, in mengmest van mens en dier zijn de verhoudingen tussen de nutriënten bij lange na niet op maat voor de behoefte van de gewassen. Gemiddeld genomen bevat dierlijke mengmest te veel $\mathrm{P}$ en/of te weinig $\mathrm{N}$ t.o.v. de behoefte van de gewassen en t.o.v. van de gebruiksnormen. In de huidige situatie kan dan met dierlijke mest de behoefte van slechts één van de nutriënten goed worden gedekt en is de dekking van de andere suboptimaal. Ook is op nationaal niveau de noodzaak tot terugwinning van N, P en $\mathrm{K}$ voor binnenlands gebruik verschillend (Tabel 1 ). Daarom is een vorm van mestverwerking nodig waarmee $\mathrm{N}$, $\mathrm{P}$ en $\mathrm{K}$ los van elkaar gewonnen kunnen worden. De overschotten ( $P$ en ook $K$ ) kunnen/moeten dan worden geëxporteerd, de $N$ kan volledig worden ingezet in Nederland. De huidige koppeling tussen $\mathrm{N}$ en $\mathrm{K}$ in concentraten kan nog leiden tot te hoge $\mathrm{K}$ giften als alle $\mathrm{N}$-behoefte uit dergelijke concentraten gedekt zou worden.

\section{Handelingsperspectief}

De sector mestverwerking zal zich dus richten op differentiatie in producten: $\mathrm{N}$ en organische stof moeten in Nederland blijven; een overschot aan P en K-blijft bestaan en moet buiten Nederland worden afgezet. Door de waardering van de mest zal de mestverwerking minder afhankelijk worden van subsidies en zullen poorttarieven (de prijs die de leverancier van mest moet betalen aan de verwerker) dalen. Door de afhankelijkheid van de dierlijke mest en producten daarvan, zal er een sterke aandacht komen voor kwaliteit: de controleerbaarheid van gehalten en de werkingscoëfficiënten van de $\mathrm{N}$ - en K-concentraten. Er zal vraag ontstaan naar een systeem van certificering van de mest waarmee de gehaltes en de werkingscoëfficiënten van mestproducten gegarandeerd worden. Zowel voor constante kwaliteit als voor certificering heeft een zekere schaalgrootte bij de mestverwerking voordelen. Indien de producten van mestverwerking stabiel en constant zijn wat betreft samenstelling en hoeveelheden worden ze aantrekkelijk als grondstof voor de kunstmestindustrie, die zeker een rol kan spelen in de kwaliteitsbewaking, zij hebben daar ervaring mee. Het gebruiken van de producten uit mestverwerking als grondstof voor kunstmestproducten is een logische volgende stap, zeker voor de export van P- en K-meststoffen.

Tabel 1 De beschikbaarheid van N, P (zuiver, niet P205) en $K$ in dierlijke en menselijke mest, het huidige gebruik en de opties om het kunstmestgebruik te compenseren met nutriënten uit dierlijke mest, menselijke mest en klaver, alles in Mkg/jaar. (Bronnen: divers, plaatsingsruimte op grond van aantal ha landbouwgrond $x$ gemiddeld voor Nederland toegelaten bemesting aan $N$ en $P$ ).

\begin{tabular}{|c|c|c|c|c|c|c|c|c|c|}
\hline & \multicolumn{3}{|c|}{ Aanwezig } & \multicolumn{3}{|c|}{ Huidig gebruik } & \multicolumn{3}{|c|}{ Geen kunstmest } \\
\hline Dierlijke mest & 500 & 72 & 500 & 340 & 54 & 340 & 340 & 54 & 340 \\
\hline Extra uit dierlijke mest & & & & & & & $110 *$ & 4 & 30 \\
\hline Humane mest & 90 & 18 & 90 & & & & $60 *$ & & \\
\hline Totaal & 590 & 90 & 590 & 572 & 58 & 367 & 570 & 58 & 370 \\
\hline Overschot t.o.v. aanwezig & & & & 250 & 36 & 250 & $\mathbf{8 0} * *$ & 32 & 220 \\
\hline
\end{tabular}

*: beschikbaar aan $\mathrm{N}$ uit dierlijke en humane mest resp. 500-340=160 en $90 ; 60 \%$ daarvan om met tot kunstmest vergelijkbare bemestende waarde te komen.

**: de $\mathrm{N}$ die niet werkzaam is en mogelijk verloren gaat, wordt hier nog als overschot beschouwd. 


\section{Neveneffecten}

De verwachting is dat het transport van onverwerkte mest en verwerkingsproducten in Nederland toe zal nemen, omdat grootschalige verwerking waarschijnlijk noodzakelijk is. Dat kan een stimulans betekenen voor het ontwikkelen van simpele mestscheidingstechnieken op het veehouderijbedrijf, of van rioleringssystemen om transport over de weg van grote hoeveelheden water te voorkomen. De export van dierlijke mest uit Nederland en daarmee internationaal transport van mest zal afnemen.

Vanwege de schaarste aan $\mathrm{N}$ zal er ook een stimulans zijn tot het gebruik van andere vormen van biomassa.

De verwerking van de mest zal niet zorgen voor een grotere beschikbaarheid aan meststoffen voor de biologische landbouw, de oorsprong van veel verwerkingsproducten is nog steeds van niet biologische productiewijzen.

De verschuiving van kunstmestproducten naar concentraten en andere producten uit dierlijke mest kan gevolgen hebben voor de uitstoot van broeikasgassen. Het effect is echter afhankelijk van twee factoren:

- $\quad$ De gewasopbrengst in de nieuwe situatie. De verwachting is dat opbrengst niet of nauwelijks zal dalen en dat ook de kwaliteit weinig wordt beïnvloed. Als onverhoopt wel sprake is van opbrengstdaling via minder beschikbare werkzame $\mathrm{N}$ zal de emissie per kg product (ruwvoer en akkerbouwproducten) wel iets lager zijn. Het leidt dan tot meer landgebruik, deels ook buiten Nederland. Als het eiwitgehalte van het ruwvoer afneemt, zal aanvulling van eiwit moeten plaatsvinden. De aanvoer van eiwitrijke grondstoffen kan toenemen. Dat zijn producten met een relatief hoge broeikasgasemissies per kg product. Deze aanvulling zal leiden tot een iets hogere beschikbaarheid van $\mathrm{N}$ in Nederland.

- $\quad$ Er is nog weinig bekend over de emissies van de mestverwerking in vergelijking tot de emissies van kunstmestproductie. De emissies van kunstmest $\mathrm{N}$ zijn dalende door het afvangen van lachgas bij de omzetting van ammoniak naar nitraat. Het drogen van mest vergt erg veel energie. De emissies van transport leveren slechts een beperkte bijdrage. Het is daarom niet meteen te zeggen dat de emissies van de nieuwe te produceren meststoffen lager zullen zijn. Veel hangt af van de productiewijze en in mindere mate de transportsystemen.

\subsubsection{Plantaardige productie}

In de huidige situatie wordt relatief veel kunstmest- $\mathrm{N}$ gebruikt in Nederland, zowel in de akkerbouw als in de veehouderij (op grasland, zie ook de derogatie). De verwachting is dat het gemis van kunstmest volledig kan worden opgevangen door een combinatie van bronnen. Voor $\mathrm{P}$ en $\mathrm{K}$ is die compensatie mogelijk door gebruik te maken van alleen dierlijke mest.

Er zijn twee voorwaarden voor het op peil kunnen houden van de plantaardige productie:

- $\quad$ De nutriënten N, P en K moeten onafhankelijk van elkaar kunnen worden gedoseerd, dus niet meer gebonden aan de vaste verhoudingen waarin ze in de mest voorkomen.

- $\quad$ De werking van de $\mathrm{N}$ uit de concentraten moet vergelijkbaar zijn met die van kunstmest. De $\mathrm{N}$ uit de huidige $\mathrm{N}$-concentraten is beter werkzaam dan de $\mathrm{N}$ uit de ruwe dierlijke mest, maar minder goed dan de $\mathrm{N}$ uit kunstmest. De werking van de concentraten kan mogelijk worden verbeterd door de gehalten aan organisch-gebonden $\mathrm{N}$ en aan $\mathrm{C}$ te verlagen. Echter, de werking van concentraten in het veld is nog niet goed voorspelbaar. Als concentraten worden gebruikt in plaats van dierlijke mest, zal wel minder $\mathrm{N}$ nodig zijn om hetzelfde effect te bereiken, als concentraten dienen om de kunstmest te vervangen zal de opbrengst iets kunnen dalen omdat de maximale $\mathrm{N}$ toediening (benutbaar en niet-benutbaar gezamenlijk) is beperkt. Bij verbetering van de concentraten zal het verschil met kunstmest kleiner worden en wordt geen opbrengstvermindering meer verwacht. Dan zullen ook de emissies naar water en lucht niet toenemen t.o.v. de kunstmest-situatie.

- $\quad$ Als een deel van de $\mathrm{N}$ wordt toegediend in organische vorm, zal deze niet direct werkzaam zijn, maar op langere termijn wel. De aanvoer van organische stof neemt dan toe, wat leidt tot een hoger organische stof gehalte in de bodem. Dit kan leiden tot een beter bodemleven en minder uitspoeling, echter harde gegevens hierover ontbreken nog. Tegelijkertijd is de werking van de toegediende $\mathrm{N}$ mogelijk minder goed door mineralisatie op minder gunstige momenten, waardoor de kans op met name uitspoeling juist kan toenemen. 
De toepassing van verwerkte mestproducten zal niet leiden tot overschrijding van de bemestingsnormen; dat is wettelijk geregeld.

\section{Handelingsperspectief}

Met name de akkerbouwer zal zich moeten aanpassen. Tot nu toe had de akkerbouw een riante positie op de mestmarkt en kreeg geld toe bij het afnemen van dierlijke mest. Dat verandert sterk: nutriënten wordt schaars, het alternatief van kunstmest verdwijnt.

Het zou kunnen dat het verbod op kunstmest boeren zal stimuleren om over te schakelen op biologische teelt. Deze stimulans zal het sterkst zijn in de akkerbouw en in de melkveehouderij, maar bij beide in bescheiden mate. In de intensieve veehouderij is die stimulans nauwelijks aanwezig, omdat daar het grootste deel van het voer uit het buitenland komt. Voor de akkerbouw geldt dat het aanpassen van het bouwplan en het dan moeten stoppen met het gebruik van diverse gewasbeschermingsmiddelen grotere belemmeringen zijn dan de veranderingen met betrekking tot kunstmest. Daarnaast moet mest conform de voorwaarden voor biologische teelt beschikbaar zijn uit de veehouderij en daarvoor moet ook de veehouderij omschakelen naar biologische productie. Daarom wordt een beperkte groei van het aanbod van biologische akkerbouw- en zuivelproducten verwacht.

\section{Neveneffecten}

De verwachting is geuit dat door andere bemesting en de mogelijk betere voorziening met organische stof de weerbaarheid van gewassen zal toenemen met mogelijk lagere toediening van gewasbeschermingsmiddelen.

De kostprijs van plantaardige producten kan door de maatregel veranderen: in plaats van geld te ontvangen voor het gebruiken van dierlijke mest, zal de akkerbouwer moeten betalen voor de mest en daarvan afgeleide producten. Anderszins is de aankoop van kunstmest niet meer mogelijk. De verwachting is, dat de kostprijs van akkerbouwproducten omhoog gaat. Veel van de akkerbouwproducten worden op de wereldmarkt afgezet (aardappelen, uien, voedergranen, suiker). Het wordt dan lastig de hogere kostprijs aan consumenten door te berekenen. Daarmee kan de maatregel de inkomens van akkerbouwers negatief beïnvloeden. Het kan ook leiden tot afname van het areaal akkerbouwgewassen ten koste van de melkveehouderij, die grond nodig heeft (en dat beter kan betalen) voor iets minder optimale voerproductie.

\subsubsection{Dierlijke productie}

De stimulans om de $\mathrm{N}$ excretie in mest te verlagen zal verminderen. Doordat $\mathrm{N}$ schaars is, zal er juist behoefte zijn aan $\mathrm{N}$ uit dierlijke mest.De verwachting is dat het aantal biologische veehouders niet sterk zal toenemen. Er is al een opnamestop om overaanbod van biologische melk te voorkomen. Ook zijn de strengere eisen aan beweiding en het aankopen van biologisch krachtvoer belangrijke belemmeringen. In de intensive veehouderij (varkens, pluimvee) zal de stimulans tot overschakeling naar biologische landbouw erg klein zijn. De beschikbaarheid van biologische grondstoffen voor veevoer en het beschikbaar moeten hebben van de uitloop zijn belangrijke beperkingen.

\section{Neveneffecten}

De effecten op de kostprijs van melk zijn lastig aan te geven, vanwege het niet meer mogen toepassen van kunstmest. Mogelijk stijgen de bemestingskosten, ondanks het niet meer aankopen van kunstmest, vanwege de noodzaak tot mestbewerking, of dalen de gewasopbrengsten enigszins. Melkveebedrijven met nu een mestoverschot krijgen te maken met dalende mestafzetkosten, afhankelijk van de toekomstige bemestingsnormen voor N. De kostprijs is voor zuivel belangrijk, omdat de sector afhankelijk is van de export en dus van de wereldmarktprijs. Doorberekenen van een kostprijsstijging aan de Nederlandse consument biedt weinig soelaas. Als de kostprijs toeneemt, heeft dat effect op inkomens van melkveehouders.

Door de prijsveranderingen voor mest zal de kostprijs van de intensieve veehouderij dalen. De prijs van Nederlands veevoer stijgt waarschijnlijk, maar de prijs van geïmporteerd veevoer blijft gelijk. 


\subsubsection{Humane consumptie}

De prijsstijgingen voor plantaardige producten en mogelijke prijsveranderingen in dierlijke producten zullen waarschijnlijk weinig effect hebben op consumptie in Nederland en de belangrijkste landen waar Nederland dierlijke producten naar exporteert. Momenteel is voedsel in Nederland relatief goedkoop en wordt niet verwacht dat door de maatregel de consumentenprijsverhoudingen tussen Nederlandse en geïmporteerde producten significant veranderen.

Volgens Hoste (2017, http://edepot.wur.nl/412970) voor varkens en van Horne (2017, http://edepot.wur.nl/404949) voor pluimveevlees heeft een beperkte kostprijsstijging geen enkel effect op de prijsvorming op de korte termijn. In een studie voor de autoriteit consument en markt (ACM) in 2014 blijkt hoe prijzen in de keten tot stand komen (https://www.acm.nl/nl/zoekresultaat/?zf[]=qu\%3Aprijsvorming\%20voedsel\%202014 ).

\subsubsection{Schakelpunt plantaardige producten}

De effecten op de opbrengst en kwaliteit van de plantaardige productie in Nederland zullen zeer beperkt zijn. Daarmee zal ook de invloed op de import van veevoer en andere producten beperkt zijn. Als de binnenlandse productie toch lager wordt door de maatregel zal de import van grondstoffen voor veevoer (en mogelijk humane consumptie) kunnen toenemen. Daarmee stijgt met name het $\mathrm{P}$ overschot.

Er bestaat een kans dat extra $\mathrm{N}$ rijke (veevoer)grondstoffen geïmporteerd gaan worden, als het niet lukt de eiwitproductie voor met name de melkveehouderij uit eigen voerproductie op peil te houden. Daarbij kan, afhankelijk van de uiteindelijke eiwitvoorziening, ook de totale melkproductie in Nederland beïnvloed worden

De kostprijs van plantaardige producten in Nederland zal stijgen. Dat wordt veroorzaakt door de prijsstijging van mest en daarvan afgeleide producten. Vrijwel alle producten die in Nederland geproduceerd worden hebben de Europese Unie als afzetmarkt en soms zelfs breder, namelijk de wereldmarkt (bijvoorbeeld aardappelen, voedergranen en uien). Met die hogere kostprijzen wordt lucratieve afzet op de wereldmarkt lastiger, maar de concurrentiepositie van veel gewassen zoals aardappelen, uien en suikerbieten is positief t.o.v. het buitenland. Het gevolg zal zijn dat de akkerbouwers iets minder inkomen hebben maar niet dat de productie zal dalen. Een sterke aanwijzing dat de concurrentiepositie van de Nederlandse akkerbouwers (en veehouders) goed is betreft de prijzen die ondernemers bereid zijn te betalen voor grond en productierechten (http://www.boerderij.nl/landbouwgrond/grondprijzen/?gebied=2507\#pricescontent ).

\subsubsection{Schakelpunt dierlijke producten}

In de Nederlandse intensieve veehouderij blijft ruimte voor 'bulkproductie' (lees: productie met een pure kostprijsoriëntatie). Dit laat onverlet dat deze productie zich ontwikkelt als gevolg van verschillende maatschappelijke ontwikkelingen. Legbatterijen zijn afgeschaft, verantwoorde (RTRS) soja is ingevoerd (http://www.responsiblesoy.org/?lang=en), de Kip van Morgen, en het Varken van Morgen zijn geïntroduceerd in de markt. Dit zijn op de wereldmarkt nicheproducten maar kunnen de bulkproducten van de toekomst gaan vormen, gegeven de ontwikkelingen wat betreft dierenwelzijn wereldwijd. In Nederland is maximaal zo'n 30\% van de markt voor producten met een specifieke marktoriëntatie (biologisch, milieuvriendelijk, diervriendelijk, lokaal geproduceerd, etc.). Of "kunstmestvrij" op zich in de vermarkting meerwaarde heeft is de vraag. Ca. twee derde van de in Nederland geproduceerde producten wordt in het buitenland afgezet, terwijl de Nederlandse retail en voedingsindustrie ook dierlijke producten uit het buitenland inkopen. Bijvoorbeeld de productie van varkensvlees in Nederland is 1.3 miljoen ton in 2014, er wordt 0.3 miljoen ton vlees geïmporteerd, 0.9 miljoen ton vlees geëxporteerd en 0.7 miljoen ton vlees geconsumeerd (zie http://www.agrifoodnieuws.nl/bestanden/agrifoodnieuws/nwsbrf30/2016013_Baltussen_DEF_20160125.pdf figuur 1.3).

Door de kostprijsverlaging in met name de intensieve veehouderij vanwege dalende kosten voor mestafzet kan de exportpositie van varkens- en pluimveevlees worden versterkt. Daarmee heeft de 
maatregel "geen kunstmest" geen invloed op de omvang van de intensief gehouden veestapel. Bij de melkveehouderij zou er sprake kunnen zijn van een lichte krimp.

Afhankelijk van de effecten op de kostprijs van melk, kan de export worden beïnvloed.

\subsubsection{Betekenis voor circulariteit, beleidsopties en rollen en handelingsperspectief}

In het voorgaande is in beeld gebracht wat de maatregel betekent voor stofstromen en wat de neveneffecten zijn. In deze paragraaf wordt beschreven wat deze effecten mogelijk betekenen voor de bijdrage aan het sluiten van kringlopen, welke beleidsopties en rollen er zijn en wat het handelingsperspectief is voor de verschillende stakeholders.

Circulariteit

- De verwachting is dat de kringloop van $\mathrm{N}$ beter wordt gesloten door de schaarste. Er zal meer aandacht zijn voor terugwinning en efficiënte inzet van de schaarse inputs.

- $\quad$ De werkingscoëfficiënten van concentraten zijn momenteel duidelijk lager dan van kunstmestkorrels en iets lager dan die van vloeibare kunstmest. In combinatie met andere vormen van bemesting kan dat mogelijk leiden tot meer verliezen van $\mathrm{N}$.

- $\quad$ Op het gebied van $\mathrm{P}$ en $\mathrm{K}$ ontstaat in dit scenario geen verhoogde circulariteit. Het overschot aan $\mathrm{P}$ en $\mathrm{K}$ in dierlijke mest blijft bestaan.

- De vervanging van de kunstmest is alleen mogelijk dankzij de grote invoer van nutriënten via plantaardige grondstoffen voor humane en dierlijke voeding. In dat deel van de voedselketen (het elders verbouwen van geïmporteerde plantaardige grondstoffen) is nog steeds geen sprake van circulariteit. Het stoppen met kunstmest stuurt daar niet op.

\section{Verplaatsen van het probleem?}

Door de grote invoer van nutriënten via grondstoffen wordt op internationale schaal de circulariteit doorbroken. Deze nutriënten keren niet terug naar gebieden waar ze zijn onttrokken. Dat hoeft ook niet één-op-één te gebeuren, ook inzet van deze nutriënten in andere gebieden kan uit oogpunt van nutriëntenkringlopen al zinvol zijn. Door meer nutriënten uit mest in eigen land te benutten, wordt minder dierlijke mest geëxporteerd en zal in andere landen een extra aanvulling met kunstmest moeten plaatsvinden.

De verbetering van de circulariteit zit dan vooral in de (kunstmatige) creatie van schaarste, die een stimulans is om de benutting van nutriënten uit dierlijke mest zo hoog mogelijk te maken. Dat uit zich met name in een betere benutting van de $\mathrm{N}$ uit de dierlijke mest door de productie van concentraten en in de scheiding van N, P en K zodat de bemesting op maat gerealiseerd kan worden. De daarvoor ontwikkelde technologie kan ook elders ter wereld ingezet worden. Dan kan wel sprake zijn van verbeterde circulariteit van nutriënten.

\section{Beleidsopties en rollen.}

- De casus ligt in lijn met wat de LTO Melkveehouderij nu voorstelt m.b.t. kunstmest $\mathrm{N}$ : geen $\mathrm{N}$ uit kunstmest meer gebruiken.

- De nitraatrichtlijn stelt expliciet maxima aan $\mathrm{N}$ hoeveelheid uit dierlijke mest per hectare en impliciet ook grenzen aan de toediening van kunstmest. De regelgeving is gebaseerd op de maximaal toelaatbare nitraatgehaltes in het grondwater. Als andere $\mathrm{N}$-bronnen (inclusief vlinderbloemigen) worden gebruikt, heeft dat invloed op de nitraatgehaltes in het water. Afhankelijk van de status van de concentraten kan in de toepassing daarvan spanning zitten, vanwege de lagere werkingscoëfficiënt van de $\mathrm{N}$ uit concentraten. Oplossing daarvoor kan in regelgeving gevonden worden.

- Gegeven de geopolitiek en de schaarste aan te mijnen fosfaat is er behoefte ook op P schaarste te sturen. Het uitmijnen van geologische voorraden (en via import van voedings- en voedergrondstoffen andere landen) kan niet blijven voortduren. Omdat Nederland nauwelijks P-kunstmest gebruikt, verandert in deze casus niets aan deze situatie.

- De omwenteling naar grootschalige mestverwerking en eventueel verwerken van humane mest vergt grote investeringen in de infrastructuur (fabrieken, maar vooral opslag van ruwe en verwerkte producten, e.d.). De verwachting is dat de industrie niet in zijn eentje deze investeringen gaat doen; daarvoor is ketenvorming en ondersteuning van de overheid nodig. 
- Door de verandering in de omgang met mest zou Nederland een koploperspositie kunnen innemen, en daarmee internationaal kennisleverancier kunnen worden op dit gebied.

\section{Handelingsperspectief}

- Akkerbouw en veehouderij zullen zoeken naar productdifferentiatie, de omschakeling naar biologische productie biedt op korte termijn zeer beperkt perspectief.

- De intermediairs krijgen een sterkere rol in bedienen van een binnenlandse markt voor $\mathrm{N}$ en K.

- $\quad$ De mestverwerking zal sterk worden gestimuleerd.

\subsection{Verplichte verwerking overschotten varkensmest}

De tweede casus, die gebruikt werd om aspecten van mestverwerking te onderzoeken, was: alle varkensmest, die niet op eigen bedrijf geplaatst kan worden, wordt verplicht verwerkt. Omdat pluimveemest in Nederland al vrijwel volledig verwerkt wordt en de meeste melkveebedrijven een groot deel van de mest op eigen bedrijf kunnen plaatsen, ontstaat een overzichtelijke maar toch realistische casus. Vanwege de verplichte mestverwerking zullen nieuwe bemestingsproducten ontstaan. In deze casus zijn alle grondgebruikers (akkerbouw en voederteelt voor rundvee) vrij in het kiezen van meststoffen, binnen de geldende regelgeving.

Verplichte verwerking van alle varkensmest bleek in de workshop te algemeen en in de analyse liep men meteen aan tegen twee essentiële vragen: a) hoe organiseer je de ontwikkeling van de (internationale) markt voor verwerkte producten en b) hoe organiseer je de samenwerking in de keten. Marktontwikkeling kost veel tijd en geld en vergt een gezamenlijke inspanning.

\section{Vraag-gestuurd of aanbod-gestuurd}

De twee maatregelen die zijn geanalyseerd in deze workshops hebben elk een verschillend karakter.

De casus "geen kunstmest" creëert een duidelijke vraag naar nutriënten. De analyse die de deelnemers ontwikkelen richt zich op de veranderingen die zullen of kunnen optreden in productie, in kostprijs, maar ook in rollen van partijen. Uiteraard is dat allemaal omgeven met onzekerheden, maar er is wel een duidelijke richting. Er ontstaat een zekere vorm van verdere optimalisatie van de nutriëntenbenutting.

De casus "verwerking overschot varkensmest" gaat niet uit van een vraag, maar vanuit het probleem dat varkenshouders hun mest kwijt moeten. Het is een afval product dat (uiteraard) wel netjes verwerkt moet worden. De analyse van deze casus werd overheerst door de vragen over hoe de markt voor verwerkingsproducten ontwikkeld kan worden en over hoe je de daarvoor noodzakelijke samenwerking organiseert. Een inhoudelijke analyse over de effecten op de verandering van stofstromen in en buiten Nederland kwam weinig aan bod. Voor een deel is dat verklaarbaar omdat het overlap vertoont met de casus "geen kunstmest". Voor een ander deel is de verklaring waarschijnlijk dat "mestverwerking" een aanbod-gestuurde benadering is. Door de aanbodsturing gaan betrokken actoren naar elkaar kijken wie nu de eerste stap zet in de hoop daarvan zelf ook te kunnen profiteren. Tegelijkertijd worden tekortkomingen bij overheden als argument gebruikt om te blijven afwachten.

De kern van de aanpak van mestverwerking is in onze ogen dat allereerst een markt gemaakt moet worden voor (bewerkte/verwerkte) meststoffen en organische stof binnen en buiten Nederland. Er moet aan producten van dierlijke mest getrokken worden, in plaats van het in de keten duwen van dierlijke mest. Dat kan door marktontwikkeling, maar de casus "geen kunstmest" leert dat ook kunstmatige ingrepen kunnen zorgen voor het ontstaan van een vraag naar mestproducten. 
Naast deze twee grote vragen kwamen nog andere aspecten van mestverwerking aan de orde, zoals de logistiek/transport, de technische organisatie van de verwerking, kostentoerekening en risico's voor volksgezondheid en veiligheid. Verder vereist mestverwerking niet alleen een technische aanpak aan de "achterzijde", maar moet ook eerder in de productieketen worden ingegrepen: de diervoeding beïnvloedt de kwaliteit van de mest, stalsystemen beïnvloeden de vorm van de mest. Hoewel organische stof een belangrijke rol vervult in bodemkwaliteit en -vruchtbaarheid, moet worden gewaakt voor te hoog gespannen verwachtingen.

\subsubsection{Schakelpunt mest}

In de schakelpunten van plantaardige en dierlijke producten zijn in de workshop geen effecten benoemd. In het schakelpunt mest gebeurt dusdanig veel dat daar een onderverdeling is gemaakt.

\section{Marktontwikkeling en samenwerking tussen partijen}

Alle partijen zijn het er over eens dat de markt voor mestproducten een potentieel aantrekkelijke markt is, maar dat deze markt dan wel eerst ontwikkeld dient te worden. Diverse bedrijven en enkele samenwerkingsverbanden zijn op dit moment bezig met het verwerken van mest en het vermarkten van de producten die daaruit voortkomen. Sommigen zijn daarin heel succesvol, maar voor de meerderheid is dit nog een zoektocht. Op technisch vlak maar vooral op commercieel vlak moet er nog heel wat gebeuren voordat daadwerkelijk sprake is van een markt voor mestproducten. Het is daarbij noodzakelijk dat de gehele mestketen denkt vanuit de door de afnemers gewenste kwaliteit. Om die markt significant te ontwikkelen is gezamenlijke actie nodig. Als partijen samenwerken kan veel efficiënter worden omgegaan met tijd, geld en energie en kunnen onderwerpen worden aangepakt waar individuele bedrijven überhaupt niet in investeren. Die samenwerking kan verschillende vormen aannemen en tot verschillende zaken leiden. Een aantal voorbeelden:

- Delen van techniek en kennis om daarmee technologieontwikkeling te versnellen.

- Afstemming van activiteiten, zodat specialisatie kan ontstaan in producten, technologieën, afzetregio's, etc.

- Het opzetten van een gezamenlijke infrastructuur en distributie.

- Als specifiek onderdeel daarvan kan in gezamenlijkheid gewerkt worden aan certificering.

- Allerhande knelpunten en problemen gezamenlijk oplossen, zodat niet iedere partij zelf het wiel hoeft uit te vinden.

- Gezamenlijk optrekken richting overheid en andere kaderstellende partijen, zodat effectiever beleid kan worden gemaakt.

Hoewel betrokken partijen inzien dat een dergelijke samenwerking veel kan opleveren voor het collectief en dus voor de verschillende leden van het collectief, gebeurt op het gebied van bovengenoemde samenwerking heel weinig. Iedere partij roept wel dat regie nodig is, maar wacht af tot iemand dat op zich neemt.

\section{Mestkwaliteit en organische stof}

- De aanwezigheid van antibiotica, zware metalen, gewasbeschermingsmiddelen en overige micro verontreinigingen is een punt van aandacht.

- Certificering op grond van strak omschreven kwaliteitseisen is nodig.

- $\mathrm{Er}$ is een scala aan technieken nodig om te zorgen voor goede kwaliteit en alle gevraagde producten. Dat betekent dat behoefte is aan samenwerking van gespecialiseerde bedrijven (bedrijfsonderdelen) gericht op specifieke aspecten van het proces van mestverwerking in een cluster dat grootschalige verwerking mogelijk maakt.

\section{Organisatie en logistiek}

- Als mestverwerking grootschalig wordt opgepakt, kunnen er aanpassingen komen in de harde infrastructuur. Er zijn fabrieken nodig, maar ook de opslag op veehouderijbedrijven kan veranderen. Het is niet perse noodzakelijk om zelf voor een aantal maanden opslag te hebben. Zeker als mestverwerking wordt gecombineerd met vergisting kan een snelle verwerking in een fabriek belangrijk zijn. Als veehouderijbedrijven in een cluster liggen, moeten andere transportsystemen dan per vrachtauto over de weg overwogen worden. 
- Verandering in transportbehoefte (binnen Nederland en naar het buitenland) moet onderzocht worden

- De partijen in de keten zullen andere rollen op zich nemen, te denken valt onder meer aan mengvoerleveranciers en kunstmestproducenten en -leveranciers die (helpen) sturen op mestkwaliteit op het veehouderijbedrijf en de verdere verwerking.

- Centrale regie is belangrijk: de partijen zullen moeten samenwerken en een vorm van regie moeten opzetten. Alle stakeholders in de keten zijn daarbij nodig, zowel overheid, primaire landbouwbedrijven als ketenpartijen.

- Er zullen institutionele belemmeringen zijn, zoals locaties en vergunningen, maar ook nieuwe vormen van samenwerking moeten worden ontwikkeld. De volksgezondheid is een punt van aandacht.

Kosten

- $\quad$ Het is de vraag op welke basis mestverwerking moet worden georganiseerd. Bij humane mest is dat collectief en worden aan de burger verwerkingslasten opgelegd. Bij dierlijke mest is dat momenteel privaat, waarbij iedere veehouder eigen afzetkanalen zoekt. In sommige gevallen is sprake van een coöperatie die mestverwerking organiseert (bv de pluimveesector met BMC). Een optie kan zijn mestverwerking te organiseren via een "verwijderingsbijdrage" bijvoorbeeld via een toeslag op veevoeders. Nadere discussie over een financieringsmodel is zeker noodzakelijk.

- De kosten voor mestverwerking op de lange termijn zijn direct afhankelijk van de focus in de mestverwerking. Als mest weer een echt product wordt ipv de huidige situatie waarin de kosten bij de veehouder liggen, is de verwachting dat de kosten op lange termijn lager zijn.

- De effecten van de werkwijze bij mestverwerking op kostprijzen van akkerbouw- en veehouderijproducten moeten verder worden onderzocht.

\section{Regelgeving}

- $\quad$ EU kaders zijn leidend voor de grondwaterkwaliteit en daarmee voor de bemesting met zowel dierlijke als kunstmest

- $\quad$ EU kaders zijn leidend bij de financiering van mestverwerking. Dat mag niet leiden tot staatsteun of anderszins "oneerlijke" marktbeïnvloeding binnen de EU.

- Locaties en vergunningen voor mestopslag en -verwerking zijn een bron van lokale spanningen. Nadere overweging van de rollen en bevoegdheden van de verschillende partijen hierin (gemeente, provincie, rijk, waterschap) is waarschijnlijk noodzakelijk om tot een werkbare procedure voor vergunningen voor het bouwen van mestverwerkingsinstallaties te komen

\section{Risico's}

- Veiligheid en gezondheid. Volgens het RIVM-rapport Veehouderij en Volksgezondheid (http://www.rivm.nl/Onderwerpen/V/Veehouderij_en_gezondheid/Onderzoek_veehouderij_en _gezondheid_omwonenden_VGO) is de blootstelling aan contaminanten via de lucht de belangrijkste bron van risico's voor de volksgezondheid van veehouderij. Over de risico's van mestverwerking voor veiligheid en gezondheid verschijnt een kennisbericht van het Kennisplatform Veehouderij en Humane Gezondheid (http://www.kennisplatformveehouderij.nl/).

- Risico's kunnen worden geminimaliseerd door technische voorzieningen bij ontwerp en bouw en door beheersmaatregelen in de bedrijfsvoering. Daar moet bij vergunningsverlening voor mestverwerking op worden gestuurd, maar de wettelijke basis daarvoor is nog niet ontwikkeld. Het rapport Handreiking Veehouderij en Volksgezondheid (Giepmans et al, 2017, van BPO Speerpunt Transitie Duurzame Veehouderij) doet aanbevelingen voor instrumenten.

\subsubsection{Plantaardige productie}

Door het beschikbaar komen van andere vormen van meststoffen, met name in vloeibare vorm, zullen bemestingstechnieken veranderen. Het kan een verdere stimulans zijn tot precisiebemesting en het is mogelijk beter geschikt voor toepassing in fertigatie, de combinatie van bemesting en irrigatie, die bij klimaatverandering aantrekkelijk kan zijn. 
Er zijn meer mogelijkheden om organische stof uit mest binnen Nederland te benutten. Dat geldt voor organische stof uit mest, maar de kans is groot, dat organische stof uit andere biomassa 'meelift'. Dat kan leiden tot hogere gehalten aan organische stof in de bodem, wat ten goede komt aan bodemweerbaarheid en bodemleven. In een of meer Duitse deelstaten is het inmiddels verplicht een bepaalde dosis organische stof toe te dienen. De effecten van een hoger gehalte aan organische stof op o.a. emissies kunnen zowel positief als negatief zijn. Het gaat om een optimaal gehalte dat sterk afhankelijk is van grondsoort, klimaat en landgebruik. Te weinig geeft problemen met onder meer bodemstructuur en beschikbaarheid van nutriënten. Maar te veel is ook niet goed, dat veroorzaakt soms extra uitspoeling van $\mathrm{N}$ en daarmee problemen met Kaderrichtlijn Water. De interactie tussen alle bodemfuncties is dusdanig complex dat er wetenschappelijk nog veel vragen zijn over de hoeveelheid organische stof en bodemleven, nodig voor een optimale nutriëntenbenutting. Bodemkwaliteit is niet eenduidig en algemeen geldend te omschrijven. Dat komt vooral omdat een bodemeigenschap voor de ene ecosysteemdienst waardevol is en voor een andere negatief kan werken. Bodemkwaliteit moet dus altijd specifiek worden omschreven in relatie tot de gevraagde diensten, klimaat en landgebruik.

Regels voor stimuleren van optimale organische stofgehalten van de bodem zijn wenselijk voor bodemkwaliteit op de lange termijn. Dergelijke regels helpen ook bij de gerichte en juiste afzet van mestproducten. In de bijlagen 9 (werking kunstmestvervangers) en 10 (effecten mestbeleid) wordt nader ingegaan op effecten van mestverwerking op de bemestende waarde.

\subsubsection{Dierlijke productie}

Veehouders moeten zich bewust worden dat mest een grondstof is voor een volgende fase. Dat betekent ook dat mestverwerking al aan de voorkant begint:

- $\quad$ de veevoeding heeft invloed op de kwaliteit van de mest, zowel in nutriëntengehalten als winbaarheid ervan. Het huidige sturen op een zo laag mogelijke excretie is niet een absolute voorwaarde meer en kan mogelijk worden vervangen door sturing op winbaarheid van uitgescheiden nutriënten en op de onderlinge verhoudingen van $\mathrm{N}$, P en $\mathrm{K}$ en op de andere inhoudsstoffen, zoals zware metalen en andere toevoegmiddelen.

- $\quad$ gescheiden opvang van mest en urine. Bij mestverwerking speelt scheiding een belangrijke rol. Door aanpassingen in de huisvesting kunnen mest en urine gescheiden worden opgevangen. Dat maakt de latere verwerking eenvoudiger. Bovendien heeft het meer voordelen: de noodzaak tot luchtwassers wordt kleiner, het stalklimaat zal verbeteren en er blijft meer $\mathrm{N}$ in de mestproducten. In mengmest verdwijnt een aanzienlijk deel als $\mathrm{NH3}$. Aanpassingen in stallen kunnen niet van vandaag op morgen worden gerealiseerd, stallen worden voor een periode van 20 - 25 jaar gebouwd. Daarnaast passen nieuwe concepten vaak niet in de bestaande regels voor vergunningen. Er zijn ontheffingen nodig, het vergt tijd, er dient risicodragend geïnvesteerd te worden. Overheden moeten ruimte (durven) geven. Verschillende overheden moeten samenwerken en continuïteit van ambtelijke begeleiding is belangrijk.

De bovengenoemde aanpassingen in de veehouderij betreffen de wijze waarop dieren worden gevoerd en worden gehouden. Het gaat niet over het volume van de veehouderij in Nederland. Dat wordt mede bepaald door andere factoren. Als door mestverwerking alle overschotten duurzaam worden verwerkt, geëxporteerd en elders goed worden ingezet in de voedselketen, kan de onderbouwing voor sturing van de omvang van de veehouderij via excretie van N en P mogelijk minder sterk worden. Dat kan mogelijk aanleiding zijn tot andere criteria voor het vaststellen c.q. begrenzen van dieraantallen.

\subsubsection{Betekenis voor circulariteit, beleid en rollen en handelingsperspectief}

\section{Circulariteit, de stip op de horizon}

Voor circulariteit moet alle dierlijke (en humane) mest worden hergebruikt binnen of buiten de landbouw. Dat betekent dat er vraag moet zijn naar mestproducten, nutriënten uit mest, organische stof, binnen en buiten landbouw, binnen en buiten Nederland. Door de ruime beschikbaarheid van nutriënten uit kunstmest is er (nog) geen schaarste. Deze schaarste zal kunstmatig gecreëerd moeten worden of de mestproducten moeten kunnen concurreren met de kunstmest. Tegelijkertijd hoeft niet alle mest te worden verwerkt, als mest zonder verwerking nuttig aangewend kan worden, heeft dat de 
voorkeur. De veehouderij zal zich veel sterker dan nu moeten richten op twee hoofdproducten: enerzijds melk/vlees/eieren, zoals nu en anderzijds op een verwerkbare mest. Optimalisatie zal naar beide eindproducten moeten plaatsvinden en niet, zoals nu, op slechts één aspect.

\section{Beleid en rollen}

De samenwerking en afstemming tussen omgevingsdiensten, gemeentes, provincies, waterschappen en de nationale overheid op het vlak van dierlijke mest en nutriëntenmanagement is essentieel. Het beeld is dat het nu qua doelen en beleid nog te versnipperd is.

Tegelijkertijd ontstaan op lokaal niveau dilemma's, met name het verlenen van vergunningen is een knelpunt voor mestverwerking. Het gaat dan om een lokale afweging tussen diverse belangen en om een afweging tussen het gemeenschappelijke/nationale belang en het lokale belang. Hoe kan de overheid (op diverse niveaus) daar de goede dingen doen? Hoe kom je tot een geobjectiveerd beoordelingskader? In dat beoordelingskader spelen naast de technische aspecten ook de gezondheidsrisico's een belangrijke rol. In oktober 2017 heeft het Kennisplatform Veehouderij en Humane Gezondheid een bijeenkomst georganiseerd over de risico's van mesterwerking en een kennisbericht in voorbereiding. In 2016 hebben de Omgevingsdiensten en de GGD in Noord-Brabant, samen met de Provincie (Giepmans et al., 2017) een overzicht uitgebracht met een handreiking voor de positie van humane gezondheid in het vergunningentraject m.b.t. dierlijke productie en mestverwerking.

Veranderingen in veehouderijsystemen vereisen innovatie en ruimte voor nieuwe ontwikkelingen bij de toelating van nieuwe systemen. Recentelijk zijn de regels voor het toelaten van nieuwe elementen in stalsystemen gewijzigd .

Als er veranderingen in veehouderijsystemen komen is ruimte nodig in het vergunningensysteem. De Technische Advies Commissie-Regeling Ammoniak en Veehouderij (TAC-RAV) regelt nauwgezet welke stalsystemen zijn toegestaan en voor aangepaste stalsystemen moet de proefstalstatus verleend worden. Momenteel betekent de werkwijze van de TAC-RAV eigenlijk een rem op innovatie in stalsystemen.

Waar afstemming en samenwerking wat betreft regelgeving vooral een overheidstaak is, ligt dat met de regie op het geheel anders: dat is een gedeelde verantwoordelijkheid van alle stakeholders. Het lijkt er op, dat een katalysator c.q. initiator nodig is, om het geheel van mestverwerking en met name de marktontwikkeling van de grond te krijgen.

\section{Handelingsperspectief van betrokkenen}

De vraag van het handelingsperspectief richt zich op twee thema's: marktontwikkeling en wie de regie op zich neemt. Beiden moeten tegelijkertijd worden opgepakt. De technologie wordt niet als belangrijkste beperkende factor gezien. Zowel bedrijfsleven als overheid moeten in beweging komen en samenwerken.

\footnotetext{
${ }^{1}$ https://www.rijksoverheid.nl/documenten/kamerstukken/2017/06/21/aanpassingen-stalbeoordeling-tacrav
} 


\section{De roep om regie en aanbod-gestuurde actie}

In de workshops is de behoefte aan regie duidelijk naar voren gekomen.

Dit laat zich heel mooi illustreren met het Prisoner's Dilemma: mestverwerkers A en B hebben de keuze tussen wel of niet samenwerken met elkaar. Het levert hen samen het meest op wanneer zij gaan samenwerken; voor beiden heeft dat een duidelijk voordeel ten opzichte van de situatie waarin zij op eigen houtje doorontwikkelen. Maar voor de individuele bedrijven is het nog voordeliger om te profiteren van kennis en inspanningen van de andere partij, zonder daar zelf een open houding tegenover te stellen. Wanneer partij A zich coöperatief opstelt naar partij B, maar partij $B$ doet dat niet terug, dan profiteert $B$ van de inspanningen en kennis van $A$, maar $B$ houdt zijn eigen inspanningen en kennis voor zichzelf.

Bij mestverwerking kunnen partijen wel contact hebben, maar als zij niet alle informatie willen delen of een geheime agenda hebben, blijft het dilemma duidelijk aanwezig. Daarnaast zijn er bij mestverwerking niet slechts twee spelers, maar veel meer. Dat verandert niets aan het principe, maar maakt het nog ingewikkelder. Partijen moeten daarom nadenken over op welke thema's ze wel en niet willen samenwerken, op welke basis ze willen samenwerken en in welke mate ze willen samenwerken.

De overheid kan in een Prisoner's Dilemma een belangrijke rol vervullen als facilitator of scheidsrechter. Maar in het geval van mestverwerking is de overheid zelf ook een speler. Dat wordt duidelijk wanneer de overheid zelf een te grote rol pakt en bijvoorbeeld aan marktontwikkeling gaat doen, of direct investeert in infrastructuur. Uiteraard kan dat het geheel verder helpen, maar tegelijkertijd neemt het de prikkel weg bij andere partijen die deze rol effectiever hadden kunnen oppakken.

Een verdere beschrijving en uitwerking van het Prisoner's Dilemma staat in bijlage 6.2. In de workshops werd vooral een behoefte aan regie geuit, een vraag wie het voortouw gaat nemen. De toonzetting was daarmee anders van aard dan in de casus "geen kunstmest". Daar werden duidelijke rollen gezien en werd actiever geformuleerd wat zou moeten gebeuren om kunstmestvervangers te produceren. In die casus werd niet gevraagd naar regie, daar namen de partijen die (impliciet) op zich.

Het benadrukt nogmaals het belang van de vraag naar producten. Dat kan ook worden geïllustreerd aan de hand van de elektriciteitscentrale die gebruik maakt van pluimveemest, de BMC. In 1987 vinden de eerste gesprekken plaats tussen pluimveehouders en energieproducenten. De pluimveehouders hebben behoefte aan een bestemming voor de mest die zij produceren en de energiesector is op zoek naar nieuwe manieren om energie op te wekken en CO2 te besparen. In 2006 verenigen ruim 600 pluimveehouders zich in de Coöperatie DEP. Zij spreken af 10 jaar lang de levering van pluimveemest te garanderen, waardoor met de bouw van de centrale kan worden begonnen. In 2008 wordt BMC Moerdijk officieel geopend: de elektriciteitscentrale is het resultaat van samenwerking tussen energieproducent PZEM Energy, de land- en tuinbouwsector (ZLTO) en de pluimveehouders, verenigd in Coöperatie DEP (http://www.bmcmoerdijk.nl/). Indertijd was ook ThermPhos erbij betrokken om de fosfaat uit de as te gebruiken. Dat onderdeel is mislukt. Maar het illustreert wel het belang van de vraag in de markt. Als die er is, organiseren mensen zich wel. 


\section{Conclusies}

\section{$4.1 \quad$ Geen kunstmest}

De maatregel "geen kunstmest" zal in enige mate bijdragen tot een beter sluiten van nutriëntenkringlopen. Dat effect is sterker bij stikstof dan bij fosfaat of kali. Het blijkt ruimschoots mogelijk om de bemesting met $\mathrm{P}$ en $\mathrm{K}$ te dekken uit dierlijke mest, voor $\mathrm{N}$ moet ook raffinage van $\mathrm{N}$ uit menselijke excrementen worden toegepast, met als aanvulling nog de grootschalige inzet van klaver in grasland en het gebruik van spuiwater en slachtafval. Met name de schaarste aan $\mathrm{N}$ zet aan tot een potentieel betere benutting van de aanwezige $\mathrm{N}$ in organische producten.

Om de bemesting van N, P en $\mathrm{K}$ te kunnen sturen, is een goede scheiding nodig van de drie nutriënten uit de dierlijke mest. De maatregel is een sterke stimulans voor mestverwerking.

De $\mathrm{N}$ emissies naar lucht en water zijn afhankelijk van de werking van de $\mathrm{N}$ concentraten ten opzichte van kunstmest $\mathrm{N}$.

De kostprijs van producten zal in de akkerbouw stijgen en in de intensieve veehouderij afnemen. Melkveehouderij neemt een tussenpositie in, afhankelijk van de mate waarin ze mest moeten afvoeren.

\subsection{Mestverwerking}

Het is niet bekend of de maatregel "mestverwerking" bijdraagt aan het beter sluiten van nutriëntenkringlopen. De reden daarvoor is dat de bestemming van de verwerkte producten niet bekend is in deze aanbod gestuurde maatregel. Het belangrijkste inhoudelijke resultaat van de verkenning is het constateren van grote belang van het ontwikkelen van een (internationale) markt voor mestproducten, de noodzaak tot samenwerking tussen partijen en de belemmeringen voor die samenwerking. Een ander inzicht was het verschil in kostenstructuur tussen de verwerking van menselijke uitwerpselen (publiek geregeld) en dierlijke uitwerpselen (volledig privaat). Een tussenvorm zou een verwijderingsbijdrage via bijvoorbeeld veevoer kunnen zijn, waarmee een investeringsfonds gevormd zou kunnen worden².

\footnotetext{
2 Momenteel is er een Mestinvesteringsfonds, dat via achtergestelde leningen investeringen in mestverwerking faciliteert (http://www.mestverwerkingsloket.nl/mestinvesteringfonds/), maar niet zelf financiert en zijn er subsidiemogelijkheden voor mestverwerking uit Europese steunregelingen (http://www.mestverwerkingsloket.nl/regeling-stimulering-mestverwerking/). Beide regelingen trachten nog initiatieven van de grond te krijgen.
} 


\section{Uitvoering van de KringloopToets}

Voor gedeeld inzicht in de effecten van een maatregel, moet die maatregel een duidelijk afgebakende nieuwe situatie zijn, die met de huidige situatie vergeleken kan worden. Omdat mineralen in de KringloopToets centraal staan moet de bestemming van de mineralen in de nieuwe situatie helder zijn. Achteraf gezien bood de maatregel "alle varkensmest verplicht verwerken" te veel verschillende uitwerkingsmogelijkheden en daardoor geen overzichtelijke nieuwe situatie. De maatregel "geen kunstmest meer", dwingt tot het beter benutten van mineralen uit dierlijke mest, maar "mest wordt verplicht verwerkt" zonder dat helder is wat de producten zijn en waar en hoe die afgezet gaan worden blijkt dat niet te doen. Een maatregel moet zorgen voor trekkracht in de nutriëntenketen. Dan is het voor alle partijen helder waar het naar toe gaat. Een maatregel die aanbodgericht is (zoals alle varkensmest wordt verwerkt), levert te veel verschillende toekomstbeelden op. Dan wordt het lastig onderliggende waarden bij de deelnemers expliciet te maken. De KringloopToets in de huidige vorm kan dat niet goed hanteren.

Voor breed gedragen en gedeelde inzichten is continue betrokkenheid van essentiële stakeholders noodzakelijk, ook als een stakeholder zelf terughoudend is om deel te nemen. De juiste deelnemers aan tafel krijgen vereist nog meer inzet van de uitvoerders. Als de KringloopToets bekender wordt en resultaten bruikbaar blijken, zal dat eenvoudiger worden.

Voor uitvoering van een KringloopToets wordt met de opdrachtgever overlegd over de scope en de te betrekken stakeholders. De uitvoering van de KringloopToets Mestverwerking heeft ons geleerd, dat de keuze van de maatregel invloed heeft op het verloop en de resultaten van de toets. In het draaiboek, dat voor de KringloopToets in ontwikkeling is, nemen we op, dat ook de te bespreken maatregelen in het vooroverleg met de opdrachtgever meegenomen moeten worden. 


\section{Bijlagen mbt deelnemers en inhoudelijke informatie}

De bijlagen 5.1 en 5.2 geven een overzicht van deelnemers aan de workshops en experts die inhoudelijke bijdragen hebben geleverd. In bijlage 5.3 is informatie die ingebracht werd na afloop van de workshops samengevat. De bijlagen 5.4 tot en met 5.12 geven inhoudelijke informatie.

\subsection{Deelnemers workshop}

De opmerkingen van de deelnemers op de rapportage zijn verwerkt. Echter, niet alle conclusies en aanbevelingen worden door alle deelnemers in dezelfde mate volledig onderschreven.

\begin{tabular}{ll} 
Organisatie & Naam \\
Ministerie Infrastructuur en Milieu & Jan van Bergen \\
\hline Ministerie Economische Zaken & Harm Smit \\
\hline Vereniging Diervoederonderzoek Nederland & Harmen van Laar \\
\hline Vereniging Diervoederonderzoek Nederland & Johan Temmink \\
\hline Vereniging Diervoederonderzoek Nederland & Jan Schellekens \\
\hline Land en Tuinbouw Organisatie & Frits Mandersloot \\
\hline Waterschap Rijn en IJssel & Ellen Besseling \\
\hline Yara & Koen van Keer \\
\hline Brabantse Milieu federatie & Piet Rombouts \\
\hline Van Iperen & Piet Riemersma \\
\hline Nevedi & Marc Heijmans \\
\hline
\end{tabular}

Uitgenodigde organisaties voor de workshops KringloopToets mestverwerking:

\begin{tabular}{l} 
Organisatie \\
Ministerie I\&M \\
\hline Ministerie EZ \\
\hline Provincie Noord-Brabant \\
\hline LTO melkveehouderij \\
\hline LTO akkerbouw \\
\hline Kunstmestindustrie via VCNI \\
\hline Waterschap Rijn en IJssel \\
\hline RABO bank \\
\hline Vereniging Diervoederonderzoek Nederland \\
\hline Brabantse Milieu federatie \\
\hline Stichting Natuur en Milieu, (persoonlijk) \\
\hline
\end{tabular}

Overige deelnemers aan de workshops KringloopToets mestverwerking:

\begin{tabular}{ll} 
Organisatie & Naam \\
Wageningen universiteit en research & Trond Selnes \\
\hline Wageningen universiteit en research & Nico Verdoes \\
\hline Wageningen universiteit en research & Ferry Leenstra \\
\hline Wageningen universiteit en research & Theun Vellinga \\
\hline innovatiesocioloog & Bart Bremmer \\
\hline WING & Joost Tersteeg \\
\hline
\end{tabular}




\subsection{Experts die een bijdrage hebben geleverd}

\begin{tabular}{ll} 
Organisatie & Naam \\
\hline Wageningen universiteit en research & Gerard Velthof \\
\hline Wageningen universiteit en research & Willy Baltussen \\
\hline Wageningen universiteit en research & Marieke Meeusen \\
\hline Wageningen universiteit en research & Jantine van Middelkoop \\
\hline Bouis Bolk Instituut & Jan de Wit \\
\hline Blonk Consultants & Jasper de Groot \\
\hline DLV Agri\&Food & Hans Blonk \\
\hline
\end{tabular}

\subsection{Additionele informatie}

Bij het becommentariëren van de concept-rapportage maakten een aantal deelnemers aanvullende opmerkingen en vragen. Deze opmerkingen en vragen zijn hieronder geanonimiseerd weergegeven. Deze na afloop van de workshops binnengekomen vragen zijn niet verder uitgewerkt cq beantwoord.

\section{Aanvullingen en opmerkingen 1}

Samen met de sectororganisaties hebben EZ en IenM gemeend dat het goed zou zijn om de onafhankelijk kennis op het gebied van mestverwerking te vergroten. In opdracht van EZ is daarom in het voorjaar van 2017 gestart met een verkenning voor de oprichting van een Nederlands Coördinatiecentrum Mestverwerking (NCM). Een dergelijk centrum is in Vlaanderen redelijk succesvol. Het centrum kan bijdrage aan de kennisontwikkeling en -verspreiding over mestverwerking voor bedrijven en overheden. Het is de verwachting dat eind 2017 een beslissing wordt genomen over de oprichting van het NCM.

\section{Aanvullingen en opmerkingen 2}

Bij kunstmest weten we exact, tot op de $\mathrm{kg} / \mathrm{ha}$ wat bij iedere kunstmestgift aan $\mathrm{N}, \mathrm{P}$ en $\mathrm{K}$ geven wordt gegeven. Dat is voor organische stromen ondoenlijk.

Nog serieuzer is dat de manier van toediening van dierlijke mest met een flinke milieubelasting gepaard gaat.

De $\mathrm{N}$ uit de organische stromen komt in het voorjaar - voor de 1e snede - te laat vrij. Hoe moet dat zonder kunstmest-N worden gecompenseerd?

De $\mathrm{N}$ uit de organische stromen komt in het najaar - na de laatste snede (?) - nog volop vrij door voortgaande bodemprocessen. Dit noemen wij uitspoeling van nitraat. In strijd met de richtlijnen? Hoe zit het met precisiebemesting. Dit verdraagt zich niet of uiterst moeizaam met recirculatiestromen, omdat alle elementen/mineralen 'aan elkaar vastzitten'. Dus apart $\mathrm{N}$, apart $\mathrm{K}$ en apart $\mathrm{P}$ dosering is niet mogelijk? Hetzelfde geldt voor variabel per element bemesten op basis van taakkaarten?

Hoe krijgen/houden we balans met de spoorelementen als N,P en K leidend zijn.

Hoe zit het met de energie-efficiëntie en carbonfootprint van organische en gerecycleerde meststoffen? Er wordt vaak "aangenomen" dat de LCA performance van organische/gerecycleerde meststoffen beter is dan die van conventionele minerale meststoffen. Maar is dat effectief wel zo? Is er daar voldoende en degelijke wetenschappelijke informatie over?

\section{Aanvullingen en opmerkingen 3}

Bij de casus 'stoppen met kunstmest': $100 \%$ is nooit haalbaar omdat er altijd verlies van nutriënten optreedt, dat aangevuld moet worden om een gelijke gewasopbrengst te behouden. In de eerste fase is door betere bemesting e.d. wel een inhaalslag te behalen, maar gelet op de grilligheid van de 
natuur (teveel neerslag), kan een optimale bemesting deels weer teniet worden gedaan. Opgelet moet worden dat we hierin niet doorschieten.

Bij scenario's, waaronder 'staarten tellen': Het verminderen van het aantal dieren in Nederland hoeft niet te leiden tot een betere evenwichtsbemesting. Het gebruik van onbewerkte drijfmest heeft in zich dat vooral in het voorjaar de drijfmest en dus de mineralen op het land worden gebracht met een bepaalde werkingscoëfficiënt die zonder be- of verwerking van de mest niet is te verbeteren. Voor een optimale kringloop met zo gering mogelijke verliezen is een vorm van mest be- en/of verwerking juist nodig. Financieel kan het dan wel aantrekkelijk zijn om juist mestoverschot te hebben met wel de vraag hoe groot deze kan/mag zijn voor een optimale mestverwerking.

Bij vraag naar dierlijke mest vanuit de akkerbouw: vragers naar mest vragen goed inzetbare meststoffen die deels van organische oorsprong zijn omdat deze essentieel zijn voor de gewasteelt. Ze vragen in principe niet om onbehandelde mest, maar dit is een gevolg van de markt/prijs/aanbod Bij akkerbouw krijgt betaald voor dierlijke mest en heeft dus nu geen probleem: Wel als ook akkerbouwers 'afgerekend' worden op het sluiten van de kringloop met zo weinig mogelijk mineralenverliezen. Dit is dan weer het sturingsinstrument om al of niet het gebruik van drijfmest nog mogelijk te maken. Dit is een beleidsmatige keuze.

Bij de biologische sector is meer afhankelijk van dierlijke mest: De vraag is wel hoe efficiënt hierin de kringloop is. Een varken dat buiten loopt en zijn mest met meerdere dieren op één plaats deponeert, geeft ook piekbelastingen en maakt het efficiënt in kunnen zetten van deze mineralen niet mogelijk. Het wordt echter vanuit beleid geaccepteerd, maar de vraag is of dit vanuit milieuoogpunt gewenst is. Denk ook aan de grotere ammoniakemissies per gemiddeld aanwezig dier e.d. Ook hier kan anders naar gekeken worden vanuit de gedachte van mineralenkringloop.

Bij de casus verwerken varkensmest verplicht: Zou feitelijk voor elk bedrijf dat mest produceert kunnen gelden en dus ook voor bedrijven in andere EU-landen.

Bij tekort aan $N$ aanvullen vanuit andere bronnen: bij 50\% benutten NH3 uit stallucht van varkens zou ca. 15 kton $\mathrm{N}$ zijn te winnen

Bij Tabel 1 In tabel 1 is nog niet mee genomen welke eventuele betere mineralenbenutting mogelijk is bij gebruik van bewerkte mest. $\mathrm{Nu}$ is uitgegaan van een bepaald mineralenverlies wat wellicht minder kan worden in de toekomst en waardoor minder aanvoer nodig is. Om hoeveel kg NPK gaat het dan nog? Echter akkerbouwers op kleigrond geven nu wel al aan dat de fosfaatgift zo laag is dat door gedeeltelijke fixatie van de fosfaat de gewasopbrengst onder druk staat, terwijl de lage normen ingegeven zijn door de overbemesting in het verleden op de meer zuidelijke zandgronden. Ook hier moet oog voor zijn om niet door te schieten.

Bij verwachte toename van transport van onverwerkt mest: transport, uitgedrukt in transportkilometers, zal juist afnemen omdat minder water in de mest over grote afstanden vervoerd zal worden. De verwerking vindt plaats op korte afstanden in de productieregio's van de mest.

Bij stimulans over te schakelen op biologisch: Dit lijkt me onwaarschijnlijk omdat de uitbreiding van biologische landbouw vooral vraag gestuurd is en niet vanuit de productievoorwaarden. Biologische landbouw zal een beperkte omvang blijven behouden omdat de producten simpelweg te duur zijn voor de gemiddelde consument of die heeft er het geld niet voor over. Er moet gewaakt worden voor overschatting waardoor verkeerd beleid wordt gemaakt.

Bij in Nederland is men bereid veel voor grond te betalen: Hier mee opletten omdat de ondernemers met de beste financiële resultaten de prijs bepalen en anderen hierdoor gedwongen worden deze vaak te hoge prijs te betalen. Voor het gemiddelde klopt dit niet en daalt het bedrijfsinkomen wel degelijk, zie ook het recente rapport dat is gemaakt voor de provincie Noord-Brabant naar de gevolgen van versnelde invoering van het emissiearm moeten maken van de stallen. 
Bij verwachte dalende mestafzetkosten voor intensieve veehouderij bij geen kunstmest: Dit is niet juist als er meerkosten komen om de mest te bewerken voor een betere benutting. Een opbrengstprijs voor dierlijke mestproducten wil nog niet zeggen dat de totale mestkosten dalen. $\mathrm{P}$ en $\mathrm{K}$ is er nog over, dus zal toch geëxporteerd moeten worden.

Bij tekstblok: verplaatsen van het probleem: Dit is wel mogelijk als de mestproducten uiteindelijk in korrelvorm worden geproduceerd en in deze vorm terug gaan naar deze regio's waar nu de producten vandaan komen. Het is het beleid in deze landen die het mogelijk maken dat de kringloop mede niet gesloten kan worden. Echter deze landen willen juist op deze wijze een stijging van de welvaart ook als dit op korte termijn uitholling van de bodem is (denk aan plat branden van bossen). Op dat gebied is het ook nodig wereldwijd te denken. De algemene vraag is wel of we producten wel van alle plaatsen van de wereld moeten willen halen, maar dit blijft prijs gedreven en dus gebeuren. Ook hierin moeten we als Nederland niet doorschieten, tenzij we bewust aansturen op een kleinere Nederlandse landbouw met een kleine handelsoverschot. Daarbij is de vraag tot hoe ver het beleid bereid is dit te laten komen. Het is dus ook vooral een economische afweging die gemaakt zal worden.

Bij tekstblok vraaggestuurd of aanbodgestuurd: Deze (markt voor dierlijke mest) is er deels al, maar kan alleen ontstaan als er ook aanbod is van een goede kwaliteit en omvang. Daarbij de prijs/kwaliteit erg bepalend. Het opbouwen van een markt kost veel tijd omdat nieuwe gebruikers eerst zelf de positieve ervaringen met mestproducten moeten ervaren alvorens er voor te willen en kunnen betalen. Daarbij speelt ook een grote rol of de gebruikers voldoende financiële middelen hebben om producten af te nemen die geld kosten. Het blijft dus een wisselwerking, die best wat gedrukt mag worden vanuit Nederland, maar dan wel zodanig dat een veehouder in Nederland er van op aan kan dat het beleid ook consistent is, wat vaak niet het geval is. Voorlopers worden nog te vaak gedupeerd in deze, is de praktijkervaring.

Bij regelgeving: Vooral in Noord-Brabant is de vraag of de overheid wel bereid is mest- verwerking mogelijk te maken. Er moet wel een wil zijn om te komen tot mestverwerking op de meest geschikte locaties. Het "not in my backyeard" effect is groot.

Bij gescheiden opvangen van mest en urine: Simpel gesteld wel, maar is praktisch en financieel lastig. Tevens wordt dit door versnelde invoering van andere beleidszaken, zeker in Noord-Brabant, gedwarsboomd. Hier geldt ook dat beleid/regelgeving sterk sturend is.

Bij beleid en rollen: Niet alleen belang maar ook wettelijke verplichting tot mest verwerken. Als iets wordt verplicht moet er wel ruimte worden geboden om hieraan te voldoen, anders ontstaat er een niet handhaafbare situatie.

Bij vergunning voor veranderen van stallen: Niet geheel juist omdat proefstallen juist mogelijkheden bieden. De omschakeling naar een Pool moet wel leiden tot een snellere toekenning van proefstallen en/of opname in de regelingen.

Bij handelingsperspectief van betrokkenen: is echter technisch nog wel problematisch als het gaat om zowel $\mathrm{N}, \mathrm{P}$ en $\mathrm{K}$ goed te scheiden van elkaar.

\section{Aanvullingen en opmerkingen 4}

Bij samenvatting: Dierlijke mest kan genoeg $\mathrm{P}$ en $\mathrm{K}$ bevatten, maar geen 1 op 1 en directe relatie met voerimport.

Gebruik van 'fosfaatbommen' via verwerkte varkensmest hoeft zeker niet te leiden tot meer o.s., dit is van vele factoren afhankelijk. 


\subsection{Dierlijke mest in Nederland}

De cursieve delen van de tekst zijn ontleend aan de startnotitie van het Agile Team mest van Wageningen UR, een organisatie-breed team dat werkt aan integrale oplossingen voor de mestproblematiek.

In de 2de helft van de 20e eeuw is de productie van de Nederlandse landbouw sterk toegenomen, door specialisatie, intensivering en opschaling. De totstandkoming van de Europese Economische Gemeenschap (EEC, nu Europese Unie) en het gemeenschappelijk landbouwbeleid hebben daarbij een rol gespeeld. Ook de goede bodemvruchtbaarheid, infrastructuur, logistieke organisatie, kennis en niveau van onderwijs en onderzoek zijn van belang. De import van grondstoffen voor goedkoop veevoer heeft sterk bijgedragen aan de vergroting van de dierlijke productie. In 2013 was de toegevoegde waarde van de primaire productie 10,5 miljard euro, overeenkomend met ca $2 \%$ van de totale economie. De totale bijdrage van het agrocomplex aan de economie was 8\% (LEB, 2015).

Een keerzijde van de sterke groei is de toename van de emissies van stikstof en fosfaat (en andere stoffen zoals koper en zink) uit de landbouw naar het milieu. Ook worden vragen gesteld over de intensieve veehouderij met betrekking tot dierenwelzijn, risico van antibioticaresistentie, zoönose, en de aantasting van het landschap. De emissies leiden tot bodem-water- en luchtverontreiniging en tot risico's voor de gezondheid van mens en dier en tot verlies van milieukwaliteit en biodiversiteit. Vanaf de jaren 1970 groeide het besef dat er grenzen zijn aan de groei van de landbouw.

Mestbeleid werd geïnitieerd in 1984 (mestbeleid, omdat de verontreinigingen destijds vooral aan dierlijke mest werden toegeschreven). Een gefaseerde invoering werd voorzien: (i) (1984-1989) productiebeperkingen in de veehouderij (mestproductiequota in de pluimvee- en varkenshouderij die later werden omgezet in dierrechten), toedieningsnormen voor mest, stimulering mestdistributie; (ii) (1990-1994) aanscherping productiebeperkingen en toedieningsnormen, stimulering mestverwerking, en ammoniakbeleid (emissiearme mestopslag en -toediening); (iii) (1995 - heden) naar evenwichtsbemesting. In deze fase zijn een groot aantal aanpassingen (o.a., gebruiksnormen vanaf 2006) en aanvullende maatregelen geïmplementeerd. Evenwichtsbemesting voor fosfaat is in 20142015 gerealiseerd, op nationaal niveau.

De grootte van het overschot aan mineralen wordt bepaald door de gebruiksruimte voor stikstof en fosfor ( $\mathrm{N}$ en $\mathrm{P}$ ). De normen voor de gebruiksruimte zijn gebaseerd op maximaal toelaatbare emissies naar grond- en oppervlaktewater. Voor beide mineralen zijn gebruiksnormen vastgesteld en kunnen dus overschotten worden gedefinieerd. Voor $\mathrm{N}$ geven de gebruiksnormen informatie over de hoeveelheid uit dierlijke mest en over de totale hoeveelheid $\mathrm{N}$. Bij fosfor wordt geen onderscheid gemaakt naar de oorsprong.

De gebruiksnormen vinden op hun beurt een wettelijke onderbouwing in de Kaderrichtlijn Water (KRW) en in de Nitraatrichtlijn van de Europese Unie. In Nederland wordt de uitwerking beide richtlijnen vorm gegeven via actieprogramma's. Meer informatie over de gebruiksruimte is te vinden op de website van de Rijksdienst voor Ondernemend Nederland, (RVO, http://www.rvo.nl/onderwerpen/agrarisch-ondernemen/mest-en-grond/mest). Uiteindelijk wordt de effectiviteit van het beleid afgemeten aan de concentraties van $\mathrm{N}$ en $\mathrm{P}$ in grond- en oppervlaktewater, voor zover deze aan de landbouw kunnen worden toegeschreven.

Het verschil tussen de geproduceerde hoeveelheden $\mathrm{N}$ en $\mathrm{P}$ en de aangewende hoeveelheden op basis van de gebruiksruimte moet worden verwerkt. De wettelijke definitie van verwerking is a) het verwerken volgens specificaties van een afnemer en b) het exporteren van fosfaat buiten de landsgrenzen.

De nadruk bij mestverwerking ligt sterk op $\mathrm{P}$ (en deels op $\mathrm{N}$ ) en betreft alleen het wegwerken van het overschot. $\mathrm{Er}$ is geen enkele expliciete sturing met betrekking tot de kringloop van nutriënten. Een groot deel van de mest die op dit moment verwerkt wordt, wordt geëxporteerd naar België, Frankrijk en Duitsland. Zodra het over de grens is, is het 'verwerkt'. 
In het verleden is er weinig sturing geweest op mestverwerking en ontstonden allerlei bedrijven en bedrijfjes die zich richtten op het verwerken van mest om de mest of een deel daarvan buiten Nederland te kunnen afzetten. Sinds 2014 is mestverwerking verplicht voor bedrijven met overschot aan dierlijke mest, Een overschot op bedrijfsniveau is de hoeveelheid mest (bepaald via $\mathrm{N}$ en of $\mathrm{P}$ die niet plaatsbaar is op het eigen bedrijf volgens de gebruiksnormen, waarbij de mestverwerkingsplicht alleen geldt voor het overschot op basis van P. In combinatie daarmee is per regio in Nederland bepaald welk percentage van het overschot aan dierlijke mest voor centrale verwerking moet worden aangeboden. In totaal is er nu een mestverwerkingscapaciteit in Nederland van bijna 30 miljoen kg ( $\mathrm{Mkg}$ ) fosfaat. De verplichte mestverwerking is gekoppeld aan de regionale overschotten: in 2017 moet 59, 52 en $10 \%$ van het overschot op bedrijfsniveau worden verwerkt voor respectievelijk de regio's zuid, oost en de rest van Nederland). Er mag tussen regio's en tussen bedrijven worden verhandeld. In totaal wordt $51.9 \mathrm{Mkg}$ fosfaat afgezet buiten de Nederlandse landbouw. Het betekent dus dat bijna 22 miljoen $\mathrm{kg}$ fosfaat buiten de Nederlandse landbouw wordt afgezet zonder enige vorm van verwerking. Volgens de wettelijke definitie is dat echter wel te beschouwen als "verwerkte" mest.

Door het mestbeleid is de milieubelasting drastisch verminderd, maar milieudoelen met betrekking tot de emissie van ammoniak naar de atmosfeer, stikstofdepositie op natuur, nitraat in grondwater, stikstof en fosfaat in oppervlaktewater zijn niet gerealiseerd. De productiekosten voor (intensieve) veehouders zijn toegenomen, vooral door de verplichte mestafzet (waarvan een deel moet worden verwerkt). Door het overschot heeft mest een negatieve economische waarde en de transport- en verwerkingskosten van dunne mest zijn hoog, vooral door het lage droge-stofgehalte. Daardoor is de concurrentiekracht van de veehouderij afgenomen en is het risico van mestfraude toegenomen. Ook is de regelgeving ingewikkeld geworden, vooral voor melkveehouders.

Ruim een kwart van de totale mestproductie (170-180 miljoen $\mathrm{kg}$ fosfaat) moet worden verwerkt en het fosfaat in die mest moet worden geëxporteerd. Het doel van de export is om fosfaatevenwichtsbemesting te kunnen realiseren. Met die export worden ook stikstof, andere nutriënten en organische stof geëxporteerd. In 2015 werd bijna 44 miljoen $\mathrm{kg}$ mestfosfaat geëxporteerd, waarvan een deel in niet of beperkt verwerkte vorm (gehygiëniseerd).

Mestverwerking en de afzet van verwerkte mest in het buitenland is de achilleshiel van het mestbeleid (en de veehouderij), omdat het gezien wordt als dure afvalverwerking en weinig aandacht wordt besteed aan de afzet. Het is dus de vraag in hoeverre mestverwerking bijdraagt aan het beter sluiten van nutriëntenkringlopen. 


\subsection{Elementen uit beleidsnota Circulariteit}

Onderstaande tekststukken zijn integraal overgenomen uit de beleidsnota circulariteit van de ministeries van I\&M en EZ.

\section{STRATEGISCHE DOELEN}

Voor de prioriteit biomassa \& voedsel worden de drie strategische doelen in het programma op de volgende manier vertaald:

1. Optimaal benutten van biomassa en voedsel door het sluiten van kringlopen. Alle grondstoffen en (half-) producten blijven zo lang en zo hoogwaardig mogelijk in de kringloop, door volledige benutting van grondstoffen, hoogwaardig gebruik van biomassa en recycling van reststromen. Daarbij hoort ook het zo efficiënt mogelijk omgaan met biomassa (cascadering en meervoudige verwaarding) door onder meer het tegengaan van (voedsel-) verspilling, het voorkómen van afvalstoffen, het gedoseerd toepassen van meststoffen en efficiënte verbranding;

2. Het reduceren van het gebruik en het vervangen van fossiele grondstoffen door duurzaam geproduceerde biomassa;

3. Ontwikkelen en implementeren van nieuwe manieren van produceren en consumeren die leiden tot verbeteringen en trendbreuken in de omgang met biomassa en voedsel. Een voorbeeld hiervan is de transitie naar gebruik van alternatieve eiwitten.

WAT WE DOEN.

\section{Kringloopsluiting}

Van afval naar grondstof

Het kabinet ondersteunt zoveel mogelijk initiatieven die gericht zijn op het sluiten van kringlopen, het produceren van gerecyclede grondstoffen en op het zo hoog mogelijk en meervoudig verwaarden van biomassa. Voorbeelden zijn de Green Deal 'de Grondstoffenfabriek', waar de Waterschappen actief zijn om uit afvalwater nuttige grondstoffen terug te winnen en de Green Deal 'Business met biomassa en biobased gas'.

\section{Bodemkwaliteit}

Om biomassa voor voedsel en andere toepassingen te kunnen produceren is het behoud van een vruchtbare en gezonde bodem van essentieel belang. Bodemkwaliteit staat met de intensieve landbouw in Nederland onder druk. Om de bodem op de lange termijn gezond en productief te houden, is het van belang dat voldoende stabiele organische stof en optimale hoeveelheden nutriënten in de bodem aanwezig zijn. Het verhogen van stabiele organische stof in de bodem levert ecosysteemdiensten op door vergroting van het waterbergend vermogen, verhoging van de weerstand tegen ziekten en plagen en vastleggen van koolstof in de bodem om klimaatverandering tegen te gaan.

\section{Nutriëntenkringloop}

Naast goed bodembeheer is het nodig te streven naar vergaande sluiting van de nutriëntenkringloop. Het gaat om essentiële nutriënten als fosfaat, stikstof en micronutriënten, die deels potentieel schaars zijn (fosfaat) en waarbij de winning, productie en de toepassing ook aanleiding kunnen zijn voor milieuproblemen (eutrofiëring, broeikasgasemissies en verontreiniging).Er wordt ingezet op zoveel mogelijk terugwinnen van nutriënten uit reststromen om die weer te kunnen hergebruiken. In grote delen van Nederland worden de doelwaarden van de kwaliteit van het grond- en oppervlaktewater echter niet gehaald. Het Nederlandse mestbeleid moedigt agrariërs aan hun gewassen te telen met steeds minder input van stikstof en fosfaat. Dit stimuleert het efficiënt gebruik van nutriënten in de landbouw.

\section{Precisielandbouw}

Een verdere stap in het sluiten van de nutriëntenkringloop is de ontwikkeling van precisielandbouw, waardoor de nutriënten op de juiste plek, in de juiste hoeveelheden en op het juiste moment worden toegepast en minder nutriënten verloren gaan. Daarmee wordt tevens voorkomen dat nutriënten weglekken naar het milieu en daar voor eutrofiëringsproblemen zorgen. Dit wordt gestimuleerd door een uitgebreid innovatieprogramma binnen de topsector Agri\&Food. Een uitdaging is om gerecyclede nutriënten opnieuw te gaan gebruiken, door de toepassing van technieken als precisielandbouw.

\section{WAT GAAN WE DOEN?}

\section{Kringloopsluiting}

\section{Nutriëntenkringloop en bodemkwaliteit}

Samen met de landbouw- en afvalsector wordt onderzocht welke maatregelen mogelijk zijn om meer stabiele organische stof in de bodem te brengen, bijvoorbeeld om organische stof terug te winnen uit 
reststromen, om de bodemkwaliteit te verbeteren en koolstof in de bodem vast te leggen en bodemdaling tegen te gaan. Dit past goed bij het Franse 4 pour 1000 initiatief dat is gericht op het verhogen van het organische stof gehalte in de bodem met 4 promille/jaar voor verbetering van bodemvruchtbaarheid, voedselzekerheid en het halen van de klimaatdoelen van Parijs. Nederland ondersteunt dit initiatief.

Meststoffenverordening

$\mathrm{Er}$ is een grote potentie om nutriënten als fosfaat terug te winnen uit reststromen als mest, afvalwater, zuiveringsslib en uit de industrie en daarmee bij te dragen aan de ontwikkeling van een circulaire economie. Het door de Europese Commissie gepresenteerde voorstel voor herziening van de Meststoffenverordening is een uitbreiding van de harmonisatie van de eisen voor de handel van kunstmest naar die in organische meststoffen, bodemverbeteraars en groeimedia, zoals we die momenteel al kennen voor kunstmeststoffen. Dit kan meer ruimte bieden voor het produceren van kunstmeststoffen van secundaire (gerecyclede) meststoffen zoals de grondstoffen uit afval(-water), compost, digestaat, dierlijke mest en andere dierlijke bijproducten. Zo kan de Meststoffenverordering het in de toekomst mogelijk maken dat teruggewonnen meststoffen zoals struviet, zonder afvallabel met een CE merk in de EU verhandeld worden. Deze producten verliezen dus hun afvalstatus en bereiken tevens de eindstatus in het kader van de Verordening dierlijke bijproducten, waarmee enkele belangrijke belemmeringen voor hergebruik van deze producten verdwijnen. Onder Nederlands voorzitterschap is een start gemaakt met de behandeling van deze verordening. De verwachting is dat het voorstel in de loop van 2018 zal worden aangenomen. De verruiming van de reikwijdte van deze Meststoffenverordening naar deze nieuwe bemestingsproducten en de mogelijkheid om daar reststromen voor te gebruiken maakt Nederland minder afhankelijk van fossiele grondstoffen (zoals aardgas, fosfaat of kalium), waarvan sommige door de Commissie zijn aangeduid als kritiek. Daarnaast kunnen organische meststoffen een positieve bijdrage leveren aan het verhogen van het organische stofgehalte in de Europese bodems.

Nutriënten platform

In samenwerking met het Nutriënten Platform werkt het kabinet aan het creëren van een Europese en mondiale markt voor gerecyclede nutriënten in een duurzame landbouw, waarbij kennisuitwisseling en ontwikkeling rond duurzame innovaties en het bouwen aan slimme coalities/ partnerschappen centraal staan. Om hier invulling aan te geven, zal blijvend ondersteuning geboden worden aan de uitvoering van de Ambitie Nutriënten 2018 van het Nutriënt Platform (een bredere agenda waarin ook gekeken wordt naar de relatie met micronutriënten, organische stof (humuszuur) en bodemverbetering). Dit wordt onder andere ingevuld met:

- $\quad$ Een verkenning naar mogelijkheden en kansen voor recycling en duurzaam hergebruik van andere nutriënten dan fosfaat en organische stof;

- Mogelijke aanvullende effectieve beleidsmaatregelen gericht op het substantieel vergroten van het gebruik van gerecyclede nutriënten. Op internationaal niveau blijft het kabinet investeren in het versterken van het European Sustainable Phosphorus Platform en het Global Partnership on Nutrient Management. Daarnaast zal worden gewerkt aan de uitvoering en verdere ontwikkeling van internationale Green Deals gericht op het bevorderen van een internationale markt voor gerecylede nutriënten.

Tevens zet het kabinet in op de ontwikkeling van internationale Green Deals gericht op het combineren van gebalanceerde precisiebemesting en nutriënten kringloopsluiting en ondersteuning van de circulaire landbouw in Oost- en Zuid-Europa. 


\title{
5.6 Conclusies van de commissie Nijpels (Toekomst van de Veehouderij)
}

\section{Veehouderij als producent van mineralen en organische stof.}

\author{
Tekst overgenomen uit samenvatting rapport.
}

Mest als product wordt momenteel ondergewaardeerd in Nederland: een deel wordt afgezet op eigen land binnen de daarvoor geldende regels, het 'bedrijfsoverschot' wordt elders als een afvalproduct verwerkt. De waarde van mest kan beter worden verzilverd als het wordt opgewerkt tot specifieke producten die een marktwaarde hebben. Zo is de landbouw gebaat bij een circulair agro-ecosysteem waarin het organische materiaal en mineralen uit mest in gescheiden vorm zo hoogwaardig mogelijk worden benut, als bodemverbeteraar respectievelijk kunstmestvervanger of voedingsadditief. Of om zo extra koolstof in de bodem vast te leggen, als bijdrage aan de mitigatie van broeikasgassen. Terwijl mest als afvalproduct op dit moment grote milieudruk oplevert kan de grondstof mest het vierde product van de veehouderij worden, naast melk, eieren en vlees. De producten uit mest moeten dan wel aan hoge kwaliteitseisen voldoen. Dit stelt randvoorwaarden aan opvang, transport en behandeling van mest in de veehouderij en de verwerkingsketen.

Het kabinet heeft recent in de Rijksbrede Visie Circulaire Economie aangegeven dat bestaande (inter)nationale mestregelgeving aangepast zal moeten worden om te voldoen aan de eisen die de circulaire economie stelt. Het kabinetsbeleid is erop gericht om de Nederlandse economie in 2030 voor 50 procent circulair te laten zijn en voor 100 procent in 2050.

Met de volgende aanbevelingen beoogt de commissie de stappen op weg naar een circulaire economie met grotere urgentie te zetten en de hoogwaardige benutting van mest te versnellen:

- Mestopwerking tot producten met een marktwaarde dient de nieuwe standaard te worden. De overheid dient opwerking van mest, tot marktwaardige producten volgens de best beschikbare technieken, verplicht te stellen voor het zogenaamde "bedrijfsoverschot" en de sector dient te bevorderen dat de mest die binnen het bedrijf blijft, zo hoogwaardig mogelijk wordt benut.

- Om de ontwikkeling van de nationale en internationale markt voor hoogwaardige mestproducten te bevorderen is het nodig dat overheid en sector een systeem voor kwaliteitsborging van mest ontwikkelen, bijvoorbeeld door aanscherping van de bestaande certificering voor meststoffen. Het aankopen van mest die niet aan deze kwaliteitseisen voldoet, moet met een milieuheffing worden ontmoedigd.

- Om een stabiele markt voor hoogwaardige mestproducten te borgen, zijn meerjarige afspraken over afzet van mest als grondstof in binnen- en buitenland cruciaal. Daarbij dienen de eisen die de markt stelt aan de functionaliteit van hoogwaardige organische fracties uit mest (vezels, compost, aarde, bacteriële biomassa, et cetera) voor bodemverbetering en industriële toepassingen verder te worden gespecificeerd.

- $\quad$ Regelgeving die meststoffen van dierlijke oorsprong nadelig in de afzet maakt ten opzichte van gelijkwaardige meststoffen van gemijnde grondstoffen moet worden aangepast. De positieve lijst van toegestane producten moet vanuit oogpunt van circulariteit worden uitgebreid.

- Technieken om hoogwaardig organisch materiaal uit mest te winnen, bij voorkeur gescheiden van de minerale fractie (met name fosfaat, stikstof, kalium en zink) die daarbij als afzonderlijke bijproducten worden gewonnen, moeten versneld worden opgeschaald. De commissie adviseert de overheid hiervoor een stimuleringsregeling in te richten.

Er dient een nationaal innovatieprogramma met publiek-private financiering te komen om de omslag naar mest als grondstof in een circulaire economie en een neutrale fosfaat balans te maken. Daarbij moet ook worden gekeken naar beïnvloeding van de mest kwantiteit en kwaliteit via geraffineerde diervoeders die beter door de dieren worden benut. 


\subsection{Biologische landbouw}

\section{Jan de Wit, Louis Bolk Instituut.}

In het kader van de "Kringlooptoets" over mestverwerking en gelijktijdig uitbannen van het kunstmestgebruik kwam de vraag op in hoeverre dit een stimulans is voor de omschakeling naar biologische landbouw (document "Vragen mestverwerking workshop 20170517"). Concreet:

1. Hoe zit het met de omschakeling naar biologisch? Hoeveel ruimte is er in de markt, is er inderdaad vraag naar? Wat betekent een sterke groei voor de prijzen in die sector?

2. Kan de omschakeling naar biologisch zomaar plaatsvinden? Verwerkte producten uit dierlijke mest zijn niet automatische biologische mest? Omschakeling naar biologische veehouderij vereist biologische voedergrondstoffen.

Hierover kan in algemene zin het volgende gezegd worden:

- De omvang van de biologische productie is beperkt. In Nederland was dit in 2015 ruim $3 \%$ van het productieareaal. Een belangrijk deel van de biologische AGF, zuivel en eieren wordt geëxporteerd, vooral naar Duitsland (Bio-monitor 2015).

- $\quad$ Ook het marktaandeel in de consumentenuitgaven bedroeg ruim 3\% (m.n. eieren, AGF en zuivel). Deze markt is groeiende, ook internationaal, met naar verwachting met $10-15 \%$ per jaar (zoals dit eigenlijk al decennialang gaat met soms tijdelijke versnellingen of vertragingen), maar zal i.i.g. nog jaren een (grote) nichemarkt blijven (Bio-monitor 2015).

- Grootschalige omschakeling op korte termijn is vanuit de afzet bezien onmogelijk of geeft aanleiding tot grote prijsdalingen. Een dergelijke prijsdaling was bijvoorbeeld het geval in periode rond 2000-2005 toen het aanbod (door omschakelingssubsidies) harder groeide dan de vraag. In de afgelopen 2 jaar hebben de zuivelverwerkers in Nederland dit voorkomen door een aannamestop in te voeren: de interesse in omschakeling was (als gevolg van de zeer slechte gangbare melkprijzen) veel groter dan de verwachtte vraag.

- Grootschalige omschakeling (> paar procent van de huidige gangbare agrariërs) is ook vanuit de productiekant onwaarschijnlijk: naast een verbod op kunstmest zijn er allerlei andere bepalingen van kracht in de biologische landbouw die een belangrijk knelpunt vormen voor daadwerkelijke omschakeling, bijv. het verbod op gewasbeschermingsmiddelen, de noodzaak tot uitloop/beweiding en biologische herkomst van inputs, bijv. veevoer (vrijwel 100\%) en mest. Dierlijke mest vanuit de gangbare veehouderij is slechts voor een beperkt deel bruikbaar in de biologische landbouw. Er diverse regels maar belangrijkste zijn dat mest uit de gangbare intensieve veehouderij niet gebruikt mag worden, dat een stijgend aandeel (nu 65\% van de mest op akkerbouw- en tuinbouwbedrijven) van biologische herkomst moet zijn en dat in de verwerking geen verboden chemische stoffen mogen worden gebruikt (met soms tijdelijke uitzonderingen).

Voor de verschillende sectoren kan deze verwachting (dus afgezien van afzet- en prijsontwikkelingen) nog wel iets gespecificeerd worden:

- Akker- en tuinbouw: een algemeen verbod op kunstmest zal de interesse in omschakeling doen stijgen, maar de daadwerkelijke omschakeling wordt vooral beperkt door het verbod op gewasbeschermingsmiddelen en de mede daaruit voortvloeiende noodzaak tot ruimere vruchtwisselingen; 1 -op- 6 is gebruikelijk in de bio-sector, wat grote aanpassingen en (des)investeringen vergt ten opzichte van de huidige situatie in de gangbare akker- en tuinbouw. Een plotselinge stijging van deze bio-sector en dus een plotselinge stijging van de vraag naar biomest, als gevolg van een algemeen verbod op kunstmest, is dus onwaarschijnlijk.

- Melkveehouderij: door een algemeen verbod op kunstmest zal de interesse in omschakeling sterk groeien (overige bepalingen zijn minder ingrijpend), maar ook bij goede afzetprijzen is dit bedrijfseconomisch zelden interessant voor intensievere bedrijven (grofweg $>14.000 \mathrm{~kg}$ melk per ha). Dit kan verbeteren indien de vraag naar biologische mest groter wordt (wat onwaarschijnlijk is, zie hiervoor), maar wordt beperkt door een gelijktijdig knelpunt in de ruwvoervoorziening. Of de voorziening (en prijs) van biologische krachtvoergrondstoffen een knelpunt wordt is moeilijk te voorzien want sterk afhankelijk van mondiale ontwikkelingen (en regelgeving omtrent bijv. geografische herkomst); bij werkelijk grootschalige omschakeling wel waarschijnlijk.

- Pluimvee- en varkenshouderij: ondanks dat ook biologische pluimvee- en varkensbedrijven een groot deel van hun mest afzetten naar de biologische akker- en tuinbouw, zijn deze sectoren 
weinig gevoelig voor veranderende mestvraag en -prijzen; ze reageren vooral op de (internationale) prijzen voor voer en eieren/vlees. Daarnaast wordt omschakeling ook (sterk) beperkt door de bestaande infrastructuur op de gangbare bedrijven waar bijv. uitloop moeilijk / niet te realiseren valt.

Kortom,

- T.a.v. vraag 1: er is ruimte voor groei in de afzetmarkt, maar dit betreft niet meerdere procenten van de huidige gangbare agrariërs. Bij plotselinge grootschalige omschakeling zullen de afzetprijzen (de facto) sterk vergelijkbaar worden met de huidige gangbare prijzen, waarmee het bedrijfseconomisch resultaat sterk negatief zou worden.

- T.a.v. vraag 2: er zijn veel meer relevante bepalingen en aandachtspunten bij de omschakeling naar biologische landbouw en verwerkte dierlijke mest zal moeilijk toepasbaar zijn in de biologische akker- en tuinbouw (zowel vanwege mogelijke middelen als vanwege de herkomst). 


\subsection{Broeikasgasemissies mestverwerking}

Vraag: Wat zijn de gevolgen van het stoppen met kunstmest voor de carbon footprint (CFP) van producten?

Blonk Consultants, Hans Blonk en Jasper Scholten

Tabel 1. Samenvattend antwoord (Bij ongewijzigde consumptie in Nederland en het buitenland)

Effect product carbon footprint Nederlandse productie Buitenlandse productie

\begin{tabular}{lcc} 
Akkerbouwgewassen & CFP daalt met $10 \%$ à $20 \%$ & CFP stijgt \\
\hline Zuivel & CFP stijgt & Weinig verandering - wellicht lichte \\
& & stijging van CFP
\end{tabular}

\section{Relevante mechanismen}

Naast de bevindingen van de workshop van 17 mei zijn onderstaande mechanismen van belang in de beantwoording van vraag:

Bijdrage van kunstmestproductie aan de carbon footprint

Het effect op de carbon footprint zal voornamelijk worden veroorzaakt door de shift van $\mathrm{N}$-kunstmest naar $100 \% \mathrm{~N}$ uit organische mest. Dit heeft te maken met het feit dat ongeveer $30 \%$ van de milieuimpact van Nederlandse gewassen wordt veroorzaakt door de productie van kunstmest en in mindere mate de emissie van fossiele $\mathrm{CO}_{2}$ door de toepassing van ureum (zie figuur 2). De bijdrage/productie van $\mathrm{P}$ en $\mathrm{K}$-meststoffen op de totale footprint is relatief laag.

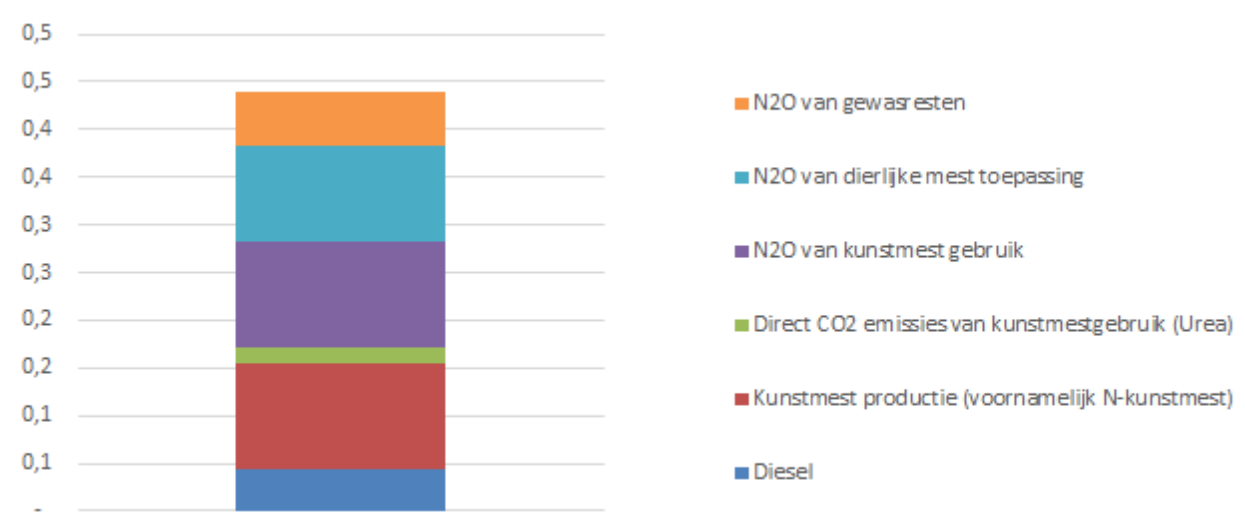

Figuur 1. Carbon footprint van $1 \mathrm{~kg}$ gangbare tarwe geteeld in Nederland (kg CO2-eq. / kg tarwe). Let op: De dierlijke mest die wordt toegepast is onverwerkt. Bron: Agrifootprint 2.0 (Wheat grain, at farm/NL Economic).

Indirect land use change / ontbossing

De verwachting is dat opbrengsten op peil kunnen blijven. Maar als de opbrengsten toch dalen door het niet geheel kunnen compenseren van kunstmest en bij ongewijzigde voedselpatronen in Nederland en buitenland, zal er wereldwijd meer druk komen op het beschikbare land met ontbossing tot gevolg (en bijbehorende $\mathrm{CO}_{2}$ emissies door (in)direct Land Use Change). Het gevolg voor Nederland is dat de carbon footprint van geïmporteerde agri-food producten (fruit, mengvoer) zal stijgen.

Stijging eiwitrijke brok in rantsoen melkkoeien

De verwachting is ook dat de energie- en eiwitvoorziening uit eigen gewassen op peil kan blijven. Maar als dat niet het geval is, zal de eiwitrijke fractie (o.a. sojameel) in het krachtvoer toenemen met $\mathrm{CO}_{2}$ emissies door ontbossing tot gevolg wat resulteert in een stijging van de carbon footprint van zuivelproducten door toenemende hoeveelheid mengvoederproductie elders met toenemend landgebruik of toenemende intensivering (hogere kunstmestinput) elders. 
Data-gap: Carbon footprint van organische meststoffen / mestverwerking

Het lijkt vanuit figuur 1 dat een shift naar organische meststoffen een reductie in CFP veroorzaakt echter:

wordt er in dit voorbeeld niet verder bewerkte dierlijke mest toegepast. De vraag is of de carbon footprint van mestverwerking en/of organische meststoffen opweegt tegen de carbon footprint van kunstmest omdat er sprake isforse energie-inputs voor mestverwerking voor drogen en hygiëniseren (er is hierover nog weinig literatuur beschikbaar).

- Wanneer naar productiesystemen wordt gekeken in Nederland die geen kunstmest gebruiken en ook geen synthetische gewasbeschermingsmiddelen (biologisch) dan daalt de carbon footprint per eenheid product in Nederland (zie figuur 2) maar zal er minder opbrengst per ha zijn waardoor de carbon footprint van een product in het buitenland zal stijgen door toenemend kunstmestgebruik of landgebruik aldaar.

- Dit geldt niet voor systemen die alleen dierlijke mest gebruiken en wel pesticiden. Hier is het waarschijnlijk dat de nitrogen use efficiency in de teelt zal dalen waardoor er per eenheid productie meer $\mathrm{N}$ wordt gebruikt wat ook weer tot een verhoging leidt van de carbon footprint, maar waarschijnlijk nog steeds een verbetering geeft ten opzichte van systemen met gemengd kunstmest en dierlijke mestgebruik. Overigens is het ook weer waarschijnlijk dat bij schaarste van dierlijke mest de toepassing meer efficiënt zal worden in vergelijking met de huidige situatie.

Figuur 2 bevat een meer zuivere vergelijking tussen gangbare en biologische tarwe waarbij er rekening is gehouden met een verminderde gewasopbrengst (+/- 25\%) en identieke stikstofefficiëntie (Bron = Rapport voor PBL, nog te publiceren in 2017). De organische mest die wordt toegepast bij de biologische tarweteelt is onverwerkt (door databeperkingen / onzekerheden omtrent mestverwerking). De milieu-impact van de productie van kunstmest vs bewerkte organische meststoffen (deels vertrouwelijk) laat weinig verschil zien.

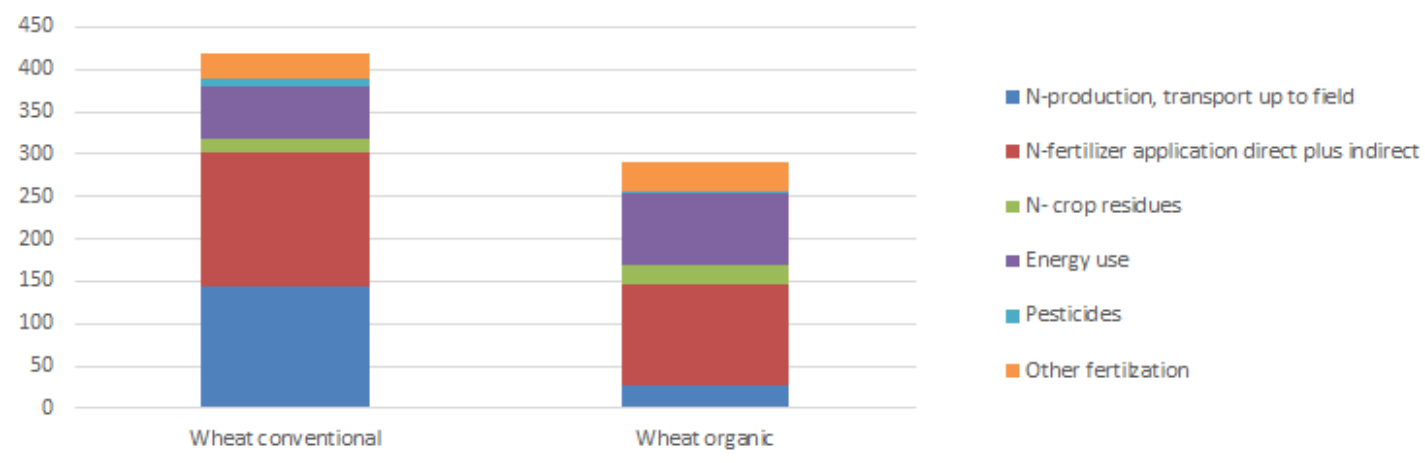

Figuur 2. Carbon footprint vergelijking tussen gangbare en biologische tarwe ( $\quad$ C CO2-eq/kg tarwe).

\section{Groenbemesters}

Mogelijk zullen meer vlinderbloemigen als leverancier van $\mathrm{N}$ worden ingezet in de akkerbouw en in grasland. Echter kunnen groenbemesters een stijging van $\mathrm{N}_{2} \mathrm{O}$ emissies veroorzaken - vnl. als leguminosen worden toegepast (Basche, Miguez, Kaspar, \& Castellano, 2014).

\section{Milieu- en landbouwkundige kengetallen meststoffen}

Een waardevolle studie omtrent milieu en meststoffen is Dekker et al (2009). Onderstaand wordt de samenvatting per $\mathrm{kg} \mathrm{N}$ weergegeven. De methaanslip van mestvergisting zijn in deze studie echter voor $100 \%$ gealloceerd naar biogas i.p.v. ook een deel naar het digestaat. Deze aanname is niet meer houdbaar wanneer de economische waarde van organische meststoffen stijgt omdat kunstmest niet meer mag worden toegepast. 
Tabel 2-samenvatting. Kengetallen uitgedrukt per kg N-totaal in de meststof.

Samenvatting van de milieu- en landbouwkundige kengetallen voor de verschillende meststoffen uitgedrukt per kg N-totaal in de meststof. Fase 1 zijn berekeningen tijdens het productieproces van de meststof en het transport naar de akkerbouwer. Fase 2 zijn berekeningen op de akker voor zover het de bemesting betreft. Fase 0 betreft de mestvergisting gericht op de productie van biogas.

\begin{tabular}{|c|c|c|c|c|c|c|c|c|}
\hline & Fase & $\begin{array}{c}\text { GFT- } \\
\text { compost }\end{array}$ & $\begin{array}{c}\text { Vaste } \\
\text { runder- } \\
\text { mest }\end{array}$ & $\begin{array}{l}\text { Rundvee } \\
\text { drijfmest }\end{array}$ & Digestaat & $\begin{array}{c}\text { Digestaat } \\
\text { effluent }\end{array}$ & $\begin{array}{c}\text { Digestaat } \\
\text { dikke } \\
\text { fractie } \\
\end{array}$ & KAS \\
\hline \multirow[t]{3}{*}{ Energie $(\mathrm{MJ} / \mathrm{kg} \mathrm{N})$} & $\overline{0}$ & 0 & 0 & 0 & -94.1 & -115.3 & -53 & $\overline{0}$ \\
\hline & 1 & 95.3 & 7.3 & 5 & 4.5 & 5.5 & 2.5 & 42 \\
\hline & 2 & 4.3 & 5.8 & 6.1 & 5.5 & 6.8 & 4.3 & 1.1 \\
\hline \multirow[t]{3}{*}{ Emissie $\left(\mathrm{kg} \mathrm{CO}_{2}\right.$-eq/kg N) } & 0 & 0 & 0 & 0 & -12 & -14.8 & -6.8 & 0 \\
\hline & 1 & 13.1 & 14.5 & 12.7 & 10 & 12.3 & 10.6 & 3 \\
\hline & 2 & 5.8 & 10.5 & 10.2 & 8 & 8 & 7.9 & 5.3 \\
\hline $\begin{array}{l}\text { Nitraatuitspoeling }\left(\mathrm{kg} \mathrm{NO}_{3} / \mathrm{kg} \mathrm{N}\right) \text { potentie op } \\
\text { lange termijn }\end{array}$ & 2 & 1.2 & 1.1 & 0.9 & 0.9 & 0.8 & 1 & 0.7 \\
\hline \multirow[t]{2}{*}{ Ammoniakemissie $\left(\mathrm{kg} \mathrm{NH}_{3} / \mathrm{kg} \mathrm{N}\right)$} & 1 & 0.01 & 0.13 & 0.03 & 0.02 & 0.03 & 0.12 & 0 \\
\hline & 2 & 0.02 & 0.04 & 0.06 & 0.08 & 0.09 & 0.07 & 0.04 \\
\hline Transportafstand $(\mathrm{km} / \mathrm{kg} \mathrm{N})$ per 35 ton & 1 & 25.9 & 3.1 & 11.4 & 16.3 & 20 & 9.2 & 0.6 \\
\hline Org. stof afbreekbaar le jaar $(\mathrm{kg} / \mathrm{kg} \mathrm{N})$ & 2 & 5.6 & 7 & 4.3 & 6.9 & 4.3 & 11.8 & 0 \\
\hline Org. stof langzaam afbreekbaar ( $\mathrm{kg} / \mathrm{kg} \mathrm{N})$ & 2 & 16.5 & 16.4 & 10.2 & 7.1 & 4.3 & 12.4 & $\overline{0}$ \\
\hline
\end{tabular}

\begin{tabular}{|c|c|}
\hline \multicolumn{2}{|c|}{ relatieve waardering } \\
\hline ongunstig & 0 \\
$\uparrow$ & $0+$ \\
& + \\
$\downarrow$ & ++ \\
gunstig & +++ \\
\hline
\end{tabular}

\section{Disclaimer}

Er is geprobeerd dit vraagstuk zo goed mogelijk te beantwoorden in de daarvoor gestelde tijd (ongeveer $1 \mathrm{dag}$ ) en oplevering (binnen 1 week) op basis van de reeds aanwezige kennis bij Blonk Consultants in te zetten. Uiteraard moet er zeer zorgvuldig worden omgegaan met het gegeven antwoord gezien de complexiteit van het vraagstuk.

\section{Referenties}

Basche, A. D., Miguez, F. E., Kaspar, T. C., \& Castellano, M. J. (2014). Do cover crops increase or decrease nitrous oxide emissions? A meta-analysis. Journal of Soil and Water Conservation, 69(6), 471-482. https://doi.org/10.2489/jswc.69.6.471

Dekker, P. H. M., Stilma, E. S. C., van Geel, W. C. A., \& Kool, A. (2009). Levenscyclusanalyse meststoffen bij gebruik in de biologische en gangbare landbouw. Blonk Milieu Advies, Gouda. 


\subsection{Kunstmestvervangers en werking}

Gerard Velthof, Wageningen UR, Environmental Research.

De volgende vragen zijn gesteld:

- Hoe zit het met de werkingscoëfficiënten van de concentraten?

- Wat zijn de gevolgen voor uitspoeling en andere emissies?

- Hoe werkt de kunstmestvervanger? Wat is de exacte definitie? Hoe verhoudt het zich tot de regelgeving? Er is argwaan dat het een ontsnappingsroute kan zijn voor meer $\mathrm{N}$ gebruik.

\section{Werkingscoëfficiënten concentraten:}

Potproeven toonden aan dat de netto vervangingswaarde van mineralenconcentraten $91 \%$ bedroeg. De netto vervangingswaarde wordt vastgesteld ten opzichte van kalkammonsalpeter, de meest gebruikte $\mathrm{N}$ meststof in Nederland. The netto vervangingswaarde in de proeven was daarmee gelijk aan de theoretisch berekende waarde. Een deel van de $\mathrm{N}$ is aanwezig in organische vorm en er treedt enige emissie op van $\mathrm{NH} 3$. The netto vervangingswaarde van varkensmest was beduidend lager (gemiddeld $75 \%$ ) dan die van de mineralenconcentraten.

De netto vervangingswaarde van mineralenconcentraten in veldproeven was lager dan in de potproeven, maar de variatie was groot. De vervangingswaarden varieerden van $72-84 \%$ voor bouwland en van $54-81 \%$ voor grasland in de gedetailleerde veldproeven. In eenvoudige veldproeven varieerde de werking van 0 tot $130 \%$. De netto vervangingswaarde varieerde van $54 \%$ in 2009 tot $81 \%$ in 2012. Er is geen verklaring voor de lage waarde in 2009. Als de netto

vervangingswaarde wordt vergeleken met vloeibaar ammoniumnitraat is de werking $79-102 \%$. Dat is een hogere werking dan in de vergelijking met kalkammonsalpeter. De verdeling van de kunstmest is anders voor de kalkammonsalpeter (gestrooid) dan voor de geïnjecteerde vloeibare kunstmest. Dat kan een rol hebben gespeeld in de $\mathrm{N}$ efficiëntie van de beide kunstmestsoorten.

De resultaten wijzen er op date $r$ ruimte is voor verbetering van de netto vervang ingswaarde van mineralenconcentraten door het gebruik van toedieningstechnieken met een lage emissie van $\mathrm{NH} 3$ en door het verlagen van het gehalte aan organische $\mathrm{N}$ van de mineralenconcentraten.

\section{Uitspoeling en andere emissies}

Het risico van nitraatuitspoeling van toegediende mineralen concentraten was gelijk of lager dan dat van kalkammonsalpeter, zowel op grasland als bouwland. Het verlies via uitspoeling was groter voor dierlijke mest (rundvee en varkens) was hoger dan dat van mineralenconcentraten, wat waarschijnlijk wordt veroorzaakt door mineralisatie van organische $\mathrm{N}$ in de dierlijke mest buiten de groeiperiode van het gewas.

Mineralenconcentraten bevatten NH4 met een hoge $\mathrm{pH}$. Daarom is het risico van ammoniak emissie aanwezig (Velthof and Hummelink, 2011; Huijsmans and Hol, 2011). Injectie of inwerken van de concentraten kan de emissie van ammoniak beperken. Scenario studies naar grootschalige productie van mineralenconcentraten laten zien dat de totale emissies van ammoniak nauwelijks veranderen, maar dat de emissies in gebieden met hoge veedichtheden verder zullen toenemen. De aandacht om emissies te reduceren moet dus met name op die gebieden gericht zijn.

Velthof en Hummelink (2011) vonden wel een relatief hoge emissie van lachgas na de toediening van mineralenconcentraten. Zowel nitrificatie als denitrificatie spelen een rol. Hoge ammoniak concentraties in de bodem zullen nitrificatie remmen, terwijl wel N2O wordt gevormd (Chalk en Smith, 1983). De mineralen concentraten bevatten mogelijk vluchtige vetzuren andere beschikbare vormen van koolstof die kunnen leiden tot denitrificatie van nitraat in de bodem na de toediening van de concentraten. 
Scenario studies naar de effecten van grootschalige toepassing van mineralenconcentraten laten nauwelijks enige verandering zien van de emissies van lachgas. Het gebruik van nitrificatie remmers, verzuring en verwijdering van organische $C$ verbindingen uit de mineralenconcentraten zijn mogelijke maatregelen die de lachgasemissie van mineralenconcentraties kan doen afnemen.

\section{Hoe werkt de kunstmestvervanger? Wat is de exacte definitie? Hoe verhoudt het zich tot de} regelgeving? Er is argwaan dat het een ontsnappingsroute kan zijn voor meer $\mathbf{N}$ gebruik.

In de Nitraatrichtlijn wordt een maximum gesteld aan de hoeveelheid dierlijke mest (170 kg N/ha of hoger bij een derogatie). In de Nitraatrichtlijn staan de volgende definities:

- Kunstmest: elke met een industrieel proces vervaardigde meststof;

- Dierlijke mest: excrementen van vee of een mengsel van strooisel en excrementen van vee, alsook producten daarvan.

Het idee bij aanvang van de Pilot Mineralenconcentraten in 2009 was om uit dierlijke mest een kunstmest te maken volgens de definitie van de Nitraatrichtlijn: industrieel vervaardigd. Daarom de eis om omgekeerde osmose toe te passen. Daarnaast moet de werking ook vergelijkbaar zijn als kunstmest. Een mineralenconcentraat blijft ook altijd dierlijke mest (product van dierlijke mest), zodat de Nitraatrichtlijn zou moeten worden aangepast. Een kunstmestvervanger is dus een product dat binnen de Nitraatrichtlijn een kunstmest is en geen dierlijke mest.

Naast de Nitraatrichtlijn speelt ook de EU Meststoffenverordening een rol. Deze reguleert de handel van meststoffen. Deze verordening ligt al jaren onder revisie en mineralenconcentraten voldoen (nog) niet aan de eisen van de voorgestelde verordening. Vanuit de Nitraatrichtlijn is aangegeven dat mineralenconcentraten eerst erkend moet worden in de EU Meststoffenverordening.

Het stikstofgebruik in Nederland wordt gereguleerd door de gebruiksnorm stikstof, uitgedrukt in werkzame N, waarbij kunstmest (en dus mineralenconcentraten) voor $100 \%$ wordt ingerekend en dierlijke mest volgens de werkingscoefficient (bv. $45 \%$ voor rundermest op bedrijven met beweiding). Daarnaast spelen de gebruiksnormen voor fosfaat en dierlijke mest (uitgedrukt in $\mathrm{N}$ ) indirect ook een rol. Door de gebruiksnorm stikstof is er dus geen risico dat er meer stikstof wordt gebruikt indien dierlijke mest wordt omgezet in kunstmest. Aangezien de werkingscoëfficiënt van mineralenconcentraten hoger is dan mest kan de totale hoeveelheid stikstof die wordt gebruikt zelfs afnemen.

Conclusies grootschalige toepassing mineralenconcentraten in NL (Lesschen et al., 2011) (http://edepot.wur.nl/191658)

\section{Effecten op bemesting en export}

Het effect van de productie en toepassing van mineralenconcentraten op het gebruik van meststoffen en op de emissies naar het milieu wordt geïllustreerd door de volgende scenario's te vergelijken (zie ook Tabel 1):

- Ref_2015: geen mineralenconcentraten

- S1: $10 \%$ mineralenconcentraten uit varkensmest

- S2: $50 \%$ mineralenconcentraten uit varkensmest

- S3: $10 \%$ mineralenconcentraten uit varkensmest en 10\% mineralenconcentraten uit rundermest

- S4: 50\% mineralenconcentraten uit varkensmest en 10\% mineralenconcentraten uit rundermest

- S5: 10\% mineralenconcentraten uit varkensmest en 50\% mineralenconcentraten uit rundermest

- S6: 50\% mineralenconcentraten uit varkensmest en 50\% mineralenconcentraten uit rundermest 


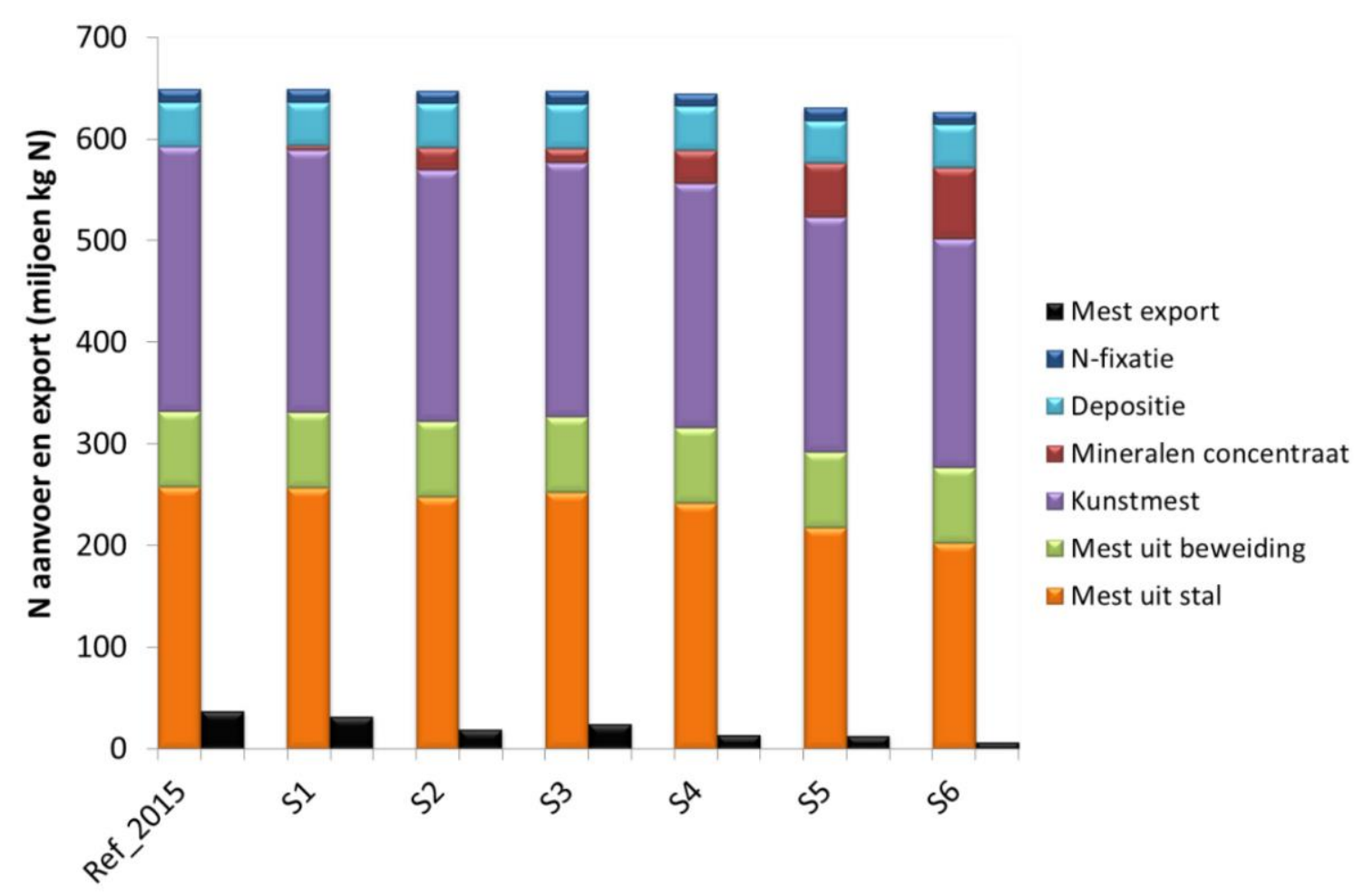

Figuur 19. Stikstofaanvoer naar Nederlandse landbouwgronden en de hoeveelheid varkensmest die wordt geëxporteerd. De post 'N-fixatie' heeft betrekking op biologische stikstofbinding door vlinderbloemigen.

- Figuur 19. Toepassing van mineralenconcentraten leidt tot minder gebruik van (conventionele) stikstofkunstmest en minder export van mest. Omdat wordt aangenomen dat melkveebedrijven geen varkensmest aanvoeren, neemt de totale hoeveelheid stikstof die als mest aan landbouwgronden wordt toegediend in Nederland bij de grootschalige productie van mineralenconcentraten af in S5 en S6.

- In het scenario met toepassing van mineralenconcentraten en dikke fractie is de totale hoeveelheid werkzame stikstof (volgens wettelijke werkingscoëfficiënten) hoger dan in het scenario met onbewerkte mest. Hierdoor wordt er minder kunstmest toegediend en is de totale stikstofaanvoer in scenario's met mineralenconcentraten en dikke fractie lager dan in het scenario met alleen onbewerkte mest.

- Bij grootschalige mestverwerking ontstaat geen ruimte voor een grotere veestapel.

- De scenarioberekeningen laten zien dat grootschalige toepassing van mineralenconcentraten onder de veronderstelde condities voor 2015 (gebruiksnormen 2015, excreties 2009 en huidige derogatie) leidt tot een hogere mestplaatsingsruimte voor mest (waardoor er minder mestexport nodig is). Hierdoor neemt het gebruik van zowel (conventionele) stikstof- als fosfaatkunstmest in Nederland af. 


\subsection{Effecten mestbeleid op organische stof}

Onderstaande tekst is integraal overgenomen uit Velthof et al. (2017), hoofdstuk 6.7. Belangrijkste bevindingen:

- Resultaten van analyses van gehalte aan organische stof in bodemmonsters in de periode 19852015 laten een stabiele tot stijgende trend zien voor grasland, bouwland (akkerbouw) en maïsland. Een nadere analyse van trends in de periode 2005-2015 voor combinaties gewasgroep (grasland, bouwland, akkerbouw) en grondsoort (dekzand, rivierklei, zeeklei, dalgrond, löss en veen en kleiig veen) laat ook geen daling zien en een daling is ook niet zichtbaar indien de trends op het niveau van landbouwgebieden worden geanalyseerd.

- Modelberekeningen laten vaak een negatieve organische stofbalans zien in de akkerbouw; de afbraak is hoger dan de aanvoer. Dit zou moeten resulteren in een daling van het gehalte aan organische stof. Dit is echter niet zichtbaar in de trends van gemeten gehalten aan organische stof. Mogelijke oorzaak hiervoor is het niet rekening houden met rotaties van grasland en bouwland in de modelberekeningen of een overschatting van de in de modellen gebruikte afbraakcoëfficiënten van organische stof in de bodem en in organische meststoffen.

- Het P-Al-getal in landbouwgronden is gemiddeld genomen stabiel gebleven in de periode 20052015. Dit correspondeert met de het feit dat er tot 2014 gemiddeld nog steeds sprake was van een fosfaatoverschot.

- De indicator van het labielste fosfaat $\left(\mathrm{P}-\mathrm{CaCl}_{2}\right)$ laat voor verschillende combinaties van gewasgrondsoort een daling zien; grasland op dekzand en rivierklei, maïsland op rivierklei en akkerbouw op rivier- en zeeklei. $\mathrm{P}-\mathrm{CaCl}_{2}$ is een indicator voor de direct beschikbare fosfaat (intensiteit) in de bodem en reageert snel op bemesting met fosfaat. De lagere fosfaatbemesting door de aangescherpte gebruiksnormen heeft waarschijnlijk geleid tot een daling in deze combinaties gewas-grondsoort. Hierbij moet worden opgemerkt dat gehalten aan $\mathrm{P}-\mathrm{CaCl}_{2}$ waarbij een dalende trend zichtbaar is, landbouwkundig gezien als ruim voldoende tot hoog kunnen worden beschouwd.

- $\quad$ Een eerdere analyse van de dataset geeft aan dat het Pw-getal sinds 1984 tot 2004 is gestegen. De resultaten sinds 2005 laten zien dat het Pw-getal niet meer stijgt en voor sommige gewasgrondsoortcombinaties daalt.

- De stikstoflevering door mineralisatie van organische stof in de bodem (bepaald als de potentiële mineralisatie) is gemiddeld in Nederland iets gedaald in bouwland en iets gestegen in grasland in de periode 2010 en 2015, maar de veranderingen zijn klein. Er lijken nog geen grote veranderingen te zijn in de stikstofmineralisatie in landbouwgronden.

- De beperkte verandering in de gift aan dierlijke mest is waarschijnlijk een belangrijke verklaring voor de geringe verandering in potentiële stikstofmineralisatie tussen 2010 en 2015.

- Gemiddeld nam de opbrengst volgens de oogstramingen van CBS in de periode 2006-2015 jaarlijks met $1,7 \%$ toe op zandgronden en met $1,6 \%$ op kleigrond. Alleen de opbrengststijging van zomergerst en zetmeelaardappelen bleef achter bij de autonome opbrengststijging in rassenproeven. Groentegewassen ontbreken in deze analyse.

- De opbrengst van grasland in Noord- en West-Nederland bleef stabiel in de periode 2006-2014 en steeg significant in Zuid- en Oost-Nederland.

- Ondanks de aanscherping van stikstof- en fosfaatgebruiksnormen en ondanks de daling van de fosfaattoestand in enkele regio's, stegen de gewasopbrengsten op praktijkbedrijven in de periode 2006-2015. Uit de hier geanalyseerde gegevens blijkt dat het mestbeleid in de periode 20062015 gemiddeld genomen niet heeft geleid tot een lagere opbrengst van akkerbouwgewassen, snijmaïs en grasland.

- In de periode 2000-2012 daalden de stikstofgehalten van weidegras en kuilgras significant. In 2013 en 2014 nam het stikstofgehalte in gras weer toe. De aanscherping van stikstofgebruiksnormen heeft waarschijnlijk geleid tot de daling op langere termijn, maar het weer heeft ook een belangrijk effect op het gehalte in een bepaald jaar. Het stikstofgehalte van snijmaïs daalde significant in de periode 2006-2014, wat zeer waarschijnlijk wordt veroorzaakt door de aanscherping van stikstofgebruiksnormen.

- Het gemiddelde fosfaatgehalte van snijmaïs en gras veranderde niet significant tussen 2006 en 2013. Het fosforgehalte in grasland nam toe in 2014, waarschijnlijk door de relatief hoge temperatuur in het voorjaar. De aanscherping van de fosfaatgebruiksnormen zijn (nog) niet zichtbaar in het fosfaatgehalte van snijmaïs en gras.

- Veeljarige veldproeven laten zien dat de bodem veel fosfaat nalevert. Over langere tijd, enige tientallen jaren, blijft de fosfaattoestand bij evenwichtsbemesting op een afdoende peil. 


\subsection{Kostprijs en consumenten respons}

Willy Baltussen en Marieke Meeusen, Wageningen Economic Research.

De gestelde basisvragen aan Wageningen Economic Research zijn:

1. De verwachting is dat de kostprijs van veel producten (met name plantaardige en zuivel) zal stijgen. Wat is de reactie van de NL consument op die prijsstijging?

2. De verwachting is dat de kostprijs van veel producten zal stijgen, wat zijn de gevolgen voor de export?

3. Is er nog ruimte voor bulkproductie in de intensieve veehouderij?

\section{Ad 1: reactie van NL consument op kostprijsstijging van producten}

Het is goed om te realiseren dat vrijwel producten die in Nederland geproduceerd worden de Europese Unie als basisafzet markt hebben en soms zelfs breder namelijk de wereldmarkt (bijvoorbeeld kaas). Zie hiervoor actuele informatie op agrimatie > sector $>$ handel en afzet. (voorbeeld melkvee : http://www.agrimatie.nl/SectorResultaat.aspx?subpubID=2232\&sectorID=2245\&themaID=2276 ).

Een beperkte kostprijsstijging in Nederland (zie Hoste (2017) http://edepot.wur.nl/412970 voor varkens en van Horne (2017) http://edepot.wur.nl/404949 voor pluimveevlees) heeft geen enkel effect op de prijsvorming op de korte termijn. In een studie voor de autoriteit consument en markt (ACM) in 2014 blijkt hoe prijzen in de keten tot stand komen (https://www.acm.nl/nl/zoekresultaat/?zf[]=qu\%3Aprijsvorming\%20voedsel\%202014 ). Deze studie bevestigt de uitkomsten uit eerdere studies in 2004 en 2009. Een beperkte kostprijsstijging zal vooral ten koste gaan van de inkomens van primaire ondernemers. Mochten deze ondernemers stoppen met de productie dan zal er substitutie van NL producten door producten uit andere landen zal plaatsvinden (dit proces duurt wel even want voor veel producten in akkerbouw, melkveehouderij en intensieve veehouderij in Nederland een grote netto exporteur (zie link naar agrimatie in het bovenstaande).

Kortom een paar cent kostprijsstijging van melk en akkerbouwproducten vertaalt zich niet of nauwelijks in een consumentenreactie. Het grootste effect voor de akkerbouwer is dat ze geen geld meer krijgen voor het toedienen van dierlijke mest en dat ze moeten betalen voor de mineralen. De keerzijde zal zijn dat intensieve veehouders veel minder voor de afzet van mest hoeven te betalen en dus een kostprijsverlaging zullen hebben. Een tweede mogelijk grote impact zou kunnen zijn dat de opbrengsten per ha sterk gaan dalen als gevolg van het ontbreken van kunstmest. Maar de verwachting is dat er niet of nauwelijks opbrengstdalingen zullen optreden.

De bereidheid van consumenten om alleen voor milieuzaken (geen gebruik van kunstmest) te betalen moet niet al te hoog ingeschat worden. Literatuur hierover is niet direct voorhanden maar het is minder dan biologisch en de aaibaarheidsfactor is een stuk kleiner dan bij dierenwelzijn. Recent is wel onderzoek gedaan naar de waarde van herkomstinformatie van varkensvlees (http://edepot.wur.nl/405712).

\section{Ad 2. Kostprijsstijging vertaalt zich in een slechtere concurrentiepositie.}

De concurrentiepositie van veel gewassen zoals aardappelen, uien en suikerbieten is positief t.o.v. het buitenland. Dit geldt ook voor melkproductie en intensieve veehouderij. Het gevolg zal zijn dat de akkerbouwers en veehouders iets minder inkomen hebben maar niet dat de productie zal dalen. Een tweede sterke aanwijzing dat de concurrentiepositie van de NL akkerbouwers en veehouders goed is betreffen de prijzen die ondernemers bereid zijn te betalen voor grond en productierechten (http://www.boerderij.nl/landbouwgrond/grondprijzen/?gebied=2507\#pricescontent). Bij de melkveehouderij zal mogelijk de prijs van fosfaatrechten dalen en voor de akkerbouwers de waarde van de grond. In mijn verwachting zal de productie niet of nauwelijks veranderen en dus ook niet de exportpositie. 
Ad 3. Ruimte voor bulkproductie in de intensieve veehouderij.

In de Nederlandse intensieve veehouderij blijft ruimte voor 'bulkproductie' (lees: productie met een pure kostprijsoriëntatie). Dit laat onverlet dat deze productie zich ook ontwikkelt als gevolg van verschillende maatschappelijke ontwikkelingen. Legbatterijen zijn afgeschaft, RTRS is ingevoerd (http://www.responsiblesoy.org/?lang=en), de kip van morgen, varken van morgen zijn geïntroduceerd in de markt. Dit lijken niche producten maar kunnen de bulkproducten van de toekomst gaan vormen. We komen vaak niet verder dan 30\% van markt voor producten met een specifieke marktoriëntatie (Biologisch, milieuvriendelijk, diervriendelijk, meerwaarde consument (knuffelwaarde) etc.). Hierbij speelt ook een rol dat we een groot deel van de geproduceerde producten in het buitenland afzetten en dat retailers daarnaast producten uit het buitenland kopen. Bijvoorbeeld de productie van varkensvlees in Nederland is $1.3 \mathrm{mln}$ ton in 2014 , er wordt respectievelijk $0.3 \mathrm{mln}$ ton vlees geïmporteerd, $0.9 \mathrm{mln}$ ton vlees geëxporteerd en $0.7 \mathrm{mln}$ ton vlees geconsumeerd (zie http://www.agrifoodnieuws.nl/bestanden/agrifoodnieuws/nwsbrf30/2016-

013_Baltussen_DEF_20160125.pdf figuur 1.3). Stel dat we alles wat we niet exporteren duurzaam maken dan is nog steeds meer dan tweederde deel 'bulk'. In de genoemde referentie is ook voor zuivel en aardappelen een dergelijk overzicht weergegeven. 


\subsection{Nationale mineralenbalansen}

De hoeveelheden $\mathrm{N}, \mathrm{P}$ en $\mathrm{K}$ in import en export van landbouw- en andere producten en het balansoverschot voor de drie nutriënten. Basisjaar is 2009.

\begin{tabular}{|c|c|c|c|c|c|c|}
\hline \multirow{2}{*}{$\begin{array}{l}\text { Alle hoeveelheden in miljoen kg } \\
\text { Product }\end{array}$} & \multicolumn{2}{|c|}{$\mathrm{K}$ balans } & \multicolumn{2}{|c|}{$\mathrm{N}$ balans } & \multicolumn{2}{|c|}{ P balans } \\
\hline & Import & Export & Import & Export & Import & Export \\
\hline Dierlijke producten (melk, vlees) & 15 & 20 & 140 & 203 & 11 & 28 \\
\hline Akkerbouwproducten food & 36 & 33 & 116 & 75 & 17 & 10 \\
\hline Akkerbouw producten feed & 22 & - & 73 & - & 12 & \\
\hline Akkerbouwproducten non food & 2 & 7 & 3 & 6 & 0 & 1 \\
\hline Mengvoer grondstoffen & 139 & & 308 & & 39 & \\
\hline Voeradditieven & & & & & 7 & \\
\hline Minerale meststoffen & & & & & 21 & \\
\hline Organische mest & & 93 & & 101 & & 7 \\
\hline Wasmiddelen & & & & & 1 & \\
\hline Afvalproducten & & & & & & 3 \\
\hline totaal & 214 & 153 & 640 & 385 & 108 & 49 \\
\hline Balans overschot & & 61 & & 255 & & 59 \\
\hline
\end{tabular}

De $\mathrm{P}$ balans is ontleend aan de publicatie van Smit et al. (2015). De N en K balansen zijn afgeleid van de $\mathrm{P}$ balans door de N/P en de K/P verhoudingen ten opzichte van de $\mathrm{P}$ gehalten van de verschillende producten te nemen. De cijfers zijn gebaseerd op de volgende bronnen:

- $\quad$ Land- en tuinbouwcijfers 2007. uitgave LEI en CBS.

- Database van CBS op www.cbs.nl.

- C van Bruggen. Dierlijke mest en mineralen 2011. CBS/WUM. (CBS website).

- P Kemme, J. Heeres-vanTol, G. Smolders, H. Valk en J.D. vd Klis. Schatting van de uitscheiding van stikstof en fosfor door diverse categorieën graasdieren. ASG rapport 05/I00653.

- Vee, Vlees en Eieren in Nederland, 2008. www.pve.nl.

- CVB tabellen boek, productschap veevoeder.

- Foodsel.com (voor humane voedermiddelen zoals vlees).

In onderstaande tabellen zijn de verhoudingen tussen $\mathrm{N}$ en $\mathrm{P}$ en $\mathrm{N}$ en $\mathrm{K}$ weergegeven. De $\mathrm{N}$ en $\mathrm{K}$ gehalten zijn berekend aan de hand van het $P$ gehalte en respectievelijk de N/P en de K/P ratio.

\begin{tabular}{|c|c|c|c|c|c|}
\hline melk+melkproducten & $\begin{array}{l}\text { K- } \\
\text { gehalte }\end{array}$ & $\begin{array}{l}\mathrm{K} / \mathrm{P} \\
\text { ratio }\end{array}$ & N-gehalte & $\begin{array}{l}\text { N/P } \\
\text { ratio }\end{array}$ & P-gehalte \\
\hline melk & 1.5 & 1.6 & 5.5 & 5.7 & 1.0 \\
\hline kaas & 1.5 & 0.2 & 50.4 & 7.3 & 6.9 \\
\hline Condens* & 3.1 & 1.6 & 11.3 & 5.7 & 2.0 \\
\hline volle melkpoeder* & 15.6 & 1.6 & 56.2 & 5.7 & 9.9 \\
\hline magere melkpoeder* & 15.5 & 1.6 & 55.8 & 5.7 & 9.9 \\
\hline Room* & 2.4 & 1.6 & 8.4 & 5.7 & 1.5 \\
\hline
\end{tabular}

* KP en NP ratio gelijkgesteld aan melk 


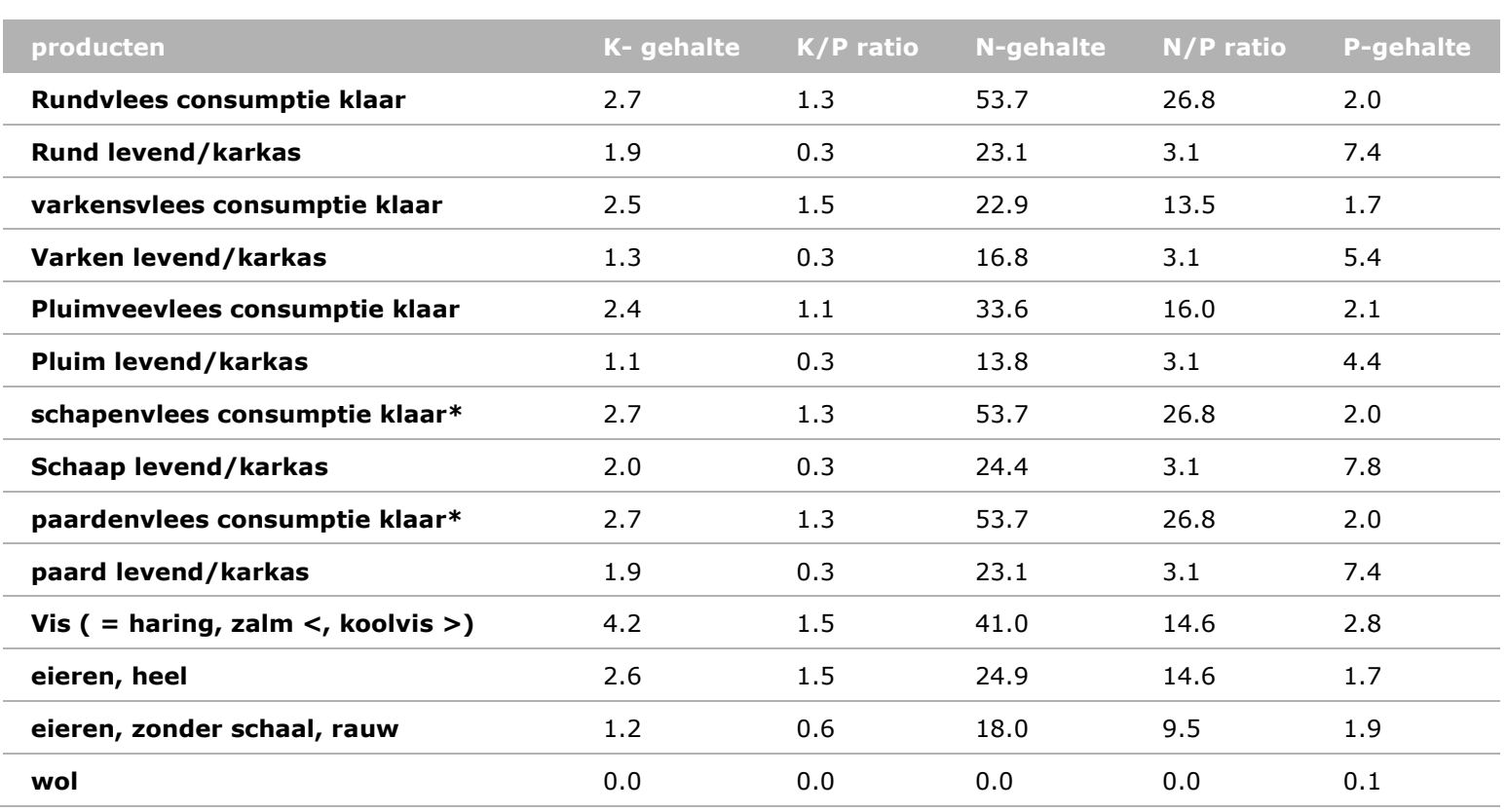

* KP en NP ratio gelijk gesteld aan rundvlees

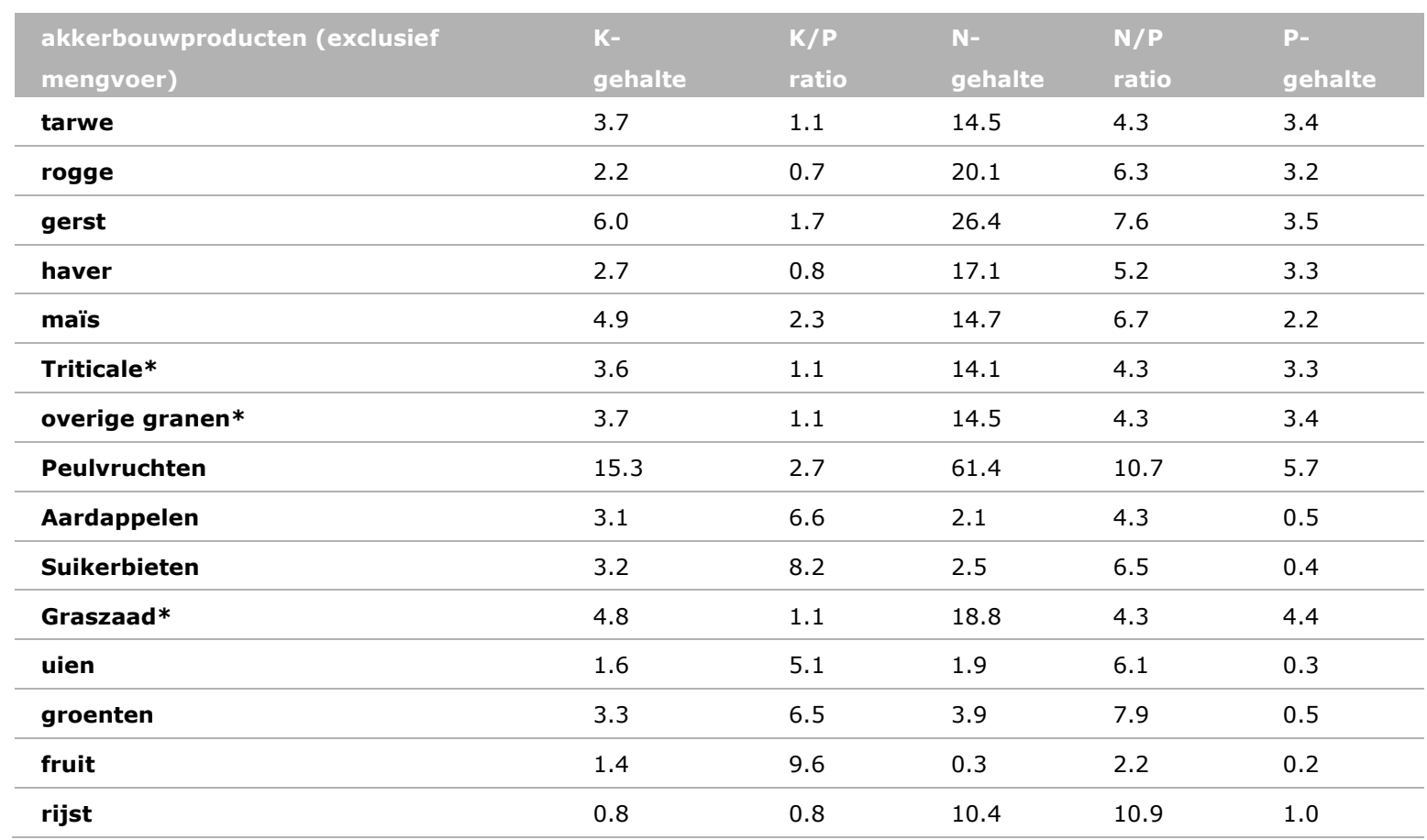

* KP en NP ratio gelijk gesteld aan tarwe

\begin{tabular}{llllll}
\hline Mengvoer totaal & K- & K/P & N- & N/P & P- \\
& gehalte & ratio & gehalte & ratio & gehalte \\
\hline Mengvoer P uit import & 139.2 & 3.1 & 308.6 & 6.9 & 44.4 \\
\hline P toegevoegd totaal (voederfosfaat) & 0.0 & 0.0 & 0.0 & 0.0 & 8.5 \\
\hline
\end{tabular}




\section{Bijlagen met betrekking tot het proces}

\subsection{Leerpunten voor de KringloopToets}

\subsubsection{Het proces gedurende de workshops}

De KringloopToets is in ontwikkeling. $\mathrm{Er}$ is (nog) geen vastomlijnd programma of script voor het uitwerken van een casus met de KringloopToets. Dat wordt werkende weg ontwikkeld. Dat betekent ook dat werkwijzen worden uitgeprobeerd. Omdat het in deze KringloopToets niet alleen gaat over de leereffecten bij de deelnemers en de uiteindelijke resultaten, maar ook over de doorontwikkeling van het instrument, zijn in deze paragraaf een aantal reflecties op het proces opgenomen.

De KringloopToets als instrument wordt door deelnemers ervaren als inspirerend; een goede methode om tot een systematische verkenning te komen; een mooi hulpmiddel om tot nieuwe, onverwachte inzichten te komen; en een werkwijze die helpt om buiten de lobbysfeer te blijven. Ook het projectteam zelf ziet op verschillende punten belangrijke verbeteringen ten opzichte van de eerste KringloopToets die in 2016 in Brabant is uitgevoerd. Er is meer focus gegeven aan discussies, zodat partijen gerichter en doeltreffende het gesprek met elkaar aan gingen. Ook waren het programma en de werkvormen over het algemeen meer afgebakend, zodat discussies efficiënt verliepen en goede diepgang hadden.

Tegelijkertijd zijn er ook een aantal aspecten waar dingen beter hadden gekund. Die worden hieronder nader toegelicht:

- de aanwezigheid - en vooral afwezigheid - van deelnemers;

- doel en resultaten van de KringloopToets;

- $\quad$ een werkvorm om tot conclusies te komen;

- breder uitdragen van de resultaten.

\section{Aanwezigheid van deelnemers}

Er is een brede groep stakeholders uitgenodigd, landbouworganisaties, ketenpartijen, overheden, milieuorganisaties. Allen zijn benaderd met een combinatie van persoonlijke contacten en elektronische berichten. De deelname van een aantal stakeholders was erg enthousiast, met aanwezigheid in alle bijeenkomsten en het zorgen voor vervanging, indien nodig. Anderen waren slechts beperkt aanwezig of afwezig.

Het volledig ontbreken van de akkerbouwsector en het grotendeels ontbreken van de veehouderijsector bij de workshops in deze casus was opvallend. Het kan te maken hebben met de uitnodigingen, die in overleg met de opdrachtgevers op de landbouworganisaties gericht waren en het roerige politieke klimaat waarin met name de melkveehouderijsector zich bevindt, maar met de kennis van nu was meer energie en mogelijk gericht uitnodigen in beide sectoren te prefereren geweest. Hun bijdrage is node gemist. Als voorbeeld kan dienen dat in de casus "geen kunstmest" geen problemen zijn benoemd bij teelt van gewassen (behalve een mogelijk lagere bemesting met $N$ ) of bij de acceptatie van verwerkte producten. Met name de akkerbouw binnen en buiten Nederland is een markt voor verwerkte mestproducten.

Dit een leerpunt voor de volgende keer. Er moet nog meer aandacht worden besteed aan het realiseren van een brede deelname. Maar deelname is op basis van vrijwilligheid en dus niet volledig stuurbaar. Niet iedereen die is uitgenodigd voor de bijeenkomsten is gekomen, terwijl een aantal van hen wel had toegezegd. 


\section{Doelen en resultaten uit de KringloopToets}

Belangrijke zoektocht binnen de doorontwikkeling van de KringloopToets is om de resultaten en effecten van de KringloopToets zo concreet en praktijkgericht mogelijk te maken. Het is een analysemodel, dat bovenal moet leiden tot begrip voor de inhoud en begrip voor elkaar. De analyse moet handvatten bieden voor een mogelijk vervolg door de stakeholders zelf. In dat vervolg kan dan de maatschappelijke of politieke discussie gevoerd worden en gezocht worden naar (gemeenschappelijke) oplossingen in beleid en concrete handelingen, op grond van de met de KringloopToets verkregen gedeelde inzichten in en consequenties van maatregelen. De verantwoordelijkheid daarvoor ligt bij de stakeholders en de opdrachtgevers, niet bij de uitvoerder van de KringloopToets. In de casus Mestverwerking is actief onderzocht hoe de aanpak nog praktijkgerichter gemaakt kan worden. Een poging daartoe was het voorstel tot het uitbrengen van een (beleids)advies of een aanzet tot een verbond. Dat gaat duidelijk verder dan de doelstelling van het instrument KringloopToets en is (terugkijkend) niet bevorderlijk voor de kwaliteit van de analyse. Dergelijke acties zijn zaken die na het uitvoeren van de KringloopToets kunnen gebeuren door de stakeholders of opdrachtgever(s); niet tijdens de KringloopToets.

\section{Een werkvorm om tot conclusies te komen}

Daaraan gekoppeld is het punt van de conclusies. Er ontbreekt nog een duidelijke werkvorm om in de workshop tot conclusies te komen. Dat geldt zowel voor eindconclusies als voor tussentijdse conclusies. Wel was deze keer geformuleerd welke inhoudelijke aspecten in de conclusies aan de orde moesten komen:

- Hoe past geen kunstmest c.q. mestverwerking in een circulaire economie, of te wel: wat is de stip aan de horizon voor mestverwerking (visie)

- Wat zijn de verschillende rollen voor de betrokken partijen (beleid)

- Wie onderneemt welke actie (handelingsperspectief)

Na de eerste workshop zijn op deze drie aspecten wel conclusies geformuleerd door de begeleiders die werden gepresenteerd op de tweede bijeenkomst, maar het gezamenlijk formuleren van conclusies is achterwege gebleven. Na de tweede workshop bleek het erg lastig te zijn om tussentijdse conclusies op de drie aspecten te formuleren en aan het einde van de derde workshop zijn geen conclusies geformuleerd. Door het ontbreken van een werkvorm om tot eindconclusies te komen, was niet duidelijk wanneer we klaar waren. In zo'n werkvorm kan dan eventueel ook gezamenlijk worden geconstateerd dat het moeilijk is om heldere conclusies te formuleren. Het gebruiken van de drie niveaus waarop conclusies geformuleerd moeten worden (bijdrage aan circulariteit (visie), rollen voor betrokken partijen (beleid) en wie onderneemt welke actie (handelingsperspectief) is wel voor herhaling vatbaar. Dat moet echter pas ingezet worden als de effecten van een maatregel goed uitgewerkt zijn, omdat anders de neiging bestaat te snel en te veel te focussen op rollen en acties en te weinig tijd te besteden aan gedeelde inzichten over de effecten van de maatregel.

\section{Breder uitdragen van de resultaten}

Het uitvoeren van de KringloopToets kan diverse leereffecten teweegbrengen bij de deelnemers. Maar buiten de kleine groep deelnemers aan de KringloopToets verandert er niets. Grote uitdaging is om te zorgen dat de leereffecten niet enkel optreden bij de deelnemers. Hoe kun je zorgen dat dit verder gedragen wordt? Dit rapport kan daaraan bijdragen, maar er is meer gerichte actie nodig. Het gaat namelijk niet alleen om de uitkomsten. Om maximaal effect te bereiken moeten mensen leren, en dus ervaren; het proces is voor het effect minstens zo belangrijk als de uiteindelijke uitkomsten. hoe neem je een grotere groep mensen daarin mee? Dit is een belangrijk aandachtspunt voor het projectteam, waarover ook gesproken wordt met de Stichting KringloopToets. 


\subsection{2 'Geen kunstmest' versus 'Mestverwerking'}

Met de KringloopToets zijn twee scenario's verkend: in de eerste workshop is gekeken naar een situatie waarin geen kunstmest meer wordt gebruikt in Nederland. In de tweede workshop en deels in de derde is gekeken naar een situatie waarin mestverwerking voor varkensmest voor $100 \%$ verplicht wordt gesteld. Achteraf kunnen we constateren dat de maatregel 'mestverwerking' te sterk aanbodgericht was en daardoor een ander resultaat opleverde op dan de maatregel 'geen kunstmest'. Dat verschil tussen een vraag-gestuurde casus en een aanbod-gestuurde casus is niet tijdig onderkend.

De casus "geen kunstmest" schept een nieuwe situatie waarin helder is hoe de "nieuwe, te onderzoeken, realiteit" er uit ziet. Dat helpt om te analyseren wat de effecten zijn op het sluiten van kringlopen, andere milieuaspecten en economie. Daarmee is deze casus vergelijkbaar met de verkenning in Noord-Brabant waar het ging om het sluiten van regionale kringlopen (Leenstra et al., 2017) en om de verkenning in de werkgroep KringloopToets over het importeren van soja uit OostEuropa (in plaats van Zuid-Amerika) (Leenstra en Vellinga, 2016). Het is helder wat de nieuwe situatie is en de effecten kunnen in beeld worden gebracht. Daardoor leverde de casus "geen kunstmest" een aantal technische inzichten op, die helder maakten of de kringloop beter gesloten wordt dan voorheen.

De tweede casus, "mestverwerking", geeft een activiteit aan, zonder dat een eindbeeld is geschetst wat met de producten gebeurt. Bovendien ligt de casus erg dicht bij de huidige situatie die omgeven is door allerlei onzekerheden en waar (nog) geen helder beeld is waar de mestverwerkingsproducten afgezet kunnen worden. Er zijn twee redenen aan te voeren waardoor deelnemers geen gedeelde inschatting konden maken van de effecten. Enerzijds was de casus "verplichte mestverwerking" door de aanbodgerichte aard nog erg open, het was niet bekend hoe de producten er uitzien, waar ze heen gaan en wat het oplevert. Anderzijds zijn de deelnemers mogelijk te sterk "gevangen" in de huidige patstelling rond mestverwerking waarbij iedereen op elkaar wacht. Als gevolg daarvan leverde de workshop over mestverwerking de behoefte op aan marktontwikkeling en regie en een lijst van vragen, aspecten en problemen waarmee rekening moet worden gehouden als mestverwerking grootschalig wordt aangepakt. Door het aanbod-gerichte karakter kon dus ook niet worden aangegeven of "verplichte mestverwerking" bijdraagt aan het beter sluiten van nutriëntenkringlopen.

Er zijn twee leereffecten te halen uit het contrast tussen de beide casussen:

- $\quad$ Om een goede analyse mogelijk te maken, moet een casus altijd een helder eindbeeld scheppen van een maatregel. Dat moet in termen van "product $X$ wordt niet meer gebruikt of geïmporteerd", "de import van product Y komt uit A in plaats van uit B". Daarmee kan de KringloopToets inzicht geven in het effect van een maatregel, maar nog niet aangeven hoe de maatregel moet worden gerealiseerd.

- Zolang bij alle acties en beleid rond mestverwerking geen helder beeld is van de markt waarop de producten verkocht moeten en kunnen worden, zal het een grote zoektocht blijven. De workshops leren dat bij een helder eindbeeld de deelnemers veel duidelijker hebben wat er moet gebeuren en welke rollen zij en anderen moeten spelen. Om mestverwerking tot een succes te maken, moet een helder eindbeeld worden geformuleerd, waar partijen zich aan willen verbinden.

De conclusie, dat het komen tot vormen van mestverwerking die een optimale bijdrage leveren aan circulariteit, geen technisch maar wel een organisatorisch probleem is, was unaniem. Echter de bereidheid om in technische aspecten radicale stappen te zetten varieerde tussen stakeholders. Dat blijkt bijvoorbeeld in de discussie over het scheiden van feces en urine aan de bron. Dat werd door sommigen als een noodzakelijke stap gezien voor circulariteit (en bijdrage tot oplossing van het mestprobleem), door anderen werd dat als onhaalbaar voor de veehouderijsector gezien. Ook de noodzaak tot regulatie van dieraantallen onafhankelijk van de mate van succes van mestverwerking is en blijft een discussiepunt. 


\section{Afwachten en kiek'n wat't wordt}

Het gebrek aan regie met betrekking tot mestverwerking en de effecten daarvan bij de overheden op verschillende niveaus en overheidsorganisaties werd benadrukt, met name op het vlak van vergunningverlening en regelgeving. Het daadwerkelijk realiseren van mestverwerking als onderdeel van circulariteit kent veel meer samenwerkings- en afstemmingsaspecten. Belangrijk daarin is de noodzaak tot marktonwikkeling voor mestproducten. Dergelijke marktontwikkeling is essentieel, maar alleen mogelijk bij goede en langdurige samenwerking tussen een brede groep stakeholders. Uit de workshops kwamen geen concrete suggesties hoe een dergelijke samenwerking te realiseren. In die zin was deze reeks workshops exemplarisch: als het gaat om mestverwerking blijven de verschillende partijen naar elkaar kijken en op elkaar wachten zonder zich daarover echt uit te spreken en wordt een bal/zwarte piet neergelegd bij de verschillende overheden. 


\subsection{Mestverwerking en het Prisoners Dilemma}

Bart Bremmer, www.innovatiesocioloog.nl.

Het klassieke Prisoner's Dilemma

Het materiaal is ontleend aan "Het Nieuwe Veehouden"(Bremmer et al. 2016). Ad en Bob zijn samen betrokken bij een crimineel vergrijp. Zij worden daarvoor opgepakt en zitten afzonderlijk van elkaar in een cel, in afwachting van hun proces. Tot nu toe hebben ze ontkend betrokken te zijn bij de misdaad. Dan komt de officier van justitie hen bezoeken. Hij heeft een probleem: er is te weinig bewijs om Ad en Bob voor langere tijd op te sluiten en hij komt met het volgende voorstel:

- $\quad$ Als jullie blijven ontkennen, kan ik jullie door gebrek aan bewijs niet langer dan 2 maanden vastzetten.

- $\quad$ Als jullie beiden bekennen, heb ik daarmee het bewijs waar ik naar op zoek ben. Dan gaan jullie beiden 8 maanden de cel in.

- $\quad$ Als één van jullie bekent en de ander ontkent, zal ik degene die bekend heeft vrijlaten, omdat die zo goed heeft meegewerkt. De ander gaat 12 maanden de cel in, omdat er niet alleen bewijs is dat hij schuldig is (de bekentenis van de ander), maar hij ook nog eens heeft gelogen.

Ad en Bob kunnen niet met elkaar overleggen en krijgen niet te horen wat de ander heeft gekozen, tot het moment dat zij zelf gekozen hebben.

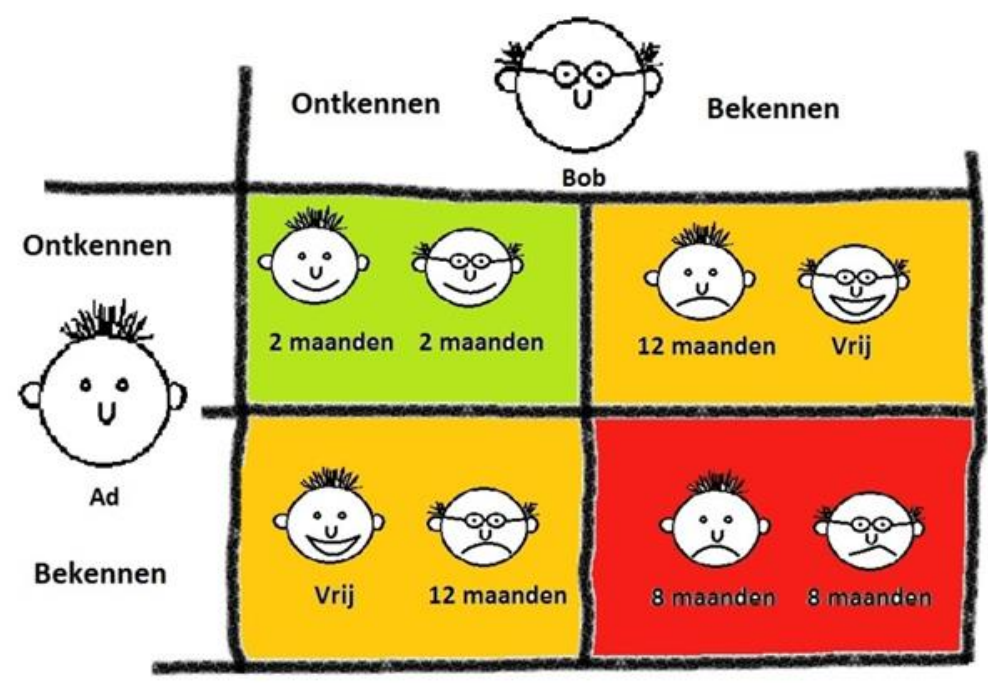

Het zal duidelijk zijn dat het in het belang van beide gevangenen is dat ze beiden ontkennen. In dat geval hoeven ze beiden maar 2 maanden de cel in. Toch ligt het niet voor de hand dat Ad en Bob kiezen voor ontkennen. Voor Ad geldt dat als Bob ontkent, hij kan kiezen tussen 2 maanden cel (ontkennen) en vrijuit gaan (bekennen); bekennen levert hem in dat geval het meeste op. Als Bob bekent, kan Ad kiezen tussen 12 maanden cel (ontkennen) en 8 maanden cel (bekennen); ook in dat geval is bekennen voordeliger. Voor Bob geldt hetzelfde: wat Ad ook kiest, Bob is altijd beter af wanneer hij de misdaad bekent. De keuze, die de officier van justitie de gevangen voorhoudt, stuurt er dus op aan dat beide gevangenen bekennen, terwijl ze een stuk beter af zijn wanneer beiden ontkennen.

Als het gaat om mestverwerking, dan gaat het niet om 2 gevangenen, die de keuze hebben tussen bekennen en ontkennen; het gaat over mestverwerkers A en B, die de keuze hebben tussen wel of niet samenwerken met elkaar. Het levert hen samen het meest op wanneer zij gaan samenwerken; voor beiden heeft dat een duidelijk voordeel ten opzichte van de situatie waarin zij op eigen houtje door ontwikkelen. Maar voor de individuele bedrijven is het nog voordeliger om te profiteren van kennis en inspanningen van de andere partij, zonder daar zelf een open houding tegenover te stellen. Wanneer partij A zich coöperatie opstelt naar partij B, maar partij B doet dat niet terug, dan profiteert $B$ van de inspanningen en kennis van A, maar B houdt zijn eigen inspanningen en kennis voor zichzelf. 
Maar ook als partijen er niet op uit zijn om te profiteren ten koste van de ander, komen zij gemakkelijk tot een suboptimale uitkomst. Als partij B enkel naar zijn eigen keuze kijkt, dan is er de keuze tussen 'individueel' en 'samenwerken'. Ongeacht wat A kiest, B is altijd beter uit door te kiezen voor individueel. Wanneer A kiest voor individueel dan is 0 (uitkomst bij keuze van B voor individueel) te verkiezen boven - (uitkomst bij keuze voor samenwerken). Wanneer A kiest voor samenwerken, dan is ++ (uitkomst bij keuze van B voor individueel) te verkiezen boven + (uitkomst bij keuze voor samenwerken).

Ook wanneer je streeft naar de optimale oplossing voor beiden, zit er nog steeds een belangrijke prikkel in om te kiezen voor individueel. Want niet alleen jij bent beter af wanneer je niet kiest voor samenwerking; dat geldt ook voor de ander. De kans dat de andere partij kiest voor individueel is een heel reële optie. Kiezen voor samenwerken wordt daarmee wel een heel risicovolle onderneming. Dus ook als partijen van goede wil zijn, worden zij door het dilemma weerhouden van samenwerking.

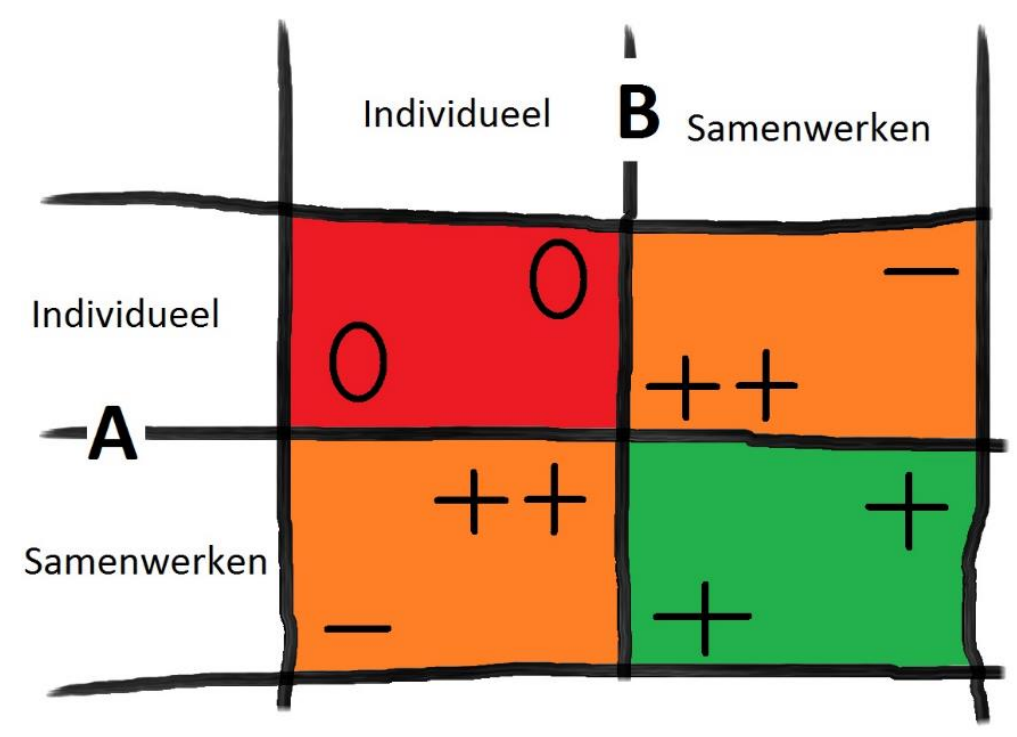

Dit brengt een aantal belangrijke implicaties met zich mee:

- Duidelijk is dat samenwerking lonend is voor het geheel.

- Mar vaak is het voor individuele partijen lucratiever om zelf niet samen te werken, maar wel te profiteren van de coöperatieve houding van anderen.

- $\quad$ En dat hoeft nog niet eens een vooropgezette strategie te zijn; door de onzekerheid over wat de ander gaat doen, worden partijen weerhouden van samenwerken.

- In het oorspronkelijke Prisoner's Dilemma hebben partijen geen contact met elkaar; moeten zij zonder te overleggen een inschatting maken van wat de ander gaat doen. Maar ook wanneer partijen wel de mogelijkheid hebben om te overleggen, verandert dat nog niet automatisch de keuze van partijen. Wanneer je afspraken maakt om samen te werken, wil dat nog niet zeggen dat partijen dat ook gaan doen. Vals spelen loont en er is dus een voortdurende prikkel om af te wijken van de gemaakte afspraken. Die prikkel is nog groter, omdat partijen weten dat ook de andere partij profiteert van vals spelen. Om te voorkomen dat de ander misbruik maakt van jouw open houding, is het veiliger om toch wat minder coöperatief te zijn.

Dit kan anders worden wanneer partijen vaker met elkaar geconfronteerd worden en regelmatig de beslissing moeten nemen of ze met elkaar willen samenwerken. Wanneer een partij met regelmaat niet bereid blijkt om samen te werken, of erger: wanneer een partij een structurele neiging heeft tot valsspelen, dan zullen andere spelers op den duur niet meer met die partij willen samenwerken. Het is overigens ook niet zo dat altijd samenwerken een verstandige keuze is. Wanneer andere spelers hier rationeel op reageren, ontstaat een situatie waarin de ene partij regelmatig misbruik maakt van de andere partij.

Wanneer partijen regelmatig voor de keuze staan om samen te werken, dan blijkt 'tit for tat' (een soort 'oog om oog; tand om tand') de meest effectieve methode te zijn. Bij deze methode streef je naar samenwerking, maar wanneer de andere partij kiest voor individueel, 'straf' je hem door de 
ronde daarop niet samen te werken. Wanneer de andere speler weer begint met samenwerken, ga je daarin mee.

Experimenten tonen aan dat 'tit for tat' op de lange termijn de best haalbare resultaten geeft voor het individu en het collectief. Minstens zo interessant is het feit dat in veel gevallen een tit for tat strategie zich kan verspreiden over een groep. Wanneer 1 partij consequent een tit for tat strategie gebruikt, zullen partijen daar op hen duur de voordelen van inzien en deze ook zelf gaan toepassen.

Tot nu toe is het allemaal vrij theoretisch. We moeten hier een aantal belangrijke elementen uit de praktijk toevoegen:

- In werkelijkheid zijn er niet 2 spelers, maar veel meer. En als partij A en B een samenwerking aangaan, waar zij beiden van profiteren, dan is het heel goed mogelijk dat partij $C$, die niet betrokken is bij die samenwerking, daar wel van profiteert (denk aan het investeren in een certificeringssysteem).

- $\quad$ Als het gaat om mestverwerking dan gaat het over een diversiteit aan thema's en gebieden waarop partijen kunnen samenwerken. Het is dus niet enkel een kwestie van wel of niet samenwerken. Partijen moeten nadenken over op welke thema's ze wel en niet willen samenwerken; op welke basis ze willen samenwerken; en in welke mate ze willen samenwerken.

- In het theoretische model hebben de 2 partijen precies dezelfde uitgangspositie en hebben zij de ander precies hetzelfde te bieden als wat hen wordt geboden. In werkelijkheid is de ene partij 'verder' dan de ander. En partijen moeten afwegen in hoeverre hun techniek gelijkwaardig is aan die van de ander; en in hoeverre hun marktkennis net zoveel waard is als die van de ander. Het Prisoner's Dilemma speelt niet alleen binnen ketenschakels (dus bijvoorbeeld tussen verschillende mestverwerkers), maar juist ook tussen de verschillende ketenschakels. Zo kan het voor de primaire sector een effectieve strategie zijn om af te wachten, totdat anderen hun probleem oplossen.

- De overheid kan in een Prisoner's Dilemma een belangrijke rol vervullen als facilitator of scheidsrechter. Maar in het geval van mestverwerking is de overheid zelf ook een speler. Dat wordt duidelijk wanneer de overheid een te grote rol voor zichzelf zou pakken, en bijvoorbeeld aan marktontwikkeling gaat doen, of direct investeert in infrastructuur. Uiteraard kan dat het geheel verder helpen, maar tegelijkertijd neemt het de prikkel weg bij andere partijen die deze rol effectiever hadden kunnen oppakken.

Het is niet eenvoudig om te bepalen hoe het Prisoner's Dilemma Mestverwerking doorbroken kan worden. Als het wel eenvoudig was, was het waarschijnlijk al wel opgelost. Maar door er met deze bril naar te kijken, krijgen we wel een aantal belangrijke aanwijzingen. Een greep daaruit:

- Het Prisoner's Dilemma leert ons dat samenwerking opeens laten ontstaan een enorme opgave is. Je kunt wel afspraken maken, maar vervolgens moet je ook alle mogelijkheden tot valsspelen ondervangen. Door uit te gaan van een model waarbij je op de lange duur werkt aan samenwerking, ontstaat ruimte voor partijen om een relatie op te bouwen en te werken aan vertrouwen. Door het op die manier in te steken is er veel meer mogelijk.

- $\quad$ Om zo'n samenwerking te laten groeien moet je niet starten met de hete hangijzers. Pluk eerst wat laaghangend fruit, zodat partijen komen tot zichtbare resultaten en enthousiast worden over samenwerking.

- Verandering in organisaties en in systemen begint bij individuen. De samenwerking en het bouwen van vertrouwen moeten dan ook in de eerste plaats gericht zijn op personen. Verschuif de aandacht langzaam van personen naar bedrijven en organisaties.

- Samenwerking zou in zoveel mogelijk gevallen moeten leiden tot exclusieve voordelen, zodat freeriders (degenen die niet mee-investeren) zo weinig mogelijk voordelen hebben.

- Door een regisserende partij kan verandering effectiever worden ingezet, want met een regisseur zijn er meer mogelijkheden om gezamenlijk richting te kiezen en daar ook aan vast te houden. Door regie kunnen de voordelen van samenwerking groeien, zodat de aanzuigende werking van het samenwerkingsverband wordt vergroot.

- $\quad$ Als de samenwerking meer gestructureerd wordt, kun je ook het valsspelen ontmoedigen. Dat betekent duidelijk maken wat wel en niet is toegestaan. En ook het vaststellen van consequenties voor wie zich hier niet aan houdt. Afhankelijk van de overtreding en de situatie kunnen dit concrete straffen zijn, of een 'afstraffing' door reputatieschade. 
Niet alle partijen zullen zich direct aangetrokken voelen tot samenwerken, bijvoorbeeld doordat zij een voorsprong hebben op de rest, of omdat er andere zaken spelen ('oud zeer'). Als er wel een brede samenwerking nodig is, moet je dit als gegeven beschouwen, en partijen de tijd geven om aan te sluiten. 


\section{$7 \quad$ Verwijzingen}

\section{Kunstmest}

https://spotzi.com/nl/kaarten/milieu-en-omgeving/landbouw/kunstmest-verbruik/

https://www.oneworld.nl/atlas/kunstmestgebruik

https://nl.wikipedia.org/wiki/Kunstmest (geen cijfers over verbruik)

http://themasites.pbl.nl/balansvandeleefomgeving/jaargang-2016/themas/landbouw-envoedsel/mest-en-ammoniak (geen cijfers over kunstmestgebruik)

http://www3.lei.wur.nl/agrocenter/Historie\%20van\%20melkvee\%20en\%20mineralen_jan2013.pdf (wel gegevens over kunstmestaanvoer)

http://themasites.pbl.nl/balansvandeleefomgeving/jaargang-2012/integraal-stikstof/stikstofoverschotvan-de-landbouwgrond-nederland-en-eu (stikstofgift uit kunstmest en dierlijke mest)

\section{Benutting van $\mathbf{N}$ en $\mathbf{P}$ in de landbouw}

https://www.cbs.nl/NR/rdonlyres/66F168B9-7628-4FDE-AD09-

20BA7CF31364/0/2012benuttingstikstoffosforlandbouwart.pdf

\section{P stromen in Nederland}

http://edepot.wur.nl/357172

http://edepot.wur.nl/353317 P-stromen V-Focus

http://www.brabantsemilieufederatie.nl/friksbeheer/wp-content/uploads/2017/02/rapportvolksgezondheid_veehouderij_pdf.pdf

\section{Veehouderij en gezondheid}

http://www.rivm.nl/Onderwerpen/V/Veehouderij_en_gezondheid/Onderzoek_veehouderij_en_gezondh eid_omwonenden_VGO

http://www.kennisplatformveehouderij.nl/ 


\section{Literatuur}

Baltussen, JJM en Jans H (2016) Titel: Toetsingskader humane gezondheidsaspecten met betrekking tot mestverwerking/-bewerking. Uitgave: Provincie Noord-Brabant.

Bremmer, B., H. Kortstee, J. Vierstra, Y. van Wichen, Kristel van Veen en Ernest van de Boezem, 2016. Het Nieuwe Veehouden mogelijk maken; Zoeken naar ruimte voor verduurzaming in de veehouderij. Wageningen, LEI Wageningen UR (University \& Research centre), LEI Rapport 2016-002. 52 pp.

Giepmans, R. R. Nijdam, M. Scholtes, H van Breugel, M.L. van Bommel, 2017. Handreiking veehouderij en volksgezondheid. BPO Speerpunt transitie Zorgvuldige veehouderij. Definitieve versie 3 maart 2016, 58 pp.

Lesschen, J.P., I. Staritsky en G.L. Velthof, 2011. Verkenning grootschalige toepassing van mineralenconcentraten in Nederland; Effecten op nutriëntenstromen en emissies. Wageningen, Alterra, rapport 2247. $110 \mathrm{blz}$.

Ministerie van Infrastructuur en Milieu, ministerie van Economische zaken, 2016. Nederland circulair in 2050, 72 pp. www.rijksoverheid.nl/circulaire-economie.

Schröder, J.J., R. P. O. Schulte, R. E. Creamer, A. Delgado, J. Van Leeuwen, T. Lehtinen, M. Rutgers, H. Spiegel, J. Staes, G. T_Oth, D. P. Wall (2016). The elusive role of soil quality in nutrient cycling: a review. Soil Use and management 32: 476 - 486. Doi: 10.1111/sum.12288.

Schoumans, O.F., P.W. Blokland, P.Cleij, P. groenendijk, T.J. de Koeijer, H.H. Luesink, L.V. Renaud, J. van den Roovaart, 2017. Ex-ante evaluatie van de mestmarkt en milieukwaliteit; Evaluatie van de meststoffenwet 2016. Wageningen Environmental Research, rapport 2785, 94 blz.

Smit, A.L.; Middelkoop, J.C. van; Dijk, W. van; Reuler, H. van (2015). A substance flow analysis of phosphorus in the food production, processing and consumption system of the Netherlands. Nutrient Cycling in Agroecosystems 103 (1). - p. 1 - 13.

Timmerman, M., (2016). Ontwikkeling van de mestverwerkingscapaciteit; Achtergronddocument bij rapportage Ex post evaluatie Meststoffenwet. Wageningen Livestock Research, Rapport 473.

Velthof G. T. Koeijer, J.J. Schröder, M. Timmerman, A Hooijboer, J. Rozemeijer, C van Bruggen en P. Groenendijk, 2017. Effecten van het mestbeleid op landbouw en milieu; Beantwoording van de ex-post vragen in het kader van de evaluatie van de Meststoffenwet. Wageningen Environmental Research, rapport 2782. 140 blz. 

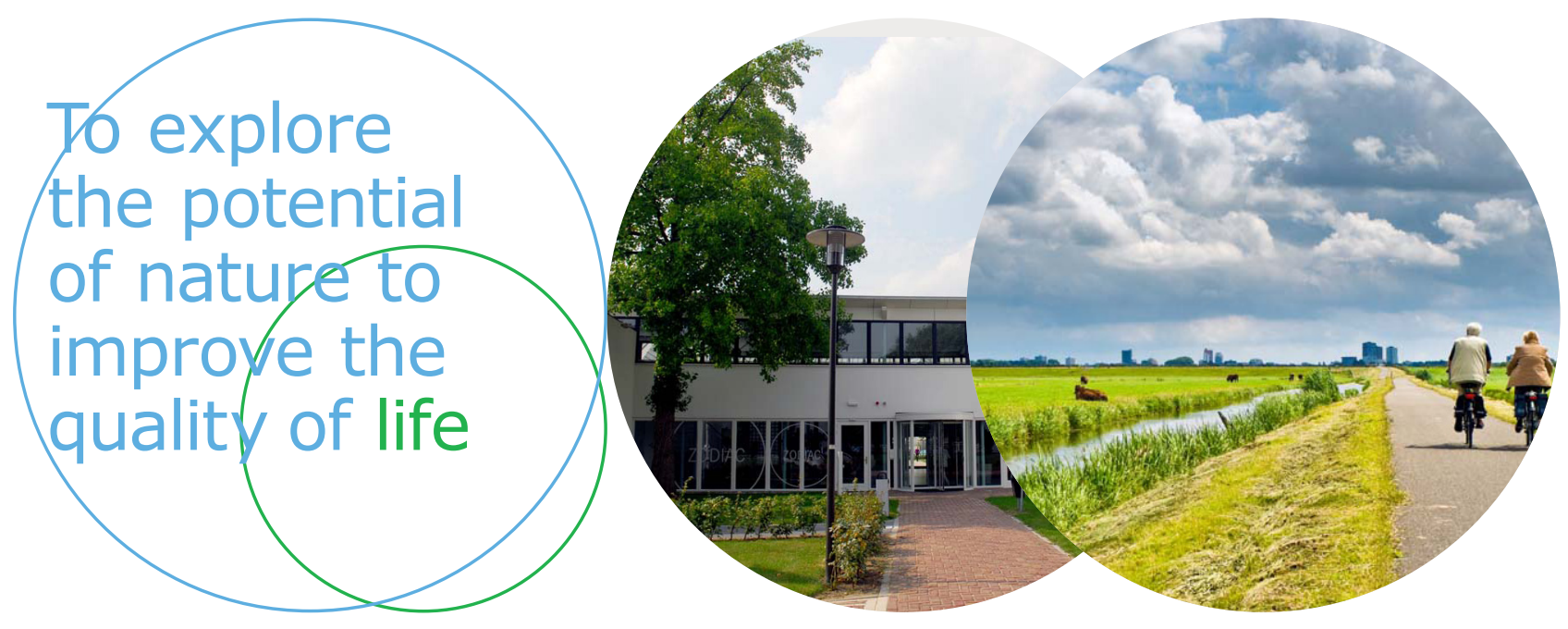

Wageningen Livestock Research Postbus 338

Wageningen Livestock Research ontwikkelt kennis voor een zorgvuldige en 6700 AH Wageningen

T 0317483953

renderende veehouderij, vertaalt deze naar praktijkgerichte oplossingen en innovaties, en zorgt voor doorstroming van deze kennis. Onze wetenschappelijke

E info.livestockresearch@wur.nl www.wur.nl/ livestock-research kennis op het gebied van veehouderijsystemen en van voeding, genetica, welzijn en milieu-impact van landbouwhuisdieren integreren we, samen met onze klanten, tot veehouderijconcepten voor de $21 \mathrm{e}$ eeuw.

De missie van Wageningen University \& Research is 'To explore the potential of nature to improve the quality of life'. Binnen Wageningen University \& Research bundelen 9 gespecialiseerde onderzoeksinstituten van Stichting Wageningen Research en Wageningen University hun krachten om bij te dragen aan de oplossing van belangrijke vragen in het domein van gezonde voeding en leefomgeving. Met ongeveer 30 vestigingen, 6.500 medewerkers en 10.000 studenten behoort Wageningen University \& Research wereldwijd tot de aansprekende kennisinstellingen binnen haar domein. De integrale benadering van de vraagstukken en de samenwerking tussen verschillende disciplines vormen het hart van de unieke Wageningen aanpak. 